\title{
IIC JOURNAL OF INTERNATIONAL legal COMMUNICATION
}

vol. 2 No. 1 (October 2021)

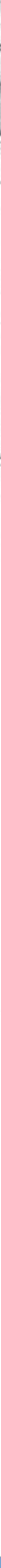




\section{EDITORIAL BOARD}

\section{Editor-in-Chief:}

Joanna Osiejewicz, University of Warsaw

\section{Associate Editors:}

Agnieszka Andrychowicz-Trojanowska, University of Warsaw Anna Bonek, University of Warsaw

Izabela Gawłowicz, University of Zielona Gora

\section{Editorial Board Members:}

Rainer Arnold, University of Regensburg, Germany Janina Ciechanowicz-McLean, University of Gdansk, Poland Roberto Cippitani, University of Perugia, Italy Marcelo Figueiredo, Pontifícia Universidade Católica de São Paulo, Brasil Sambor Grucza, University of Warsaw, Poland Cristina Hermida del Llano, King Juan Carlos University in Madrid, Spain Uwe Kischel, University of Greifswald, Germany Andrew Massey, King's College London, United Kingdom Adam Niewiadomski, University of Warsaw, Poland Daniel-Mihail Şandru, University of Bucharest, Romania Iryna Sopilko, National Aviation University, Ukraine Marc-Philippe Weller, Heidelberg University, Germany Roman Wieruszewski, Polish Academy of Sciences, Poland Luping Zang, China University of Political Science and Law in Beijing, China Sławomir Żółtek, University of Warsaw, Poland 


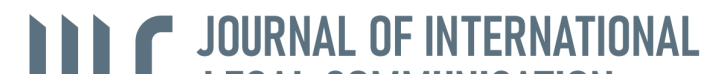 LEGAL COMMUNICATION}

vol. 2 No. 1

October 2021

\section{FOREWORD}

The first thematic block in this issue of the Journal of International Legal Communication is structured around civil law. Ramona Duminică devoted her study to theoretical aspects related to legislation, codification and presentation of the rules on the style and language of normative acts in Romania. She focuses on exemplification of legal norms in the Romanian Civil Code, whose intelligibility is questioned. Izabela Gawłowicz and Piotr Sobański analyze selected judgments of the Polish family courts, looking for a legal vision of parental authority in Polish law and for the optimal standard of exercising it in practice.

The second thematic section deals with public authority. Zhanna A. Kovalenko claims that the legal nature of the guarantees on public control and the specifications of their essence largely depend upon the kind of content that is embedded into the concept of the law. She presents the opinion that the most accurate way to reveal the nature of legal guarantees seems possible with the help of the key concept of "legal means". Eugen Chelaru and Andra Puran point to the necessity of a constitutional regulation of the status of minorities, based on the Constitution of Romania. Ondřej Preuss elaborates on the understanding of the notions of the constitutional identity, the material core of a constitution and unamendable elements of a constitution (eternity clauses) and on the concept of essential elements of a democratic state governed by the rule of law as reflected in the practice of the Czech Constitutional Court.

The third section is devoted to educational issues. Svitlana Shevchuk, Volodymyr Kulishov and Tetiana Shchypska present the main approaches to the development of professional competence of a teacher of the system of vocational and professional higher education. They point specifically to teachers' ability to modern educational and methodological activities, which involves designing classes based on a competency approach, the use of innovative educational

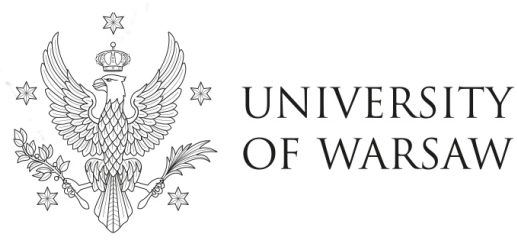


technologies, and the introduction of integrated learning in the system of vocational education. YuliyaVolynets, Nadiia Stadnik and Tetiana Panchenko identify the components, criteria, indicators and describe the levels of leadership development of future leaders of preschool education. They define basic concepts of the problem: leader, leadership, professional qualities of the leader, leadership qualities of future heads of preschool educational institutions, and pedagogical conditions of formation of leadership qualities.

The article section ends with the paper by Joanna Osiejewicz, who presents the cognitive theory of metaphor and a constitutive nature of metaphor within our analytical framework. She highlights the practical implementation of the theory in the field of legal communication, focusing on metaphorical construction of legal concepts, visualization of legal information and metaphorical legal reasoning.

Volume 2 closes the JILC Young Writer's Corner with one article. Julia Pisulińska attempts to indicate the research on the field of legal communication as based on juridical language and legal language. She pays attention to the problem of communicativeness, the text as a part of legal communication, the issue of terminology, and the correctness of language of law and legal translation. She draws valuable conclusions noticing the general need of expanding knowledge specifically in relation to language and law.

On behalf of the JILC Editorial Board, I wish you a pleasant reading.

Joanna Osiejewicz

Editor-in-Chief 


\section{OPEN ACCESS}

This content is licensed under a Creative Commons Attribution 4.0 International License, which permits use, sharing, adaptation, distribution and reproduction in any medium or format, as long as you give appropriate credit to the original author(s) and the source, provide a link to the Creative Commons licence, and indicate if changes were made. The images or other third party material in this book are included in the article's Creative Commons licence, unless indicated otherwise in a credit line to the material. If material is not included in the article's Creative Commons licence and your intended use is not permitted by statutory regulation or exceeds the permitted use, you will need to obtain permission directly from the copyright holder. To view a copy of this licence, visit http://creativecommons.org/licenses/by/4.0/.

(C) 2021 University of Warsaw

Publisher:

University of Warsaw

Krakowskie Przedmieście 26/28

00-927 Warszawa

Poland

jilc@uw.edu.pl

\section{PUBLISHER'S NOTE:}

The opinions expressed in the published articles are the sole responsibility of the authors and do not reflect the opinion of the editors or members of the editorial board.

JILC remains neutral with regard to jurisdictional claims in published maps and institutional affiliations

Manager:

E-SCIENCE SPACE sp. z o. o.

Szczęsna 26

02-454 Warszawa

Poland

KRS: 0000870645

NIP: 5223193151

info@e-science.space 


\section{CONTENTS}

Style and Language in Writing Laws. The Situation of the Romanian Civil Code Ramona Duminică

The Communicative Aspects of the Settlements of the Parent - Child Contacts after the Divorce (Polish Case-Law and the Indication to ECHR Case-Law)

Izabela Gawłowicz, Piotr Sobański

Legal Guarantees on Public Control

Zhanna A. Kovalenko

Constitutional Status of National Minorities in Romania

Eugen Chelaru, Andra Puran

A Democratic State Governed by the Rule of Law - The Constitutional Identity of the Czech Republic

Ondřej Preuss

Vectors of Development of Educational and Methodological

Competence of the Modern Teacher in the Conditions of Modernization

of Vocational Education of Ukraine

Svitlana Shevchuk, Volodymyr Kulishov, Tetiana Shchypska

Pedagogical Conditions for the Formation of Leadership Qualities of

Future Heads of Preschool Education Institutions

Yuliya Volynets, Nadiia Stadnik, Tetiana Panchenko

Metaphor in Legal Communication

Joanna Osiejewicz

\section{Young Writers' Corner}

Linguistics in Legal Communication: Language, Communication, Text, Law

Julia Pisulińska

\section{Academia}

13th International Symposium on Bilingualism (ISB13),

9-14 July 2021, Warsaw, Poland

Magda Żelazowska-Sobczyk, Piotr Romanowski

International Interdisciplinary Symposium on Art,

Science and Technology MEDEA, 2011-2021 


\title{
STYLE AND LANGUAGE IN WRITING LAWS. THE SITUATION OF THE ROMANIAN CIVIL CODE
}

\author{
Ramona Duminică, \\ University of Pitești, Lecturer, PhD, \\ Faculty of Economic Sciences and Law, Bld. Republicii, no. 71, \\ Pitesti, Romania \\ https://orcid.org/0000-0002-3416-2329 \\ *duminica.ramona@gmail.com
}

\begin{abstract}
The debates on the drafting of laws in general and codes in particular are not recent but are an eternal topic of political and legal science, which is returning with increasing force. The same topic, but each time approached for different reasons and in different contexts, which gives it a permanent topicality.

The current scientific approach addresses the traditional issue of rules regarding the style and language of drafting a normative act. The analysis does not claim an exhaustive study in the field, but represents a call for reflection, the purpose being mainly to analyze, 10 years after the entry into force of the new Romanian Civil Code, to what extent it manages to meet accessibility requirements and intelligibility. In order to be able to truly know an institution or a legal phenomenon, in order to be able to identify its vices and qualities, it is necessary to first clarify the concept itself and establish its foundations. Therefore, the first part of the study is devoted to the theoretical aspects related to legislation, codification and presentation of the rules on the style and language of normative acts. The second part of the study focuses on highlighting, by way of example, some legal norms in the current Civil Code whose intelligibility is questioned.
\end{abstract}

Keywords: enactment, drafting the law, style, normative language, codification, intelligibility of the law

\section{INTRODUCTION}

Starting from the fact that a Civil Code represents one of the fundamental normative acts of any legal order and taking into account that it is a law that regulates the most important values of a society, such as family relations, patrimony, property, movement of goods, etc., it is necessary to be characterized by stability and accessibility.

In order to ensure these objectives, it is necessary for the normative act to be drafted in a specific legal language, concise, sober, clear and precise style that excludes any ambiguity, with strict observance of grammatical and spelling rules.

The clarity and precision of the normative style is achieved by the appropriate use of words in relation to their usual meaning and by the way they are arranged in sentences and phrases, with strict observance of grammatical rules. Polysemy creates the risk of 
misunderstanding the legal message, it contradicts the requirement of clear and precise expression of legal concepts.

Unfortunately, despite all the recommendations of specialists in law, specific legislation and guidelines for its implementation, in legislative practice it is found the use of words with a certain meaning in a normative act, and in those amending or related definitions they have a different meaning or, worse, other words with a similar meaning are used. All these lead to the appearance of contradictions between the norms included in the same normative act. Such examples are also found in the new Romanian Civil Code, and some of them are the subject of this study.

The unintelligibility of a law or a set of laws impairs its effectiveness, which is reflected, in particular, in the possibility of being understood by the one who has to respect it and the one who has to apply it. Today, the citizen can understand the law only through the lawyer. He, in turn, often faces the problem of the impossibility of deciphering its meaning due to the complicated, ambiguous style in which it is written. The complexity of decision-making, the complicated procedure for drafting the law and not all the established rules and tools of law available to the lawyer-draftsman do not always ensure the guarantee of obtaining a good law (Duminică, 2012).

The law is the product of a long journey during which many actors intervene, with different titles, such as: the Prime Minister, ministers, the president or most often their collaborators, trade unions or professional organizations, etc. The project is subject to arbitration, consultations, debates. It is necessary to take into account the international and union law and also to consider the consequences of a possible review by the constitutional judge. Beyond the choices of common devaluers, a result will be obtained without verticality, confusing. For the purpose of conciliation, Parliament could also choose an ambiguous wording (Mathieu, 2010).

All these debates, although topical, are strangely very old, recurring throughout history. The same problem always appears, it is constantly changing and it does not stop reappearing: "it is an endless cycle, a sign of the inherent imperfection of any law and of continuous effort, but inefficient in ending it: the myth of the golden age, that of simple law and clear, a timeless myth, reminiscent of a distant, legendary past and sends to a hypothetical and always precarious bright future" (Malaurie, 2005).

Whether we refer to the Romanian, Italian, Spanish, Polish or French legislation, the problem is the same for all, and the countless reproaches addressed to the wording of the law, its vices are always and everywhere the same: unintelligibility, inefficiency, inadaptability.

\section{PURPOSE, MATERIALS AND METHODS}

The present study does not aim to make a general theory of the language and style of drafting a normative act, but urges a reflection on the role and functionality of the current Romanian Civil Code, raising a question to which it tries to find a possible answer: Are the clarity and precision of language and style objectives that are impossible to achieve in writing a code?

In order to achieve this goal, several methods of scientific research are combined, respectively: the logical, historical, and grammatical method, the paper falling within 
the scope of the general theory of civil law, the topic being approached mainly from the perspective of this discipline. However, the way in which the subject is treated gives the study an interdisciplinary character reflected by documentary sources belonging to various fields: general theory of law, legal sociology, constitutional law, legal linguistics, history of law, political science etc. Beyond the traditional bibliographic documentation, the paper is also based on the direct documentation through which the analysis of the language and style in which the current Civil Code was written.

\section{RESULTS AND DISCUSSION}

\section{The enactment - science, technique, art}

Towards the end of the 1960s, with the development of the social sciences in general and of legal sociology and of political science in particular, the static view of legislation limited only to the formal adoption of laws changed radically. Lawyers are becoming aware of the dynamic nature of the law.

In this context, there are concerns about the birth and development of a true science of legislation. Its essential attribution was to find coherent answers to essential questions aimed at how social, political, economic, etc. issues can be regulated through legal norms or how social reality can be influenced in a certain way through norms.

Thus, the notion of legislation began to take shape as an "active regulation", with a welldefined purpose oriented towards the idea of justice, and the effective methods of legislation were drawn, based on the "model of conscious individual actions". The legislative technique had only an auxiliary, secondary function, being considered only the concrete way to achieve the proposed objectives. Starting from here, nowadays, the legislation is considered both a science and a technique, even an art (Zlătescu, 1995).

The science of legislation appears as interdisciplinary, bringing together not only specific areas of law, but also disciplines such as sociology, political science, public policy, etc. Legislation is considered and treated as a "process", emphasizing its dynamic nature, seeking to take into account what happens before and after the decisions of the formal legislator, i.e. the body that has a democratic legitimacy. The science of legislation is inspired by papers and theories on decision-making in general and on political decision-making in particular (Pătulea, 2010).

It is said that legislation is at the same time not only science, but also technique and Art It is the art of negotiation in order to express the political will as the will of the people, representing the art of harmonizing the demands of daily life with the possibility of achieving these requirements. The elaboration of the law is the result of the compromises between desideratum and reality. At the same time, it is technical because in the construction of the law strict rules are observed regarding its form, the elaboration and adoption procedure and, last but not least, the rigor of the legal language and style is observed.

\section{Codification - a superior form of elaboration and systematization of law}

Regarding the codification, it is a superior form of the systematization of the law and one of the most important factors of legal security.

Reviewing the definitions given to codification over time, it is observed that there are 
two categories: traditional definitions, according to which the codification presupposes "the inclusion in a code (normative act with legal force of law) of legal norms belonging to the same branch of law, involving a rich activity of the legislator, of complex processing of all normative material, of removal of obsolete, obsolete norms (including habits), of filling gaps, of legislative renewal (introduction of new norms, required by the evolution of social relations), of logical ordering of the normative material and of the use of some modern means of legislative technique (the choice of the way of regulation, of the external form of regulation, of the use of the adequate means of conceptualization)" (Popa, 2020) and the proposed by specialists in formal law, according to which codification "is that superior form of legislative systematization, consisting in rare (integration) in a single act, of large scale, of several regulations in a certain field or branch of law" (Popescu\&Ţăndăreanu, 2003).

In the sense of the second category of definitions are also the provisions of Art 18 of Law $24 / 2000$ on the norms of legislative technique for the elaboration of normative acts which stipulate that "in order to systematize and concentrate the legislation, the regulations in a certain field or in a certain branch of law, subordinated to common principles, may be reunited - a unitary structure, in the form of codes".

Therefore, codification is both a form of systematization and an important component of the legislative activity, which is why the codification act (adoption of the code) is the exclusive competence of the Parliament.

Although codification is sometimes seen as a simple remedy for legislative inflation and the dispersion of sources, in which case the code itself risks being an excess, codification is the expression of a rational right based on a logical and systematic method that must allow the establishment of general principles and to provide concrete and intelligible consequences for the individual (Nadaud, 2008).

Codification is more than a sum of laws; it reflects the spirit of a system as a whole. Also, if the codification process can restore its traditional values to the law, a bright future awaits it, otherwise it will suffer the same discredit developing the predictions made some time ago: "Today, codes only suffocate us with their formulations..." (Oppetit, 1998).

From the perspective of our study, we argue that codification could remedy a number of major defects of the law and implicitly of the modern state: proliferation, accumulation, unintelligibility of rules and legislative instability. As such, codification aims to ensure better accessibility of legislation, in accordance with the principle of legal certainty, allowing the creation of a single document in a field of law, which brings together the scattered rules to make them coherent and accessible, based on a plan coherent. This plan makes it possible to clarify the rules on codification, to update them by repealing obsolete, incompatible or unconstitutional texts, and to adapt them to Union or international rules.

In the Romanian law, although there were codes before 1864 (for example, the Caragea Code and the Calimach Code in 1831), still in the history of our law, the Romanian Civil Code, elaborated in 1864 during the reign of Alexandru Ioan Cuza and entered effective December 1,1865 . The value of this code is indisputable, as it includes all the rules and institutions of private law. This value is given not only by its content, but also by the form of its wording and the language used. Basically, in Romania only after the adoption of 
this code can we talk about the birth of a legal language (Predescu, 2006). In those times, neologisms were used in its drafting and foreign terms in the legal field were adapted to the Romanian language, given that the main source of its conception was the French Civil Code of 1804. Finally, it resulted in a modern and accessible normative act, written in a simple and precise style.

This code remains in history as a model of regulation, a proven aspect and the duration of its application, respectively from 1865 until 2011 when the new Romanian Civil Code came into force. Although during the communist regime, important parts of the code were repealed, became inapplicable, were supplemented, amended, yet it survived those times, and after the Revolution of December 1989, regained its place as a basic normative act of the Romanian civil law.

The transformations undergone by the Romanian society in the years following the revolution, the integration in the European Union, the assumption of the obligation of legislative harmonization, as well as the impossibility of the 1864 code to regulate the new social, cultural, technical-scientific and economic values appeared as a result of natural evolution of the social realities in our country are some considerations that imposed the need to elaborate a new Civil Code. Therefore, in 2009, after the long efforts of Romanian lawyers to modernize the civil law, the Romanian Parliament adopted by Law no. 287/2009 the new Civil Code, entered into force on October 1, 2011. It was intended that this new code be a modern tool for regulating the fundamental aspects of individual and social existence, including all provisions regarding persons, family relations, relations trade relations and even private international law relations, thus promoting a monistic conception in the regulation of private law relations. This concept is also promoted by other European countries such as France, Switzerland, the Netherlands or Italy. As stated in the explanatory memorandum, one of the main sources of inspiration or one of the models used for the elaboration of the new Romanian Civil Code is the Civil Code of the province of Quebec in Canada. Although the Quebecoise Civil Code is indeed the most recent of the codes of the other civil law states and extremely well elaborated, being the result of over 50 years of intense work, we still consider this option of the Romanian legislator uninspired, based primarily on the novelty argument because, as we have already argued in other studies (Tabacu\&Duminică, 2012), it is obvious that this model does not include the regulations that must be found in the case of a unitary state, as is the case in Romania. While the legislation of a province is, of course, complemented by existing legislation at the federal level, the situation is not the same for unitary states.

Moreover, the mere copying of provisions, as certain institutions are sometimes illustrated in the new Civil Code, does not amount to a real codification activity that should start from a solid, scientific research of the social realities existing at the level of a society. There is a risk that the way in which certain institutions are regulated may prove not to correspond to the environment where their implementation is desired, which may lead to the lack of finality of those rules. If indeed the Civil Code of 1864, considered to be a faithful copy of Napoleon's civil code, proved its effectiveness over time, it remains to be seen whether such an approach to codification is equally effective in the current society. 


\section{Clarity and precision of language and style - objectives impossible to achieve in drafting a normative act? The situation of the Romanian Civil Code}

Both history and linguistics attest to the fact that the intelligibility of laws is a goal that has never been achieved but has always been pursued.

Two examples of this constant are sufficient to prove this: the Roman Law of the Twelve Tables and the Drafting of Customs in France. In the $5^{\text {th }}$ century BC, the plebs fought and finally obtained the drafting and publication of the Law of the Twelve Tables, necessary to defeat the arbitrary omnipotence of the patrician priests. One notices here the complex importance of understanding the law, which is not only a technical reality, a knowledge of the law, a certainty and a simplification characteristic of it, but a political problem above all. The emancipation of the plebs thanks to the Law of the Twelve Tables was a remarkable event and probably one of the most important in the history of Rome.

However, like any normative act, the Law of the Twelve Tables was eroded by the passage of time and a huge body of norms was slowly and inexorably added to it, turning it into a difficult law to understand, so much so that in the $6^{\text {th }}$ century AD. Justinian undertook the drafting of the Digests, which he intensely promoted: "Both the rich and the poor can buy [the laws] for a few pennies and obtain for nothing the essence of wisdom". Again, as in the case of the Law of the Twelve Tables, the simplification of laws is part of a political plan to make the law more accessible to the people. Immediately, criticism also appeared, Montesquieu pointing out that "The Law of the Twelve Tables is a model of precision; the children learned it by he Art Justinian's new laws are so vague that they needed to be shortened". The same happened in the $15^{\text {th }}$ and $16^{\text {th }}$ centuries in France when King Charles VII ordered the customs to be drafted by the ordinance of Montil-lès-Tours, because their existence could not be proved. After the customs were drafted, history repeated itself: the law expanded, then it was simplified by the Civil Code, then it developed again. The Twelve Tables, the efforts of Justinian and Charles VII, the Civil Code, the codification of constant law, all these examples show us that the law always becomes unintelligible (Malaurie, 2005).

The history of law therefore easily demonstrates that the simplification of legal norms is a desideratum that seems intangible, but to which it must constantly strive. In contemporary society, doctrinal debates (Deleanu, 2011; Duminică, 2012) are just as intense. Recently, it was substantiated in a specialized paper that "the effectiveness of the law is closely related to its comprehensibility. The law is understandable to the recipient only if it serves their communicative needs. The coherence of the law is one of the conditions of the intelligible law" (Osiejewicz, 2020).

Therefore, through the combined effort of doctrinaires and practitioners, this universal and eternal aspiration of the intelligibility of the law has today become an obligation for the legislator and a "human right".

\subsection{The language of the legislator and the style of drafting normative acts}

In the activity of elaboration of the normative acts, after the establishment of the legal concepts and, mainly of the legal rules, follows the transposition in words, the effective drafting of the law. At this stage, it is essential to identify the word and the clear, coherent, simple formula for expressing the rules of law. The word and the formula of expression thus 
constitute the basic tools, absolutely necessary for the communication of the notions, norms and legal reasonings.

Starting with the theological phase of the law, passing through Antiquity, through Roman law and reaching contemporaneity, the veneration of the word was maintained, the word reflecting the essence of the act, people believing in the law, and for most the law meaning word. From this perspective, the normative act expresses the word of the legislator, through which the rights and obligations of the citizens are brought to the knowledge of the citizens. Given the addressee of the rule, it is necessary that the drafting of the legislative text be subordinated to the use of words with wide circulation, accessible to the whole population, the use of words in their proper sense, and the use of technical terms should refer only to those regulations which cannot find a correspondent in the current language.

In general, the drafting of the law involves the transposition in written text of the ideas that make up the substance of the regulation. The correct wording of the text is a fundamental condition for maintaining - in the application activity - the authenticity of the intended concept and solutions. The text of the law is considered to be "the outer garment of the will of the legislator", the form of expression of a thought, and a thought can be received correctly only through a clear and precise message. Between the background of the law and its form of textual expression there is a dialectical relationship, a relationship of mutual involvement. The text is the expression of the legislator's thought, and the background, in turn, cannot exist outside an expression, the text of the law being the means of communication that expresses the will of the legislator (Mrejeru, 1979).

As a rule, as it results from the above, it is considered that the legislative language is the expression of the legislator's thinking as if it is or could be contained or reflected entirely in the language. Or, thinking is always much deeper than language, and the word, no matter how well chosen, cannot have the brilliance of thought.

Legal language is not only an external formula of the legislator's decisions, but it is a structured language, with its internal dynamics, with its own content and form. The problem of language that the legislator has to solve is thus extremely complex. The possibility of translating the nuances of thought into a clear text that aims to be applied by all in the same way seems an almost unattainable goal or extremely difficult to achieve. In order to obtain this desideratum, the rules of legal linguistics are usually used.

Thus, linguists analyzed the discourse as that of a single author "ME", pronounced in a non-neutral place "HERE", currently pronounced "NOW". However, the keys to the analysis of discourse considered as the expression of the thinking of the one who utters it, which contemporary linguistics provides us, are partially unsuited to the legislative discourse (Richevaux, 2002).

The conditions for drafting the legislative discourse do not allow the application of this scheme and explain, in large part, the difficulties encountered by a text of law, faced with a practice that does not always receive the same message as the one issued by the legislator who drafted the law to be applied. First of all, the legislative discourse is related to a pluralistic thinking, there are several authors with different thoughts who do not always meet and who often do not even really try this. Legislative activity is often presented as hurdle-race in which everyone seeks more to prevail than to participate in the elaboration 
of a joint work. This makes the synthesis that will have to result from the deliberation more difficult to obtain and greatly relativizes the uniqueness of the thinking of the legislator about which the jurists discuss.

As such, referring to the conditions of drafting the law, the thinking of the legislator becomes plural. It is the result of a deliberation, which often takes the form of confrontations, which damages the uniqueness of the discourse, so that sometimes one can speak of a pluripaternity of the law, which does not allow to reach automatically a text characterized by clarity, although one of the virtues of the parliamentary debate is to allow the improvement of the technical quality of the text precisely due to the debate (Richevaux, 2002).

These are just a few reasons why today's law is characterized by instability and unintelligibility.

Distinct from language, in the specialized literature is treated the normative style defined as "the totality of the artifices and the modalities that are the basis for the drafting of normative acts" (Vida, 2012).

Although there were opinions according to which there would be a plurality of styles, one could thus speak a style specific to private-civil, commercial, private international law - with certain particularities in the normative acts regarding labor relations and social protection, another style in criminal law, and finally, another in administrative law (Zlătescu, 1995), as far as we are concerned, we consider, taking into account the provisions of Art 36 of Law 24/2000 on the norms of legislative technique for the elaboration of normative acts suggestively entitled - "the style of normative acts" - that we are in the presence of a single style proper to normative acts, regardless of the name (law, code, ordinance or Government decision).

\subsection{Legal provisions regarding the style and language of drafting a normative act and their observance in drafting the Romanian Civil Code}

Law 24/2000 dedicates chapter IV, entitled "Drafting of normative acts", to the rules that must be observed by the drafter of the law in the elaboration of any normative act. Thus, Art 35 stipulates that it is necessary to ensure a logical succession of the envisaged legislative solutions and to achieve an internal harmony of the normative act so that the drafting of the draft text is preceded by drawing up a plan for grouping ideas according to the connections and the natural relationship between them, within the general conception of regulation.

Regarding the drafting style, the Romanian legislator expressly provides that normative acts must be drafted in a specific normative language and legal, concise, sober, clear and precise style, which excludes any ambiguity, with strict observance of grammatical and spelling rules. At the same time, it is forbidden to use of neologisms, if there is a synonym that is widespread in Romanian. In cases where the use of foreign terms and expressions is required, their correspondent in Romanian will join, as appropriate. The writing of the texts is done by using the words in their current meaning from the modern Romanian language, avoiding regionalisms. The wording is subject to the desire of the recipients to easily understand the text.

Also, Art 37 of the same law establishes that in "normative language the same notions are expressed only by the same terms. In the event that a notion or term is not established or 
may have different meanings, its meaning in context is established by the normative act that establishes them, within the general provisions or in an annex intended for the lexicon, and becomes mandatory for normative acts from the same matter".

Regarding the expression of the normative content, the legislator mentions the need for the text of the articles to have a dispositive character and to present the established norm without explanations or justifications. Usually, in drafting the normative act, verbs are used in the present tense, the affirmative form, to emphasize the imperative nature of that provision, and the use of explanations by interpretative rules is allowed only insofar as they are strictly necessary for understanding the text.

Last but not least, the legislative text must be clearly, fluently and intelligibly formulated, without syntactic difficulties and obscure or equivocal passages. The use of emotionally charged terms is not allowed. The form and aesthetics of the expression must not prejudice the legal style, the precision and the clarity of the provisions.

Although these rules exist and efforts have been made to improve the language and normative style, in practice we still quite often find unintelligible provisions, rules that give rise to contradictory interpretations, unclear and therefore lacking much desired accessibility. Unfortunately, we also find such examples in the current Civil Code.

It is true that the legislator of the Romanian Civil Code in force has made real progress in terms of language and style used, removed the archaisms that made it difficult to understand the texts of the previous code, but on the other hand, by redefining certain traditional institutions of civil law, has again fallen into the trap of lack of clarity. Such an example is the definition given to a fundamental institution of civil law, the property, a definition that has a predominantly technical character, difficult to understand for the simple litigant, the Code establishing by Art 555 Para 1 that "private property is the right of the owner to own, use and dispose of an asset exclusively, absolutely and perpetually, within the limits established by law".

Although the legislator expressly used the notion of private property, in reality, he sought to express the definition of property in general, given that Art 858 of the Civil Code no longer defines public property by reference to the attributes it confers on the holder, but by reference to the right to property in general and by showing its holders and its object: "Public property is the property right that belongs to the state or to an administrativeterritorial unit over the goods that, by their nature or by the declaration of the law, are of use or of public interest, provided that they are acquired by one of the means provided by law".

Another source of ambiguity of the legal language used in the Civil Code is polysemy, that quality of a word to have several meanings. Although the legal language must be univocal, it is still characterized by the frequency of polysemy. This aspect also has a positive side because the polysemy of words ensures the longevity of legal norms and opens the way for legal interpretation.

If polysemy is accepted as a feature of legislative language, however, synonymy must not be accepted. In this sense, the provisions of Art 37 of Law no. 24/2000 regarding the norms of legislative technique establish the obligation to express the same notion only through the same terms. Unfortunately, the reality of legislative practice is different. An example of 
terminological inconsistency is identified in the Civil Code in the provisions on goods. The code defines by Art 535 goods as things, corporeal or intangible, which constitute the object of a patrimonial right.

The use of the term "good" is debatable because it itself reveals the corporeality, and the notion of incorporeal good clearly contains a contradiction between the two terms (Chelaru, 2014). Moreover, the legislator sometimes uses the notion of "things", other times that of "goods" as an object of patrimonial rights.

For example, it uses with the same meaning in Art 563 Para (4) of the Civil Code, when the term of "good", when the term of "things", to designate the same reality: "The court decision admitting the action in claim filed against the possessor is also opposable to the one holding the good for the owner, being enforceable directly against him. The court decision admitting the action in claim against the holder of the good for the possessor is not opposable to the possessor, if he has not been introduced in the case". The same terminological inconsistency is identified in Art 941 of the Civil Code, in the content of which is used when the phrase of mobile good, which is not defined anywhere in the code, when the phrase of movable property.

To eliminate these ambiguities, we consider that it was preferable to use instead of the word "thing" in the definition of the good, the phrase "economic value" or asset.

Another situation - a source of ambiguity, vagueness and intelligibility of the text of the current code - is found in the fact that the classic notion of "violation" of the law is often replaced by the legislator with a notion such as "infringement" of the law, term which is sometimes synonymous with "violation" of the law in the Code, and sometimes not. For example, in Art 253 C.civ. the expression "non-patrimonial rights that have been harmed or threatened" is used, and not violated or harmed, and in Art 255 Para (6) C.civ. there is talk of "... protection of the violated non-patrimonial right", and not of the right that has been harmed. The explanation found in the literature for such situations was that the texts were written by different authors and were not correlated, which is inadmissible from the perspective of the legislative technique norms (Dănișor, Badea, 2015).

This diversity of wording generates controversy and affects the clarity of language and normative style. At the same time, this diversity "introduces in the legal terminology distinctions, either artificial or inaccurate, affecting the precision of some of the normative statements" (Neculaescu, 2010).

Considering that the term "infringement" of the right is a polysemantic one, it was preferable to avoid its use by the legislator or, if it was chosen, it was necessary to define it in advance, as expressly stated in Art 37 of Law 24/2000 on the norms of legislative technique.

I have illustrated above only a few examples of legal norms from the content of the current Civil Code whose intelligibility is questioned, but the examples can continue. It is equally true that, fortunately, this Code nevertheless responds to the need for a modern legislative framework, representing a coherent response to the need to reform the institutions and fundamental mechanisms of Romanian civil law. 


\section{CONCLUSIONS}

Although subordinated to Union and international law, subject to competition from other rules based on other forms of legitimacy, often affected by lack of predictability and intelligibility, the Civil Code remains the irreplaceable expression of the general will, the expression of democracy and the main formal source of Romanian civil law. Taking into account the special social impact it has on the subjects of law by regulating their conduct, the activity of elaborating a code is extremely complex and implies a great political, legal and even moral responsibility on the part of the legislator.

Regardless of the legislative technique, the role of control and evaluation mechanisms in the elaboration of the law, the bodies involved in the elaboration of legal norms must have as a desideratum towards which at least three intertwining aspects tend: the legal security of the person, simplification and efficiency of rules.

As we have shown in the study, at the level of Romanian legislation, the rules meant to ensure the understanding of the text of the law by the litigant are well outlined, only that, unfortunately, they are not observed. The clarity of the law is vital for the successful exercise of the citizen's rights, and in order to achieve this objective, the correct application of the norms of legislative technique has a decisive role, as they support the increase of the accessibility of the normative acts.

Capitalizing on the literature and the practice of drafting the new Civil Code, critically analyzing the language and style in which it was written, we hope that this study contributes to completing scientific research in this field, joining other works aimed at increasing the quality of legislation, it can be useful for all participants in the law-making process.

\section{REFERENCES}

Dănișor, D. D., Badea S. (2015) Polisemie și ambiguitate în limbajul Codului civil. Revista de Științe Juridice, 26 (1), 134-144.

Deleanu, I. (2011) Accesibilitatea şi previzibilitatea legii în jurisprudenţa Curţii Europene a Drepturilor Omului şi a Curţii Constituţionale române. Revista Dreptul, 8, 52-82.

Duminică, R. (2012) Intelligibility of the Laws - a Desideratum Difficult to Achieve by the Romanian Legislator. In the volume International Scientific Conference: Logos, Universality, Mentality, Education, Novelty. Iaşi: Lumen, 169-187.

Malaurie, Ph. (2005) L'intelligibilité des lois. Pouvoirs - Revue francaise d'etudes constitutionnelles et politiques, 114, 131-137.

Mathieu, B. (2010) La loi. Paris: Dalloz, 144 p.

Mrejeru, I. (1979) Tehnica legislativă. Bucharest: Romanian Academy Press, 228 p.

Nadaud, S. (2008) Codifier le droit civil européen. Bruxelles: Larcier, 464 p.

Neculaescu, S. (2010) Noul Cod civil, între tradiție și modernitate în ceea ce privește terminologia juridică normativă. Revista Dreptul, 12, 11-41.

Oppetit, B. (1998) Essai sur la codification. Paris: Presses Universitaires de France, 96 p.

Osiejewicz, J. (2020) Transnational Legal Communication: Towards Comprehensible and Consistent Law.

Found Sci 25, 441-475. https://doi.org/10.1007/s10699-020-09655-3

Pătulea, V. (2010) Tratat de management juridic şi jurisdicţional. Bucharest: I.R.D.0., 984 p. 
Popa, N., (2020) Teoria generală a dreptului. Bucharest: C. H. Beck, 296 p.

Popescu, S. \& Țăndăreanu, V. (2003) Probleme actuale ale tehnicii legislative. Bucharest:

Lumina Lex, $544 \mathrm{p}$.

Predescu, I. (2006) Elogiu Codului Civil. Revista de Științe Juridice, 1, 7-9.

Richevaux, M. (2002) Limbajul legii și legile limbajului. Buletin de informare legislativă, 22-31.

Tabacu, A. \& Duminică, R. (2012) The Fiduciary Contract and the Administration of the Goods of Another Person in the New Civil Code. A Comparative Outlook. Journal of Legal Studies. Supplementary Issue 3 (1-2), 171-189.

Vida, I. (2012) Legistică formală. Introducere în tehnica şi procedura legislativă, $5^{\text {th }}$ Edition. Bucharest: Universul Juridic, $224 \mathrm{p}$.

Zlătescu, V. D. (1995) Introducere în legistica formală. Bucharest: Rompit, 170 p. 


\title{
THE COMMUNICATIVE ASPECTS OF THE SETTLEMENTS OF THE PARENT - CHILD CONTACTS AFTER THE DIVORCE (POLISH CASE-LAW AND THE INDICATION TO ECHR CASE-LAW)
}

\author{
Izabela Gawłowicz, \\ University of Zielona Góra, Assistant Professor, Ph.D. in Laws, \\ Pl. Słowiański 9, 65-069 Zielona Góra, Poland \\ https://orcid.org/0000-0003-3591-3953 \\ i.gawlowicz@wpia.uz.zgora.pl \\ Piotr Sobański, \\ University of Zielona Góra, Assistand Professor, \\ Ph.D. in Laws. LLM, \\ Pl. Słowiański 9, 65-069 Zielona Góra, Poland \\ Attorney at Law of District Bar Association in Zielona Góra \\ https://orcid.org/0000-0001-8303-1125 \\ piotr.sobanski@adwokatura.home.pl
}

\begin{abstract}
The inspiration for the subsequent consideration is a strong conviction, that courts mean much more in the modern society, than just an arbiter in the disputes. They are role models in so many ways: they make legally desired standards of behavior, they give the proper meaning to the legal institutions by communicating their correct functioning, they verify in the practice the complexity and clarity of legal provisions and by its judges they can create the modern authorities to follow. There is a strong link between the role, that the domestic courts play (or should play) in the law-abiding state, and the impact they put into the society and its values, shaping the views for the young generation, through their consistent attitude in jurisprudence.

Authors analyze the chosen judgments of the domestic family courts, looking for the correct legal vision of the parental authority in Polish law in the first place and for the optimal standard of exercising it by parents in practice, i.a. after the divorce. The analysis is supposed to be the part of more general consideration according to the judicial view of the family as the basic unit of society and its functioning after any kind of breakup. Authors further examine, to what extend such model of regulation in the matter fulfils the general requirements of international and European law. Those considerations have two main goals: to investigate the contribution of Polish family courts into making international standard of parental authority, and to indicate what kind of support those courts can offer to the international society in this field.
\end{abstract}

Keywords: parental authority, family law, rights of children 


\section{INTRODUCTION}

To communicate law comprehensively to its recipients and to reinforce the values protected in the society and expressed in the legal standards is one of the most important tasks of the creation of an independent and effective judiciary system. Any statement of the court can be and supposed to be analyzed in this context. As rightfully states J. Osiejewicz: "The process of learning to respond to direct and indirect instructions begins already in early childhood. During the socialization period, various activities related to responding to instructions are developed and strengthened. Behaviors associated with the adoption of instructions change in age and professional context [...]" (J. Osiejewicz, 2020).

In most of the cases the divorce of parents means for the children not only the life changing family breakdown, but also the collapse of the vision of family in general including the vision of their future family. From this perspective the importance of the way, in which the court will decide about the details of exercising the parental authority, in which the court will find the fair balance between that, what the parents should give and that what the children should have to take also when the family is tear apart, having in mind the very best interest of the child, cannot be overestimated.

The considerations of Authors have two main goals: to investigate, how the Polish family courts implement international standard of parental authority by applying the Polish law in the matter and to indicate what kind of support those courts can offer to the international society in this field. Authors analyze the chosen judgments of the domestic family courts, looking for the correct legal vision of the parental authority in Polish law in the first place, for the definition and the component factors of the institution of parental authority and for the optimal standard of exercising it by parents in practice, i.a. after the divorce. The analysis is the part of more general consideration according to the judicial view of the family as the basic unit of society and its functioning after any kind of breakup. Authors further examine, to what extend Polish model of regulation fulfils the general requirements of international and European law in the matter with special regard for the Convention for the Protection of Human Rights and Fundamental Freedoms 1950 (Rome 4 Nov. 1950).

\section{MATERIALS AND METHODS}

According to Article 48 Section 1 of the Constitution of the Republic of Poland, parents shall have the right to bring up their children in accordance with their own convictions. Pursuant to Article 48 Section 2 of the Constitution, limitation or deprivation of parental rights may be effected only in the instances specified by statute and only on the basis of a final court judgment. Detailed regulations are stipulated in the statute of 25 February 1964 Polish Family and Guardianship Code; FGC (Kodeks Rodzinny i Opiekuńczy; KRO).

The main principle is that a minor child remains under parental authority until the age of majority (Article 92 FGC), which is held, as a rule, by both parents. Pursuant to the Article $93 \S 1$ FGC, both parents have parental authority. This means that each of the parents is the subject of parental authority. In accordance with the content of Article $94 \S 1$ FGC, if one of the parents is dead or does not have full legal capacity, parental authority is vested in 
the other parent. The same applies when one of the parents is deprived of parental authority or when his parental authority is suspended. According to Article $94 \S 3$ FGC, if neither of the parents has parental authority or if the parents are unknown, custody is established for the child.

FGC does not contain a definition of parental authority. An indication for the interpretation of this provision may be precisely Article 95 § 1 FGC (Wierciński, 2014). It follows from the wording of Article $95 \S 1$ FGC that parental authority includes, in particular, the obligation and right of the parents to exercise custody of the person and property of the child and to raise the child, with respect for its dignity and rights. It should be emphasized that the legislator used the phrase "in particular" (Jędrejek, 2019). Article $95 \S 1$ FGC does not contain enumerative list of all components of parental authority. According to Article $96 \S 1$ FGC, the parents raise the child under their parental authority and lead the child. They are obliged to take care of the physical and spiritual development of the child and to prepare it adequately to work for the good of society according to its talents (Jędrejek, 2019; Stępień, 2019).

The analysis of above regulations leads to the conclusion that the general scope of parental authority is determined by the regulations of Article 95 FGC and Article 96 FGC (Jędrejek, 2019). Custody of the child includes in particular: raising the child, leading the child, providing the child appropriate living conditions and the obligation to care for the health and safety of the child. The raising of the child consists of: care for its proper mental and physical development; attention to developing abilities and talents; providing the child with an appropriate level of knowledge according to his abilities and predispositions. Moreover, the raising of the child includes caring for its fulfillment of compulsory education and taking into account the need to provide appropriate assistance in order to obtain satisfactory learning results by the child. Parents therefore decide on all educational matters related to the child, including, for example, secular and religious upbringing, including the choice of religion, shaping the rules of ethics and character of the child, diligence, conscientiousness, etc. It should be noted however, that according to the European Court of Human Rights' case - law, despite the strong conviction, that both parents should be able to direct their child's religious upbringing, the national courts should interpret the child's best interest in a way to restrict the exposure of the child to parental religious beliefs or practices in some circumstances like guarantying the child's future choice of religion, saving the physical integrity of the child, securing the child's contact and relationship with both parents, respecting the child's educational choices, and the child's relationship with both parents' religious community. The domestic courts should have a wide understanding of what benefits the child and should consider the cautious limitation in the parental teaching of their minority beliefs (see more: Dogru v. France, No. 27058/05, 4 December 2008, ECtHR; Kervanci v. France, No. 31645/04, 4 December 2008, Grzelak v. Poland, No 7710/02, 15 June 2010). As also indicated above, the preparation of a child for social life is equally important. Proper preparation of the child for future work may also include higher education, if its talents, ambitions and perseverance are sufficient to not only begin, but also continue and successfully complete the studies (Jędrejek, 2019; Trybulska-Skoczelas, 2014; Seremak, 2021; Kucwaj, 2010). 
It should be emphasized that the analysis of the proper performance of obligations under Article 96 FGC cannot be done automatically. The manner of their implementation, including the obligation to prepare for the profession, depends on the specific situation concerning the child. The duty to provide the child with necessary medical care is encompassed in the obligation of care for the physical development of the child (Article 96 § 1 FGC) (Jędrejek, 2019; Ciepła, 2011; Stępień, 2019).

The sphere of child management includes factual and legal actions such as: determination of the place of stay, temporarily entrusting the child to another person, choosing schools, choosing extracurricular activities, control of spending free time, control of access to information, etc. It is also necessary to protect the child from bad environmental influences, drug addiction, pedophilia, etc (Jędrejek, 2019; Trybulska-Skoczelas, 2014).

The most important rule is the clause which refers to the best interests of the child (Article $95 \S 3$ FGC). It is fundamental legal principle in family law when making decisions regarding the child. According to Article $95 \S 3$ FGC, parental authority should be exercised as required by the best interests of the child and the social interest.

Custody of the child's property is regulated primarily in Article 101 FGC. Pursuant to Article $101 \S 1$ FGC, the parents are obliged to exercise due diligence in managing the property of the child under their parental authority. Custody of the child's property includes: management of the property of the child, disposing of income from this property, settlement with property management, control of the financial situation of the child, taking actions to prevent any irregularities in the management board performed by other persons. It is worth noting that the management of the property of the child consists of factual and legal administration, and the right to represent the child is inextricably linked with it. Pursuant to Article $101 \S 3$ FGC, parents may not, without the consent of the guardianship court, perform actions exceeding the scope of ordinary management or consent to such actions by the child. The purpose of Article $101 \S 3$ FGC is to limit ability of the parents to act to the detriment of the child (Jędrejek, 2019; Sokołowski, 2013; Trybulska-Skoczelas, 2014; Romanow, 2021).

Art. 96 FGC expresses the principle of personal exercise of parental authority by the parents. Their duty to take care of the child and his property should be performed by them personally. The authority is exercised by parents on an exclusive basis, which means that no one can take care of them in this regard. It should be emphasized that parental authority is an inalienable and non-hereditary right. It may happen that due to various circumstances the exercise of parental authority will be entrusted to one of them without depriving the other parent of parental rights (Jędrejek, 2019; Supreme Court judgement 4 August 1999, II CKN 601/98).

The implementation of the above obligations of parents should be provided equally. This means that parents cannot consider certain responsibilities more important than others that will be neglected. There is no hierarchy of rights and obligations that are components of parental authority. The breach of any obligation constitutes a breach of parental authority. Therefore, it should be emphasized that the interference of the court with parental authority takes place when this authority is not properly exercised. What is more, the interference of the court with parental authority has to take place in divorce cases and in separation cases (Jędrejek, 2019; Trybulska-Skoczelas, 2014). 
According to Article $58 \S 1$ FGC, in a divorce judgment, the court decides on parental authority over a joint minor child of both spouses and on contacts between parents and the child. The court takes into account the agreement written by the spouses on the manner of exercising parental responsibility and maintaining contact with the child after divorce, if it is in the best interests of the child. Article $58 \S 1$ a FGC states as follows: "In the absence of an agreement referred to in $\S 1$, the court, taking into account the right of the child to be brought up by both parents, decides how to exercise parental authority jointly and maintain contact with the child after divorce. The court may entrust the exercise of parental authority to one of the parents, limiting the parental authority of the other to specific duties and rights in relation to the child, if it is in the best interest of the child".

Pursuant to Article 61 (3) § 1 FGC, the provisions of Article 57 FGC and Article 58 FGC apply to separation. Legal separation is an alternative for spouses who, for various reasons, do not want a divorce. The effects of separation, apart from the termination of marriage, are similar to those of divorce. According to Article 61 (6) $§ 1$ FGC, at the joint request of the spouses, the court will abolish the separation. The unanimous request of the spouses is binding on the court, and the rationality of their decisions is not subject to control. The court only examines whether the will to end the separation was consciously and freely expressed (Sylwestrzak, 2020). Pursuant to Article 61 (6) § 3 FGC, when abolishing the separation, the court shall decide on parental authority over the joint minor child of the spouses.

The decision on parental authority lies with the divorce court and the guardianship court. There is no doubt that in the course of a divorce or separation case, the court hearing these cases takes over the functions of the guardianship court in terms of parental authority (Supreme Court resolution 11 April 2019, III CZP 105/18).

As long as the legislator regulated in Article $95 \S 1$ FGC the content of parental authority, Article $97 \S 1$ FGC refers to its performance (Jędrejek, 2019). According to Article 97 $\S 1$ FGC, if both parents have parental authority, each of them is obliged and entitled to exercise it. The legislator granted parents with parental authority the right and obligation to exercise it independently. The wording of this provision shows that each of the parents may independently take actions relating to the person and property of the child, including actions on its behalf with other persons (Trybulska-Skoczelas, 2014).

According to Article $97 \S 2$ FGC, the parents decide together on the essential matters of the child. These matters are exceptions to the principle included in Article $97 \S 1$ FGC. The scope of important matters of the child can be divided into two groups of cases: those which are determined by their general nature and matters important due to their importance only in a given specific case (Sokołowski, 2013). Important matters of a child should be understood as both factual and legal actions. In these matters, parents should first of all work out an agreement. In the doctrine and jurisprudence it is assumed that these are matters related to, among others, change surname or first name of the child, choice of kindergarten, choice of school, choice of medical treatment (Trybulska-Skoczelas, 2014). For the matters referred to in Article $97 \S 2$ of FGC the jurisprudence also includes a change of citizenship by a child (Supreme Court judgement 6 November 1956, II CR 898/56). The decision on the place of stay of the child is a decision on an important family matter, too (Supreme Court resolution 23 Mai 2012, III CZP 21/12). Also, a departure of the child abroad to spend holidays 
there requires the consent of both parents exercising parental authority (Supreme Court judgement 6 March 1985, III CRN 19/85). The case referred to in Article $97 \S 2$ FGC is, inter alia, the case for issuing a passport to the child. The decision on the participation in extracurricular activities of the child is a decision on an important family matter (TrybulskaSkoczelas, 2014).

Pursuant to Article $97 \S 2$ FGC, the parents decide together on the essential matters of the child, however, in the absence of an agreement between them the guardianship court decides. The issue is resolved by the guardianship court at the request of one of the parents. The ruling of the guardianship court on important matters of the child may take place only after the parents are allowed to submit statements, unless hearing them would be associated with excessive difficulties. The guardianship court should take steps to resolve the dispute amicably. When deciding on parental authority, the court should be guided primarily by the best interests of the child and the public interest, and not by the interests of one or both parents (Trybulska-Skoczelas, 2014; Ciepła, 2011; Jędrejek, 2019).

A breach by a parent of the obligation to jointly make decisions on the essential matters of the child may lead to judicial interference with parental authority under Article 109 FGC assuming that such behavior of the parent constitutes a threat to the welfare of the child. It may lead to depriving parental authority pursuant to Article $111 \S 1$ FGC when accepting such behavior as an abuse of parental authority (Trybulska-Skoczelas, 2014).

In Article $111 \S 1$ FGC the legislator indicated three premises justifying depriving parents or one of the parents of parental authority. The first premise is a permanent obstacle to the exercise of parental authority. The occurrence of a permanent obstacle constitutes the basis for the deprivation of parental authority. In the event of a temporary obstacle, there is a reason not for deprivation but for suspension of the exercise of parental authority (Article 110 FGC). The second premise depriving of parental authority is the abuse of parental authority, and the third one is gross neglect of obligations towards the child (Jędrejek, 2019). The assessment of behavior of the parents should also take into account the possibility of a negative impact on the upbringing process. In such a situation it is justified to deprive the parent of parental authority. Alcohol abuse, engaging in a criminal practice and evading the alimony obligations are sufficient reasons for depriving a child of parental authority pursuant to Article 111 § 1 FGC (Supreme Court judgement 10 Mai 2000, III CKN 775/00). It is worth noting that the deprivation of parental authority, although it is the most severe measure, does not have to be preceded by other "restrictive" ordinances (Supreme Court judgement 3 December 1998, II CKN 871/98).

Pursuant to Article $111 \S 2$ FGC, in the event of cessation of the cause, which was the basis for deprivation of parental authority the guardianship court may restore parental authority. The guardianship court may, pursuant to Article 109 FGC, make any order which, in the given circumstances, is required by the best interests of the child, and thus - which is required for the proper spiritual, mental and physical development of the child. There is no doubt either in the jurisprudence or in the doctrine of the admissibility of issuing the following orders: ordering the parents to place the child in a hospital or sanatorium, prohibiting the discharge of the child from the hospital, expressing consent to perform the necessary surgery. In the case of the child who habitually consumes alcohol or other drugs leading to intoxication, the 
court may order that the child to be placed in a psychiatric hospital or other appropriate treatment facility (Jędrejek, 2019).

Orders issued by the court in accordance with Article 109 FGC do not constitute reprisals against parents. Their sole purpose is to protect endangered welfare of the child. The issuing of orders is necessary in the event of improper exercise of parental authority. Such a measure is a warning to parents that they are not exercising their power correctly, which may lead to further restriction and, subsequently, to the deprivation of parental authority (Jędrejek, 2019; Supreme Court judgement 27 October 1997, III CKN 321/97).

In all matters relating to the person or property of the child, including matters relating to parental authority, the court is obliged to hear the child if its mental development, health and degree of maturity allow it. Moreover, the court is obliged to take into account, as far as possible, the reasonable wishes of the child (Article $576 \S 2$ Civil Procedure Code; CPC) (Jędrejek, 2019).

It follows from the wording of Article $97 \S 2$ FGC that "irrelevant" matters are handled by each of the parents. Naturally, parents should inform each other about them. However, in less important, especially current matters, each of the parents can and should act individually, although this cannot contradict the general arrangements already made. If one of the parents does not respect the rights of the other parent it is possible to enforce them to comply with these rights. However, due to the educational nature of parental authority, the basic sanction for failure to respect the rights of the other parent is restriction, and in gross cases even deprivation of parental authority (Jędrejek, 2019; Trybulska-Skoczelas, 2014).

In urgent matters, such as the health of a child, it should be assumed that each parent can exercise authority (Jędrejek, 2019).

The supplement to Article $95 \S 1$ FGC is Article 98 FGC which gives parents the right to represent their child. According to Article $98 \S 1 \mathrm{FGC}$, the parents are the legal representatives of the child remaining under their parental authority. If the child remains under parental authority of both parents, each of them may act alone as the legal representative of the child. The statutory representation of parents referred to in Article $98 \S 1$ FGC covers the performance of substantive legal actions, actions before administrative organs and actions before courts (Trybulska-Skoczelas, 2014).

Pursuant to Article 66 CPC, a natural person without procedural capacity may take procedural steps only through a statutory representative. As indicated above, according to Article 98 $\S 1$ FGC the parents are the legal representatives of the child under parental authority. Parents may therefore file claims in a trial on behalf of a child or motions in non-trial proceedings, and more broadly - take all procedural steps. Article $98 \S 1$ FGC introduces the principle of independent representation of the child by each of the parents. The provision of Article 97 FGC should not be understood that in essential matters relating to the child, the principle of independent representation of the child by each of the parents is excluded. One-person representation is also sufficient in important matters. The phrase "parents decide together" used in Article 97 § 2 FGC indicates that it is not about joint representation but about resolving a dispute regarding an important action concerning a child. However, the principle of oneperson representation does not apply in the case of important matters of the child, if one of the parents has raised an objection (Jędrejek, 2019; Trybulska-Skoczelas, 2014). 
In Article $98 \S 2$ FGC the legislator has included prohibitions regarding the representation of a child by parents. Pursuant to Article 98 FGC, the parents can always represent the child in court, unless it is a matter of legal transactions between children under their parental authority or between the child and one of the parents or their spouse. Also in matters other than those mentioned in Article $98 \S 2$ FGC, both procedural and non-trial, neither parent may represent a child if in a case in which parents and children act as parties or participants in the proceedings, a conflict of interests may arise between them. Then the interest of the child excludes representing by any of the parents (Jędrejek, 2019; Trybulska-Skoczelas, 2014; Stępień, 2019).

It follows from Article $98 \S 2$ FGC and Article $98 \S 3$ FGC that the exclusion of parental representation in proceedings should be assessed ad casum and accepted only when there is, even if only theoretically, the possibility of a conflict of interest. In any case in which parents and children are parties or participants, the court is obliged to investigate whether there is a hypothetical possibility of a conflict of interest between them. In such a situation neither parent can represent the child in court. The court hearing the given case may not reject the application, but is obliged to apply to the guardianship court for the appointment of a curator for the child (Article 99 FGC) (Jędrejek, 2019; Trybulska-Skoczelas, 2014).

It supposed to be noted also, that the European Convention on Human Rights (ECHR) contains just a few references expressis verbis to children, i.a. the right to respect for private and family life protected in Article 8 of the ECHR - have special meaning to children. According to the ECtHR jurisprudence the respect for family life is the existence in domestic law of legal safeguards that render possible as from the moment of birth the child's integration in his family. The recognition by ECtHR respect for family life under Article 8 of ECHR requires legal recognition of social and biological ties between parents and children. This has been made possible by applying the right of individual petition by children and parents as their representatives and has led to an increasing number of applications before the European Court of Human Rights.

The task of the curator is to perform procedural actions on behalf of and with effect for the child. Pursuant to Article $98 \S 2$ FGC, the curator representing the child is authorized to perform all actions related to the case, also in terms of appealing against a judgment and executing the judgment. In any event, the curator should be guided by the best interests of the child. The task of the curator is also to assist the court in collecting and assessing evidence from the point of view of the good of the child. Improper defense of the interests of the child by the curator does not justify the reopening of the proceedings, but may lead to liability for damages. If, in proceedings involving parents and a child, the child will not be represented by the curator, but by one of the parents, the proceedings will be null and void because the child is deprived of the ability to defend their rights (Article 379 Point 5 CPC) (Jędrejek, 2019). As indicated above, the clause which refers to the best interests of the child is fundamental legal principle in family law.

The analysis of Article $98 \S 3$ FGC in connection with Article $98 \S 2$ FGC leads to the conclusion that one of the parents may represent the child in the process of maintenance claimed from the other parent. The complainant is the child and the parent is the child's legal representative (Trybulska-Skoczelas, 2014). 


\section{CONCLUSIONS}

The shape of parental authority regulation in Polish law seems to be optimal for the ensuring the child's best interests understood as a situation in which the child is brought up in a family in an atmosphere of love, peace, understanding and respecting its identity and in conditions that ensure its needs and personal development. The Polish courts express quite clearly, what is the content of the parental authority institution notwithstanding any shortcomings in the legal regulations. The relations between the provisions of Polish acts of law in the matter and the ECHR provisions are in fact incidental, because ECHR quite rarely refers to the children directly. However it should be noted, that in front of the ECtHR had place a few interesting cases, like Zawadka v. Poland, where both parents have been so deep in the mutual conflict, that they have been constantly refusing of any kind of cooperation between themselves despite the sake of their child. There is no doubt, that in the ECtHR's view the universal rule of the child's protection is to be guided by the best interest of the child in any circumstances - also in the conditions of family's conflicts. Because of that the lack of the strict obligation of the child's and its rights protection under the provisions of ECHR does not seem to be of such importance in practice.

\section{REFERENCES}

\section{Polish Case-law}

Supreme Court judgement 6 November 1956, II CR 898/56.

Supreme Court judgement 6 March 1985, III CRN 19/85.

Supreme Court judgement 27 October 1997, III CKN 321/97.

Supreme Court judgement 3 December 1998, II CKN 871/98.

Supreme Court judgement 4 August 1999, II CKN 601/98.

Supreme Court judgement 10 May 2000, III CKN 775/00.

Supreme Court resolution 23 May 2012, III CZP 21/12.

Supreme Court resolution 11 April 2019, III CZP 105/18.

\section{ECHR case-law}

Zawadka v. Poland, Case of Zawadka, No. 48442/99, 23 June 2005

Dogru v. France, No. 27058/05, 4 December 2008, ECtHR;

Kervanci v. France, No. 31645/04, 4 December 2008, ECtHR

Grzelak v. Poland, No 7710/02, 15 June 2010, ECtHR

\section{Books}

Ciepła H. (2011). Kodeks rodzinny i opiekuńczy. Komentarz aktualizowany, LEX Sokołowski T. (2013). Kodeks rodzinny i opiekuńczy. Komentarz aktualizowany, LEX Jędrejek G. (2019). Kodeks rodzinny i opiekuńczy. Komentarz aktualizowany, LEX Sylwestrzak A. (2020). Kodeks rodzinny i opiekuńczy. Komentarz aktualizowany, LEX Trybulska-Skoczelas E. (2014). Kodeks rodzinny i opiekuńczy. Komentarz aktualizowany, LEX Wierciński J. (2014). Kodeks rodzinny i opiekuńczy. Komentarz aktualizowany, LEX Sylwestrzak A. (2020). Kodeks rodzinny i opiekuńczy. Komentarz aktualizowany, LEX Trybulska-Skoczelas E. (2014). Kodeks rodzinny i opiekuńczy. Komentarz aktualizowany, LEX Wierciński J. (2014). Kodeks rodzinny i opiekuńczy. Komentarz aktualizowany, LEX 


\section{Book chapters}

Stępień M. (2019). Atrybuty władzy rodzicielskiej. In J. Helios, W. Jedlecka, A. Kwieciński (Eds.), Prawo wobec wyzwań współczesności Wybrane problemy teoretycznoprawne i dogmatycznoprawne (pp. 225-237). E-Wydawnictwo. Prawnicza i Ekonomiczna Biblioteka Cyfrowa. Wydział Prawa, Administracji i Ekonomii Uniwersytetu Wrocławskiego

\section{Journal articles}

Kucwaj M. (2010). Wybrane przepisy kodeksu rodzinnego i opiekuńczego jako źródła obowiązku gwaranta, Studia Prawno-Ekonomiczne, LXXXII, 125-148

Osiejewicz J. (2020) Transnational Legal Communication: Towards Comprehensible and Consistent Law, Foundation of Science, 2020(25), 441-442, https://doi.org/10.1007/s10699-020-09655-3

Romanow S. (2021). Zarząd majątkiem dziecka sprawowany przez rodziców. Transformacje Prawa Prywatnego, 1, 125-152

Seremak K. (2021). Ograniczenie władzy rodzicielskiej przez umieszczenie dziecka w placówce opiekuńczo-wychowawczej w świetle badań aktowych. Krytyka Prawa, 1, 139-158 


\title{
LEGAL GUARANTEES ON PUBLIC CONTROL
}

\author{
Zhanna A. Kovalenko, \\ Kyiv National University of Trade and Economics, \\ Postgraduate student of the Department of Administrative, \\ Financial and Information Law, \\ 19 Kyoto Str., Kyiv, Ukraine, 02156 \\ https://orcid.org/0000-0002-5028-2400 \\ zhanna.kovalenko2018@knute.edu.ua
}

\begin{abstract}
Public control is an important mechanism for influencing upon public authorities. Its effectiveness ensures social participation within public administration indeed. The effectiveness of public control depends on the quality of its legal regulation and, in particular, upon perfection of mechanisms for public control.

Numerous shortcomings of the existing mechanisms for exercising public control are primarily considered due to the legal uncertainty of the guarantees on public control. After all, the guarantees on public control ensure proper functioning of the institution of public control and the effective implementation of the legal status of individuals in the field of public control and the entire social sphere in general. Without their comprehensive analysis, including clarification of its legal nature and essence, it is impossible to build, describe in detail and consolidate legislatively the system of guarantees on public control.

Within the frame of the study it has been found that the legal nature of the guarantees on public control and the specifications of their essence largely depend upon the kind of content that is embedded into the concept of the law. The author also believes that the most accurate way to reveal the nature of legal guarantees seems possible with the help of instrumental theory of law, namely being the key concept of "legal means". In this article the emphasis is stressed onto one of the main reasons for the existence of controversial points and differences in the understanding of legal guarantees, including public control, where there is the ambiguity for the basic category, i. e. "guarantee".

The article also formulates definitions of legal guarantees in the most general sense, as well as from the standpoint of instrumental theory of law. As a result, the author's understanding of legal guarantees on public control has been introduced.
\end{abstract}

Keywords: civil society, public authority, public administration, public control, legal guarantees.

\section{INTRODUCTION}

Social changes in Ukraine, in particular related to European integration processes, the development of civil society and the strengthening of democratic institutions have led to the transformation of relations between the state and the individual.

In order to implement the constitutional principle of guaranteeing human and civil rights and freedoms, public authorities have begun active involvement of the public not only into 
the decision-making process, but also in for creation of mechanisms that ensure direct participation of citizens within public administration (Shaulska, 2019). Just during the last few years, new forms of such a participation have been introduced in our country as follows: public councils, e-petitions, participation budget, public consultations, etc.

Being an integral part of the constitutional and legal status of human and citizen, public participation in public administration is one of the defining features of the civil society and legal democratic state. Ensuring for Ukraine of this participation is a means of achieving internal stability and one of the main conditions for full integration into European community.

Along with this, it should be noted that the main condition for the real participation of citizens in public administration is effective public control (Orel \& Smagliuk, 2018). Indeed, by promoting human and civil rights and freedoms and the interests of society in the whole, it's being an important mechanism for influencing authorities on all levels through the process of developing, adopting and implementing government decisions, as well as workout and embodiment of public policy (Gurzhii T., 2018).

Despite the importance of public control within the democratization of public institutions, the legal regulation of the relevant sphere of public relations is not of high quality. This is primarily due to the imperfection of existing mechanisms for public control. Insufficient regulation of the majority of legal procedures on the organization and implementation of public control creates just barriers to effective communication between civil society and the state (Ishchuk, 2018).

Numerous shortcomings of the public control mechanisms are primarily stipulated by the legislative unregulated guarantees on public control. After all, being general and important condition for the implementation of legal status of a person in relations with public authorities, the guarantees of public control create necessary and most favorable conditions for ensuring implementation, protection and defense of this right, as well as they increase the effectiveness of public control as mechanism for influencing public authorities.

Legal uncertainty of the guarantees on public control creates, first of all, problems in law enforcement: these are gross errors in the application of some rules of law, and the impossibility of implementing other ones. In addition, this unresolved issue makes it impossible to improve qualitatively legal regulation of the relevant sphere of relationships, including mechanisms for public control.

The situation is being further complicated by the fact that domestic scientists have not yet developed unanimous conceptual approach to defining the guarantees of public control phenomenon. Therefore, this in its turn complicates the process of building a system of the guarantees and their legislative consolidation.

At the same time, it should be noted that the legislative consolidation of guarantees of public control is to have positive impact upon the effectiveness of public participation in public administration, as well as on the stage of human rights and freedoms ensuring.

\section{LITERATURE REVIEW}

Many prominent lawyers have studied important aspects of public control, including its guarantees. In particular, I. O. Skvirsky investigated ideological basis for the institute of public control (Skvirsky, 2013). Guarantees of public control over the public administration's 
observance of human and civil rights and freedoms as one of the types of ensuring legality and discipline in public administration have become the subject of S. G. Stetsenko's consideration on this issue (Stetsenko, 2007). Legal guarantees of public control have found detailed enlightenment in 0. D. Tereshchuk's monograph "Administrative and legal principles of public control over law enforcement activities in Ukraine: theory and practice" (Tereshchuk, 2018). S. M. Khomov has been researching and considering juristic guarantees of public control over the activities of the SFS of Ukraine for a long period of time (Khomov, 2016). Instead, the issue of legal guarantees of public control, despite all its importance, remains out of the attention of domestic lawyers for many years in a row. The vast majority of these sphere researchers cover in their works just certain aspects of the problem, without resorting to comprehensive consideration of this unique phenomenon.

\section{RESULTS AND DISCUSSION}

The Constitution of Ukraine identifies the rights and freedoms of human and citizen, and their guarantees as a priority for the Ukrainian state. According to Part 2 of the Article 3 of the Basic Law, they determine the content and orientation of the state. The state is accountable before the personality for its activities, i. e. the establishment and the protection of human rights and freedoms is being fundamental duty of the state (Constitution of Ukraine, 1996).

One of these constitutionally proclaimed human rights is the right to participate in state affairs administration (Article 38 of the Constitution). In particular, the right of participation provides the opportunity to express and defend their views publicly, to promote effective solutions on solving problems of the society solely or in community with other citizens, to ensure consideration of common interests in the development, adoption and implementation of government decisions, to work out and implement state policy, to carry out control at all stages of cooperation with public authorities, to adjust the activities of the latter in accordance with the agreed positions (Dakhova, 2014).

The overall realization of the right to participate in management of public affairs depends on whether the community has effective mechanisms for influencing public authority (Karmaza, 2018).

Today, the community has a significant number of instruments to interact with public authorities and local governments: these are citizens' appeals, including electronic petitions, public consultations, public hearings, and participation in the work of advisory bodies to the executive authorities, etc.

Among these mechanisms, public control occupies important place. Being a derivative of the right to participate in administration of public affairs, the right of carrying out public control allows to identify violations of law, rights, freedoms and legitimate interests of individuals and legal entities; the interests of society, assess the consequences of those actions, and also to prosecute guilty persons to responsibility at all stages of the process of development; adoption and implementation of government managerial decisions, development and implementation of state policy. Therefore, just by carrying out of the control civil society acts as an equal partner of the state, and has the opportunity to "adjust" its activities in accordance with public interests. 
Legal regulation of relations in the field of organization and implementation of public control, which is the regulation of participants' behavior in public relations through legal means (Petryshyn, 2014, p. 134), finds its direct manifestation in the forms (sources) of law, being indispensable key to the stability of these relations and to the harmony of their development. The effectiveness of public control depends on the quality of legal regulation.

Despite all the value of public control, the right to carry it out is not constitutionally defined. In addition, there is no special legal act that regulates relations in the relevant sphere of activity. Instead, the great number of sectoral normative regulations declares the relevant law. Moreover, those few of them, which establish the mechanisms and forms of this right realization, often come into conflict with each other or some legislative acts, but regulate the relevant relations quite fragmentarily.

The unresolved number of issues in the field of organization and implementation of public control often leads to the fact that participation in public administration is just formal. Failure to take into account the interests of the society is the norm rather than the exception to the general rule. After all, insufficient regulation of the procedure for bringing public authorities and officials to justice allows the relevant actors to "ignore" public opinion (Gurzhii, 2020). One of those clear examples is the situation when public hearings are held, proposals based on their results are submitted, but local authorities not just delay the consideration of these proposals, but also do not consider them at all.

The same situation is concerning the settlement of the issue on public control guarantees. At the same time, it is quite obvious, that the formation of a proper legal basis and improvement of the existing one is impossible without guarantees of public control, their clearly constructed, detailed and legally established system. After all, the guarantees themselves are to ensure proper functioning of the relevant institution and effective implementation of the legal status of individuals in the field of public control and the public sphere in general (Mrówczyński, 2020).

Unfortunately, despite all the obviousness of this conclusion, nowadays the domestic legislator still cannot "boast" its conceptually holistic approach to understanding the guarantees on public control, including legal ones.

In our opinion, the development of conceptually holistic approach to understanding the legal guarantees on public control is possible only on the basis of comprehensive analysis of their nature and essence. Regarding this, comprehensive approach requires considering relevant guarantees from the standpoint of the basic concepts on legal understanding, which differently reveal the essence and social goals of law. After all, legal guarantees, as well as subjective law, legal obligation and legal responsibility are separate legal category, and therefore the legal nature of these guarantees, the specification of their essence largely depends on what meaning has been embedded into the concept of the law.

Almost the only scholar who has studied legal guarantees in terms of modern approaches to legal understanding is Professor E. V. Biloziorov. In particular, this scientist revealed the content, which is contributed into legal guarantees by the supporters of natural law concepts, positivism and sociological approach. He also made an attempt to determine the essence of the relevant guarantees in several aspects, namely in functional, instrumental, axiological, 
ideological, information-communicative, structural-substantive, social and cultural, and of course evolutionary one in the whole.

In particular, as E. V. Biloziorov noted, representatives of the naturally legal approach interpret legal guarantees through legal ideas, i. e. principles. For the positivists legal guarantees are means for establishing law and order in society. From the standpoint of the sociological approach, legal guarantees are socially conditioned phenomenon, i. e. factual relations reflected in the minds of people, within their interests, motives and goals, due to legal regulation subsequently reproduced through government authorities and public formations, and then within the activities of law-making bodies (Biloziorov, 2017, p. 23).

At the same time, within the frame of social and cultural aspect, legal guarantees, according to scholar's opinion, should be considered as social and cultural phenomenon, the main manifestations of which are legal culture and legal consciousness. In the functionalinstrumental aspect, the mutual influence of legal guarantees and other social spheres of life (politics, economics, religion) has been already determined; in the axiological aspect, legal guarantees is the category of great value; in the ideological one it's as an expression of a certain ideology (legal guarantees as a measure of freedom or some certain possibilities); in information and communication aspect, legal guarantees are an opportunity to receive and transmit information; in structural and substantive aspect, the features of legal guarantees, their content and nature has been revealed; in evolutional - it is origin, development and formation of legal guarantees.

As a result, E. V. Biloziorov emphasizes upon complexity and versatility of the concept of "legal guarantees". In his opinion, these guarantees are both a phenomenon of social reality and a legal phenomenon. At the same time, the scholar notes that the concept of legal guarantees is formulated within the social environment, where the features of the legal system, as well as the legal doctrine of the state is very important aspect in understanding for their essence (Biloziorov, 2017, p. 23).

Indeed, law is unique and multidimensional phenomenon, complex and polyhedral, social and polysemantic one, which determines the multifaceted nature of the phenomena determined by it, including legal guarantees of public control.

At the same time, along with the statement on importance of all existing concepts of legal understanding, it should be noted that the position of the legislator is to serve as "point of support" for the practical comprehension of legal guarantees on public control nature.

The legislator proceeds out from three aspects of understanding the law: general social (natural law), objective (positive law) and subjective.

Thus, general social law is an ascending element of such a social phenomenon like the law. It is the "foundation" for the development of objective law, as well as for subjective law either.

General social law arises long ago before the emergence of the state, and it exists independently of its own will. It has "accompanied" humanity since its inception, being reflection of human nature and inextricably linked to it. At the heart of this right, there are moral values and, above all, freedom and justice as the most essential goods in the conditions of public life. The initial form of existence of this right is the social consciousness. 
Manifestation of general social law are functionally different rights-opportunities (the right to life, the right to self-determination, the right to free use of natural objects, the right to property, the right to humane treatment of others, the right to freedom of creativity, the right to self-government, etc.), which ensures the very existence of a human. The content of these rights-opportunities is dynamic, and it depends on the level of social development. Natural law is not to be distributed (applied) onto relations of artificial origin, namely: relations arising in the field of human communities, which are connected to the state or exist in the form of state bodies (Nikolayeva \& Gurzhiy, 2021, pp. 42-49).

As T. 0. Gurzhiy righteously notes, "law in general social sense is the social awareness of the generally recognized, inherent inside human nature possibilities of a person abstractly taken through relations with other arbitrarily taken people; a set of natural human rights, which serve as a standard for the subsequent creation of legal norms, i. e. the regulations of subjective law “(Nikolayeva \& Gurzhiy, 2021, p. 46).

Objective law is epy part of objectively existing social environment. It exists independently of the will (desire) of an individual. Positive law acts as a product of the state (though not that way only) and functions within the country, or in the world, etc. Morality is not the predominant factor in the content of objective law. The initial form of positive law is a legal norm. Forms of expression for this right are normative legal acts, legal doctrine, legal custom, legal precedent, etc.

Traditionally, the objective law is considered as kind of social norms, in particular, as set of specific social norms (legal (juridical, or norms of law)). At the same time, norms of law are regulations established, recognized or sanctioned by the competent state body or by another general order; they are binding rules of conduct that regulate public relations in the interests of a human, citizen and society, and provide for the possibility of state coercive measures (including liability to the state) in case of their violation (Nikolayeva \& Gurzhiy, 2021, pp. 52-59). In general, objective law is the system of norms (rules of conduct or behavior) governing the possibility and the order of provision on human (person) needs, as well as satisfaction of his/her interests.

In its turn, subjective law is closely related to objective law: subjective law as it is being a dynamic manifestation of objective law. As a social value, subjective law is an opportunity, which is legally consolidated and guaranteed by society to satisfy a person, a citizen and other subjects of the law according to their needs and interests. As a juridical possibility, this law is the system of powers, which exists in the unity and for implementation of them. Among these powers are the following: the right to perform their own actions (active doings), which is the primary element of subjective law; the right to demand others' actions as the performance or observance of juridical obligation, i. e. the preconditions for legal opportunity realization; the right for protection by the state, i. e. the right that arises in case of violation of legal obligation, which is the obstacle on the implementation of subjective law (Nikolayeva \& Gurzhiy, 2021, pp. 60-62). For example, the right to education implies the obligation of the state to ensure the availability and free of charge education. Violation of this right is the cause for bringing the perpetrators to judicial liability.

Therefore, within the frames of general social understanding of the law, legal guarantees should be considered as phenomena of objective reality, due to the very nature of a human, 
the existence of which ensures implementation, protection and defense of human rights as the basis for freedom and justice. In the context of objective understanding of the law, legal guarantees or juridical guarantees should be considered as rules of law that meet the needs and interests of a person. At the same time, in the context of subjective understanding, they are taken up as separate elements (means) of the mechanism for legal regulation, which ensure implementation, protection and defense of legally consolidated capabilities of legal entities to meet their needs and interests.

It goes without saying, that in order to reflect all these aspects as for the definition of legal guarantees on public control is impractical, since it is to make it too "cumbersome" and unsuitable for scientific and practical use. Therefore, when making definition we try and limit ourselves to stating the legal nature of the guarantees on public control.

However, in our study we proceed from the fact that legal guarantees of public control are complex, multifaceted phenomenon, which covers both general conditions and certain means of the mechanism for legal regulation that ensure the implementation of legally consolidated rights for human, citizen and other subjects of law in order to meet their needs and interests.

Despite all the complexity and multilayered nature of such a phenomenon like the law, in our opinion, one of the main reasons for the discussion and differences in the understanding of legal guarantees, including public control, is the ambiguity of the basic category, that is "guarantee".

The concept of "guarantee" in reference literature is defined like the guarantee in something; conditions that ensure success in something; providing something; obligation provided by law or certain agreement, under which any person is liable to creditors in case of non-fulfillment of his/her obligations (Busel, 2005, p. 222); defending something (Melnichuk, 1982); third party liability for the debtor's obligations and/or the seller's or manufacturer's liability to the buyer for hidden defects of the product, that is valid for a certain period of time (Popovych, 2006). The above-mentioned ambiguity leads to differences in the understanding of guarantees by modern lawyers. In particular, O. F. Skakun defines legal guarantees as freedoms and responsibilities of person and citizen as the system of conditions, means and methods (social and economic, moral, political, legal) that ensure their actual implementation, defense and reliable protection (Skakun, 2001, p. 187). On the contrary to O. F. Skakun, N. M. Onishchenko and O. V. Zaychuk consider relevant guarantees as the system of norms, principles and requirements that ensure the process of human rights and legitimate interests observance (Zaychuk. \& Onishchenko, 2008, p. 105). Instead, K. Ya. Siokh believes that today these guarantees are any legal phenomena provided, on condition that they help to realize fundamental rights and freedoms of person and citizen, and to implement them into life (Siokh, 2018, p. 379).

In our opinion, such a situation does not contribute to the streamlining of the conceptual and categorical apparatus of legal science and the achievement of unity of views on the concept of "guarantees", including "legal guarantees".

To our opinion, it should be noted that any definition of guarantees and, in particular, legislative ("legal guarantees", "juridical guarantees", "guarantees of law", etc.) without any exception, should cover all aspects of its general comprehension. 
Thus, as an intermediate conclusion, we note that while defining the concept of "legal guarantees" and other related concepts, it is advisable to proceed from the fact that they provide the following: guarantee in something; conditions that ensure success in anything; securing something under a legal or contractual obligation; third party liability for the debtor's obligations, etc.

At the same time, it should be noted that legal guarantees are one of the manifestations of law, which is designed to ensure its effect and make enable the achievement of the social effect (purpose of legal regulation), which is planned by the legislator during the adoption of the law.

For these reasons, it seems that the most accurate way to reveal the nature of legal guarantees is possible with the help of instrumental theory of law, namely by its key concept of "legal means". After all, within the framework of this theory, law is considered as the system of legal means that while joining into certain mechanisms and modes, they are programming effective solutions to problems in social, economic, political and other spheres of society (Hanzenko, 2016, p. 38).

In the most general sense, according to 0 . V. Onufrienko, legal means are being the system of substantial and active legal phenomena that through the instrumental game help relevant subjects of legal relations to satisfy their private and public interests (Onufrienko, 2004, p. 15).

A. M. Denisova puts similar meaning into the concept of legal means. However, the scientist notes that substantial means are obligations, permits, prohibitions, incentives, benefits, rules of law, principles of law, etc.; and effective ones are the acts of law implementation, acts of law enforcement, acts of interpretation of law, as well as all processes of legal activity (Denisova, 2012, pp. 9-13).

At the same time, N. V. Zayats emphasizes that legal means are primarily the system of substantial phenomena of legal reality on different levels, which have a certain functional focus on solving social problems. In addition, the scholar notes that legal means can be considered in two aspects: legal (legal instruments and formalized results of the subjects' activity) and social (normative expression on the values of law, certain interests, etc.) ones (Zayats, 2016, p. 205).

It follows that legal means are directly related to the rules of law, as well as regulations, in which they find their expression. The necessary social effect is achieved only through the system of legal means. Instead, the phenomena of legal reality like law enforcement, rulemaking, other legal activities, including legal awareness, and legal culture are exclusively the manifestation of the application and use of legal means not being part of them.

Taking into account the above mentioned, legal guarantees can be defined as follows: legal means that ensure actual implementation, protection and defense of human rights and freedoms for citizens and other legal entities in order to satisfy their needs and interests that are consolidated into the regulation system.

Examining the issues of guarantees on public control, including legal ones, domestic legal scholars reveal some aspects of the relevant issues only.

For example, I. O. Skvirsky investigated a separate element of the system of guarantees on public control, namely the principles of community control. In particular, according to the scientist's opinion, this is the principle of construction and organization of public control 
that guarantee the existence of relevant legal institution; they lay necessary foundation for the functioning of public control and its further regulation. According to I. O. Skvirsky, the principle of the Supremacy of the Law occupies central place among the principles of public control. In particular, the author emphasizes upon the importance of the principles on hierarchical S Supremacy of the Law and public (state) governance, which are also important elements of the legal form of public control (Skvirsky, 2013, pp. 182-186).

From our side, we have to note that, despite the unconditional theoretical interest, I. O. Skvirsky's reasoning reveals only the ideological aspect of guarantees on public control, including legal ones, and it does not allow to formulate a holistic view onto this complex and multifaceted phenomenon.

O. D. Tereshchuk has defined the concept of legal guarantees on public control as follows. According to this scientist, legal guarantees on public control are systematic set of means, methods and conditions reflected in regulations adopted by authorized state bodies, which regulate and ensure activities of civil society institutions in this field by some other ways (subjects of public control), i. e. through active monitoring of these controlling entities, by public authorities and local governments activities in order to ensure implementation of legitimate rights and interests of certain persons, as well as mentioning their defense and protection (Tereshchuk, 2018, p. 176).

As for the legal guarantees being external form of expression of legal guarantees, the value of the scientific work of 0 . D. Tereshchuk for comprehensive understanding of the issue of guarantees on public control (including legal) is beyond doubt. At the same time, we consider it necessary to note that the definition of this researcher needs to be refined, since the activities of civil society institutions are not limited to observation. It may include inspections of controlled entities, public expertise, public consultations (Gurzhii, 2017), and other forms of public oversight.

In turn, S. G. Stetsenko distinguishes general guarantees of control over the observance by the public administration of human and civil rights and freedoms. The scientist understands them as the legal means that allow to observe activities of public administration in order to identify illegal decisions, actions or omissions (Stetsenko, 2007, p. 195).

The essence of the guarantees on public control, according to S. G. Stetsenko, is not directly disclosed. However, bearing in mind that the scholar puts the general guarantees on control over the observance by the public administration of human and civil rights and freedoms onto the public; his scientific conclusions relate to one aspect of the issues of guarantees on public control. At the same time, the debatable points of the definition on general guarantees of control proposed by S. G. Stetsenko are as follows: reduction of subjects' activity of public control exclusively to observation, although, as we have already mentioned, there are other forms of such an activity; identification of the purpose of public control and the purpose of guarantees on public control.

The question of the purpose of guarantees on public control needs some clarification. This is primarily because the meaning of the terms "purpose of public control" and "purpose of guarantees on public control" to some extent overlaps, however, it is not identical. We have already noted about the purpose of public control as a key feature of community control, exploring legal nature of public control. In particular, we have established that the 
purpose of public control is, firstly, the results obtained as circumstances of public control subjects' activities, namely the performance of certain tasks of this control. Developing the conclusions proposed above, we are going to try and define the purpose of guarantees on public control more clearly.

Thus, the functional outcomes of public control should be considered as full public participation in public administration, improving the efficiency of public authorities, promoting the formation of civil society in Ukraine, building partnership between state and society. The relevant results and tasks of public control that mediate them are nothing but the needs and interests of the subjects of public control. Basing on these considerations, we consider that the result of the function (purpose) of the guarantees on public control is primarily to ensure the right to exercise public control.

S. M. Khomov was one of the few scholars who attempted to define the concept of legal guarantees on public control. However, public control is considered by this scientist at a purely institutional level (namely, at the level of the SFS operating in Ukraine), which could not but leave a "scar" on the author's definition. Thus, according to S. M. Khomov, legal guarantees on public control are the system of legal means by which rights and obligations of public control subjects and SFS of Ukraine are consolidated; the conditions for their realization and exercising public control over the activities of this service in this sphere are created. At the same time, the researcher refers to the guarantees as to forms of public control, in particular public hearings, public expertise, and public participation in the work of collegial bodies at public authorities (Khomov, 2016, p. 123).

In general, while positively evaluating S. M. Khomov's attempt to define the concept of legal guarantees (the definition traces the connection between rights and obligations), it should be noted that the definition proposed by him is debatable. This is primarily because the author levels together concepts like the means with the forms. This identification is incorrect, because the relevant concepts do not coincide in scope. In particular, we adhere to an approach in which legal forms are correlated with legal means as the part and the whole thing (Zayats, 2016).

The analysis of scientific and legal research in the field of legal guarantees on public control gives grounds to assert that today there is no clear and unambiguous understanding of the essence of legal guarantees on public control. As a rule, domestic scholars consider such guarantees only in the context of general issues on public control, without resorting to their thorough analysis. The same individual researchers who try to give at least a general description of the relevant guarantees or identify them with legal guarantees, or consider public control in a functional aspect only (i. e. in the meaning of organizational and legal institution or mechanism). Instead, guarantees on public control as human rights are ignored.

\section{CONCLUSIONS}

Taking into account the above mentioned, as well as when basing on the dualistic essence of public control as human rights, organizational and legal mechanism for its implementation, the concept of legal guarantees on public control can be defined as follows: the regulation system of means that ensures real implementation, protection and defense of the right to 
carry out public control, consolidated in normative and legal acts, in order to form civil society, social participation in public administration, increase the efficiency of public authorities, as well as building up partnership between state and society.

\section{REFERENCES}

Beloziorov E. V. (2017). Legal Guarantees: Modern Approaches to Juidical Understanding: Proceedings of the 2017 Conference "Law Enforcement: History, Current Status, Prospects (pp. 22-24). Kiev, Ukraine: National Academy of Internal Affairs of Ukraine.

Busel V. T. (2005). Reference Dictionary of Modern Ukrainian Language 250,000 (VIII). Kiev: Perun, 1728 p. Dakhova I. I. (2014). Citizen Participation in Administration of Public Affairs: Questions of Theory and Practice. Forum of Law, 3. pp. 102-109. Retrieved from: http://nbuv.gov.ua/UJRN/FP_index.htm_2014_3_18. Denisova A. M. (2012). Mechanisms and Means of Legal Influence (Theoretical and Legal Research). PhD Dissertation. Kiev: National Academy of Internal Affairs of the Ministry of Internal Affairs of Ukraine, $230 \mathrm{p}$. Gurzhii T., Goncharuk S., Kuzmenko O., Berlach A., Yarmaki K. (2020). Establishment of the Institute of Administrative Responsibility in the Legal System of Ukraine. Journal of Law and Political Sciences, 2/C, 235-260.

Gurzhii T., Gurzhii A., Seliukov V. (2018). Public Administration of Personal Data Protection in Modern Ukraine. Politické vedy, 21 (2), 138-15.

Gurzhii T. (2017). Public Consultations in Ukraine: Topical Legal Issues. Rocznik Administracji Publicznej, 3, 309-318.

Hanzenko 0. O. (2016). Theory of Legal Means in the Context of Instrumental theory of Law. Bulletin of Zaporizhia National University, 3. pp. 36-42. Retrieved from: http://nbuv.gov.ua/UJRN/Vznu_Jur_2016_3_7. Ishchuk, S. (2018). Selected Problem Aspects of the Implementation of Public Control in Ukraine. ScienceRise: Juridical Science, 4 (6). pp. 15-19. https://doi.org/10.15587/2523-4153.2018.153482. Karmaza O. O., Sarana S. V., Fedorenko T. V., Gurzhii T. O., Nefedova A. V. (2018). The Protection of Civil Rights and Interests in the Court. Journal of Advanced Research in Law and Economics, 9(8), 262-263.

Khomov S. M. (2016). Administrative and Legal Principles of Public Control over the Activities of the State Fiscal Service of Ukraine. PhD Dissertation. Kyiv: National University of Life and Environmental Sciences of Ukraine, $201 \mathrm{p}$.

Konstytutsiia Ukrainy. Data onovlennia 01.01.2020. Retrieved from: https://zakon.rada.gov.ua/laws/ show/254\%D0\%BA/96-\%D0\%B2\%D1\%80\#Text.

Melnichuk O. S. (1982). Etymological Dictionary of the Ukrainian language: In 7 vols. Vol. 1: AG. Retrieved from http://surl.li/znpa.

Mrówczyński M., Knepka T., Hurzhii T., Gurzhii A. (2020). Prawo publiczne wobec aktualnych problemów społecznych i gospodarczych. Poland: Bydgoszcz, 312.

Nikolaeva L. V., Gurzhiy T. O. (2021). Theory of State and Law: Textbook. Kyiv: Kyiv National University of Trade and Economics, $424 \mathrm{p}$.

Onufrienko O. V. (2004). Legal Means in the Context of Instrumental Theory of Law. PhD Thesis. Kharkiv: National University of Internal Affairs, $18 \mathrm{p}$.

Orel Yu. L., Smaglyuk A. A. (2018, April). Civic Participation and Public Control as a Mechanism for Improving the Quality of Public Services in Ukraine: Proceedings of the XVIII Conference "International Science Congress of Public Administration of the XXI Century: World Practices and National Perspectives" (pp.82-85). Kharkiv, Ukraine: HarRI NAPA Publishing House "Master".

Petryshyn O. V., Pogrebnyak S. P., Smorodynsky V. S. (2014). Theory of State and Law: Textbook for Students. jurid. higher ed. est. textbook. Kharkiv: Law, 368 p. 
Popovich M. V. (2006). Universal Dictionary-Encyclopedia (4 $4^{\text {th }}$ ed.). Lviv: TEKA, 1432 p. Retrieved from: http://surl.li/znqj.

Shaulskaya G. M. (2019). Some Modern Mechanisms of Cooperation Between Government and Civil Society in Ukraine: Efficiency Analysis. Scientific Notes of the Institute of Legislation of the Verkhovna Rada of Ukraine, 2. https://doi.org/10.32886/instzak.2019.02.19.

Siokh K. Ya. (2018). Legal Gguarantees of the Constitutional Right of Citizens of Ukraine to Civil Service in the Conditions of Modern Reforms. Retrieved from: https://scholar.google.com.ua/ citations?user=PvdVc4UAAAAJ\&hl=ru.

Skakun O. F. (2001). Theory of the State and Law: Textbook. Kharkiv: Consumption, 656 p.

Skvirsky I. O. (2013). Public Control in Public Administration: Theoretical, Legal and Praxeological Aspects. PhD Dissertation. Zaporizhia: Zaporizhia National University, 413 p.

Stetsenko S. G. (2007). Administrative Law of Ukraine: Textbook. Kiev: Attica, 624 p.

Tereshchuk O. D. (2018). Administrative and Legal Principles of Public Control over Theelaw Enforcement in Ukraine: Theory and Practice: Monograph. Kyiv: SE "Ed. house "Staff", 460 p.

Zayats N. V. (2016). Essential Charcteristic of Legal Means in the Mechanism of Legal Regulation. Entrepreneurship, Economy and Law, 12. pp. 202-205. Retrieved from: http://nbuv.gov.ua/UJRN/ Pgip_2016_12_38.

Zaychuk O. V., Onishchenko N. M. (2008). Theory of State and Law: Textbook, $2^{\text {nd }}$ ed., Revised. and ext. Kiev: Jurinkom Inter, 688 p. 


\title{
CONSTITUTIONAL STATUS OF NATIONAL MINORITIES IN ROMANIA
}

Eugen Chelaru, University of Pitești, Prof. PhD hab., Faculty of Economic Sciences and Law, Bld. Republicii, no. 71, Pitesti, Romania chelaru.eugen@gmail.com

Andra Puran, University of Pitești, Lecturer, PhD, Faculty of Economic Sciences and Law, Bld. Republicii, no. 71, Pitesti, Romania https://orcid.org/0000-0002-8773-1548

*andradascalu@yahoo.com

\begin{abstract}
There is no purely ethnic state in Europe, so the constitutional regulation of the tatus of minorities is a necessity. The Constitution of Romania, within the general principles of the constitutional system, regulates the right to preserve, develop and express the ethnic, cultural, linguistic and religious identity of national minorities. These regulations set out the framework within which other constitutional provisions relating to the status of such persons and the general limits imposed to the legislator in defining it, should be laid down.
\end{abstract}

Keywords: national minority, ethnicity, migration, identity, electoral rights.

\section{INTRODUCTION}

Like most other European states, Romania was born at a time when the idea of a national state had not yet prevailed in public international law. Although the Romanian ethnic groups have always been the majority, historical circumstances have generated changes in the population structure, including through territorial changes, which have led to the emergence of a significant mass of people belonging to other ethnic groups, with whom they lived. The need to protect the identity of minorities and the recognition of specific rights leading to this result was a long process, influenced by historical events and the evolution of political ideas.

The Romanian state was founded on January 24, 1859, as a result of the union of the principalities of Wallachia and Moldavia, under the name of the United Principalities of Moldavia and Wallachia, which included less than half of the territories inhabited by Romanians, but also a large number of minorities, especially Jews. The first Constitution of Romania, adopted in 1866, made no reference to citizens belonging to national minorities (Iancu, 2014). In fact, the authorities did not even use the term "minorities", the inhabitants of Romania being divided into two main categories: Romanians and foreigners. Foreigners also formed two categories - those who were "foreign subjects", i.e. those who had the 
citizenship of a foreign state and those without any citizenship.

The end of the First World War, which fundamentally changed not only the political architecture of Europe, but also the conceptions about the status of minorities, brought great changes in Romania, a state in the camp of the victors. Thus, the year 1918 is marked by the process of union with Romania of most of the territories inhabited by Romanians: Bessarabia (territory occupied by Russia), Bukovina, Banat, Crișana, Maramureș and Transylvania (territories occupied by the Austro-Hungarian Empire, which disintegrates). Although the Romanians were the majority in all these historical provinces, they were accompanied by a large number of people belonging to other ethnic groups, especially Hungarians, Germans, Ukrainians, Russians and Jews (Bălan, 2018). Such a change in ethnic composition was foreseeable, so at the Paris Peace Conference (1919-1920), the "Treaty concluded between the Main Allied Powers and Romania on the protection of minorities and trade relations" was negotiated and signed (Bălan, 2018).

In 1923 a new Constitution was adopted, which also attaches great importance to the rights of national minorities. National minorities were represented in Parliament and participated in the debate on the draft of the new Constitution, which will proclaim equality before the law of all Romanian citizens will provide that the distinction between religious beliefs and denominations, of ethnic origin and language, acquire civil and political rights and exercise them. However, the rights belonging to citizens who were part of national minorities were enshrined mainly in "fundamental" (organic) laws. For example, in electoral matters, the law gave some privileges to national minorities in terms of how to assign seats, so as to ensure their representation in Parliament, and religious cults recognized by the state were legally represented in the Senate (Ionescu, 2018).

Even if after the Second World War the structure of the population in Romania changed, especially as a result of the occupation by the Soviet Union of Bessarabia and northern Bukovina, the Constitutions adopted by the communist power in 1948, 1952 and 1965 also contained provisions proclaiming equality in rights with Romanians of citizens belonging to national minorities.

According to the 2011 census, the population of Romania was 20.121 .641 people, of which 88,9 \% Romanians, 6,5 \% Hungarians, 3,3 \% Roma (Gypsies). Ethnic groups larger than 20,000 people registered only Ukrainians, Germans, Turks, Russians and Lipovans, Tatars.

\section{PURPOSE, MATERIALS AND METHODS}

The present study aims to analyze in general terms the constitutional status of national minorities in Romania. All Romanian citizens have fundamental rights provided by the Constitution and which are based on international regulations. In addition to these rights, national minorities also enjoy specific fundamental rights.

To achieve this goal, several methods of scientific research are combined, respectively: the logical method, the comparative method, the historical method, as well as the study of documents, the paper falling within the scope of constitutional law. The study has an interdisciplinary character considering the sources of documentation belonging to various fields: constitutional law, international law, general theory of law. The realization of the paper was based on the traditional bibliographic documentation, but also on the direct 
documentation through the analysis of the international and constitutional dispositions in the field.

\section{The notion of national minority}

There is no unanimously accepted definition of national minorities in international law. The most important attempts to define this notion were made under the auspices of the United Nations, commissioning three studies, conducted by F. Capotorti in 1971, J. Deschenes in 1984 and M. Corbo in 1986. The definition given by F. Capotorti it is the starting point for other definitions given at the doctrinal level and is based on numerical and sociological criteria. Capotorti defined the minority as "a group numerically inferior to the rest of the population of a state, in a non-dominant position, whose members, being citizens of the state, possess ethnic, religious or linguistic characteristics that differ from those of the rest of the population and show, even if only implicitly, a spirit of solidarity, in order to preserve their culture, traditions, religion or language" (Lajoie, 2002).

The definition developed by M. J. Deschenes (Selejan-Guțan, 2008) evokes the same essential elements, based on an objective and a subjective criterion. The objective criterion takes into account the numerical inferiority, the non-dominant character of the group, distinct characteristics regarding ethnicity, religion or language and the existence of a sufficiently large number to preserve the characteristics. From a subjective point of view, the desire to keep the specific characteristics, solidarity but also the feeling of belonging to that group are taken into account.

The most important European attempts to define national minorities are identified in the Recommendation 1134 of the Parliamentary Assembly of the Council of Europe on the rights of persons belonging to national minorities, adopted on October 10, 1990 and in Recommendation 1201 of the Parliamentary Assembly of the Council of Europe of February 01, 1993. According to point 11 of Recommendation 1134, national minorities are "separate or distinct groups, well defined and established on the territory of a state, the members of which are nationals of that state and have certain religious, linguistic, cultural or other characteristics which distinguish them from the majority of the population". Recommendation 1201 of the Parliamentary Assembly of the Council of Europe on February 01, 1993 considers those who: a) reside on the territory of a state and are its citizens; b) maintain long-term, lasting and permanent ties with that State; c) display distinct ethnic, cultural, religious or linguistic characteristics; d) are sufficiently representative, even if they are smaller than the rest of the population of a state or a region of that state; e) are motivated by the concern to keep together what constitutes their common identity, including their culture, traditions, religion or their language (Duminică\&Aleca, 2010).

These definitions have been criticized for either covering only one of the meanings given to the notion of national minority, in the sense that they refer only to minorities made up of nationals of the state in which the group has acquired the status of "ethnic minority" (Prisacariu, 2010), or a definition should start from the sociological to the political criterion (Dănișor, 2003).

The recent migrations, especially to Western countries, generate complex ethnocultural, linguistic, religious, economic and political differences, which gives legitimacy to the question 
of whether the status of "national minority" should not be granted to "new minorities" of immigrants, even if they do not "maintain long-term ties" with that state, have not acquired citizenship or the right of permanent residence and do not meet all the other criteria to be considered a "national minority".

Romanian legislation does not define the analyzed notion, but in the Treaty of Friendship, Cooperation and Good Neighborhood with Hungary (1996), as well as in the Treaty on Cooperation and Good Neighborhood Relations between Romania and Ukraine (1997), reference is made to Recommendation 1201 of the Parliamentary Assembly of the Council of Europe of February 01, 1993. The treaties being ratified by the Parliament, it can be said that, based on Art 11 of the Romanian Constitution, the definition contained in this Recommendation has acquired normative value internally.

\section{Subjects of law benefiting from the status conferred on national minorities}

Who benefits from the rights granted to national minorities - the people who belong to these communities or the ethnic groups to which they belong?

We believe that the answer must be nuanced.

On the one hand, not every ethnic group that is different from the majority population can be qualified as a national minority, but only the one whose existence is recognized by law. On the one hand, once the existence of the national minority is recognized, the question arises on determining the natural persons who form it, because only they can hold certain rights. Recommendation 1134 refers to "the rights of persons belonging to national minorities" and not to "the rights of national minorities".

Two criteria can be used to determine a person's membership in a minority - the objective criterion, based on distinct ethnic, cultural, religious or linguistic characteristics, and the subjective criterion, based on the person's will to belong to that minority. The Romanian Constitution favors the subjective option, stating that discriminatory legal treatments or legal privileges should not be created for persons depending on the sociological criteria that place them in a minority, while stating the need to preserve the identity of these persons without necessarily placing them in a minority. based on their will (Dănișor, 2010).

The recognition of special rights is therefore addressed to citizens viewed individually, and not to groups of citizens, and cannot lead to territorial autonomy on ethnic grounds. The number of members forming a certain national minority can only be a criterion according to which a right may or may not be granted.

The Constitutional Court had the opportunity to rule on such an issue by Decision No. 80/2014 (published in the Official Gazette of Romania, Part I, No. 246/7 April 2014), when it examined a legislative proposal to revise the Constitution. According to this proposal, Art 3 is supplemented by Para $3^{1}$, according to which "Traditional areas may recognize traditional areas as administrative subdivisions of regions". It was declared unconstitutional, the Court invoking several arguments.

The inaccuracy of the tradition criterion, which was proposed for the recognition of the new administrative-territorial units, was noted and it was found that it is not specified what relations would be established between the new administrative subdivisions and the existing administrative-territorial units. The Court also noted that the proposed text "induces the 
idea of territorial autonomy of some population groups" only on the basis of the identity of traditions, which "affects the administrative organization, economy, taxation, through the possibility of autonomous bodies to enact mandatory rules for members community". In this way, the unitary character of the Romanian state is affected, an aspect that cannot be the object of a revision of the Constitution, according to Art 152, Para 1.

\section{The main rights specific to national minorities regulated by the Romanian Constitution}

The Romanian Constitution (adopted in 1991 and revised in 2003) uses the phrase "national minorities", although during the debates of the Constituent Assembly on the draft constitution the issue of using the phrase "ethnic minorities" was raised. However, it was objected that "ethnicity expresses a predominantly biological relationship, while belonging to a national minority expresses something more, a social-political, cultural, spiritual relationship, and so on. The national minority is therefore a proximate gender category, while the ethnic minority is a specific difference, absorbed in the proximate gender of the national minority" (Deleanu, 1998).

Like the relevant international regulations, the Romanian Constitution regulates the status of national minorities, enshrining the individual rights of persons belonging to these minorities.

\subsection{The right to identity}

The provisions of Art 6 of the Romanian Constitution regulates the right to ethnic, cultural, linguistic and religious identity of persons belonging to national minorities, in conditions that do not discriminate against other Romanian citizens. These constitutional provisions constitute the common law on the protection of persons belonging to national minorities, outlining the general framework within which the legal provisions determining their status must be situated.

The Constitutional Court referred to the principles of equality and non-discrimination in relation to other Romanian citizens by Decision No 80/2014, cited above. It was proposed that two new paragraphs be added to Art 6 of the Constitution, according to which the legal representatives of national minorities were empowered to set up their own decisionmaking and executive bodies, with competences on the right to preserve, develop and express their identity and central public authorities. and local organizations were obliged to consult national minority citizens' organizations before making decisions on the preservation, development and expression of their ethnic, cultural, linguistic and religious identity.

The Court found that the first paragraph contravenes Art 1 of the Constitution, which enshrines the unitary character of the Romanian state, because the essence of such a state "is the existence of a unique set of institutions with political decision-making power". The creation of its own decision-making and executive bodies would have the consequence of achieving a collective political autonomy based on ethnic criteria. At the same time, privileges would be granted to national minorities, which is contrary to Art 6 Para 2 of the Constitution. 
Regarding the obligation of central and local public authorities to consult the organizations of citizens belonging to national minorities in matters concerning them, the Court recalled that regulating the ways in which the state guarantees the right to identity of national minorities is not within the scope of the Constitution but of the law (Constitutional Court, Decision No 799/2011, published in the Official Gazette of Romania, Part I, No 440/23 June 2011) that this contradicts "the principles of equality and non-discrimination against other Romanian citizens".

The constitutional right to identity has as its object different forms of identity: ethnic, cultural, linguistic and religious.

3.1.1. Ethnic identity is a difficult concept to define given that the features of the ethnic group aim at the use by its members of a distinct language or a common culture, different from that of the majority of the population. However, both cultural and linguistic identity are guaranteed separately from constitutional norms. In this context, it was shown that "ethnic traits are evolutionary, aspects of identity erected in ethnic traits depending on the type of opposition perceived by group members as essential at a given historical moment and in a particular conjuncture ... being forbidden to both the legislator and the Constitutional Court to use general definitions of the content of this right, which would limit in an abstract and general way the ethnic identity to certain particular features" (Dănișor, 2009).

The right to identity is exercised and is protected in conditions of equality and nondiscrimination against other Romanian citizens. Both the ethnic groups and the majority citizens, as well as the ethnic groups between them, are situated on an equal footing, being implicitly forbidden a hierarchy of ethnicities.

Ethnic identity is not an internal matter of the group but it delimits the members of the group from the other groups, assuming the right to identify as belonging to an ethnic group through features that the group considers defining for its identity.

3.1.2. Cultural identity as part of minority identity, implies the right to preserve the beliefs, customs, traditions, specific creations that belong to the spiritual heritage of the minority, but also the right to create cultural associations that promote and preserve cultural traditions.

Internationally, the term "culture" is defined as "values, beliefs, beliefs, languages, knowledge and arts, traditions, institutions and ways of life through which a person or group expresses its humanity and the meanings it gives to existence and development", while cultural identity is defined as" a set of cultural references by which a person, alone or in common, defines, constitutes, communicates and understands to be recognized in his dignity" (Art 2 Let a)-b) of the Fribourg Declaration on Cultural Rights, 2007).

In the Romanian doctrine it is considered that the constitutional regulation of Art 6 regarding cultural identity is interpreted "in the sense that the universality of cultural values, as general human values, must be expressed through diversity, just as diversity must be put at the service of universality, of general human values" (Dănișor, 2010).

3.1.3. Linguistic identity of persons belonging to national minorities is recognized in order to guarantee their right to preserve their identity through language and not to create linguistic diversity within the state. Moreover, the Romanian Constitution expressly provides that the official language is Romanian (Art 13). The right to linguistic identity 
is an individual right that implies the free use of languages in the private sphere, except in situations expressly provided for by constitutional rules, situations in which minority languages may be used in relations with local administrations or in justice.

3.1.4. Religious identity is constitutionally guaranteed to all persons by regulating the fundamental right to freedom of conscience (Art 29 of the Romanian Constitution). Often, however, a particular religion is practiced especially by members of an ethnic community.

Freedom of religion, as part of freedom of conscience, involves both the externalization of a faith, religion, and the freedom to adhere to a religious organization and ritual practiced. It is necessary that the religion or religious organization be recognized by law and the activity of a certain religious cult is not considered as contrary to the rule of law or good morals (Andreescu\&Puran, 2018). Religious cults are autonomous from the state and are organized according to their own statutes, in accordance with the law. It was decided that the autonomous existence of religious communities is indispensable in a democratic society and is an essential issue in the protection of religious freedom (Constitutional Court Decision No 448/2011, published in the Official Gazette of Romania, Part I, No 424/17 June 2011).

Freedom of conscience also implies the freedom to belong or not to any religion, which is why the Constitutional Court has ruled that the legislator has an obligation of neutrality and impartiality. This obligation is fulfilled in the situation where the state ensures the observance of these freedoms, consecrating, among others, the possibility of parents, legal representatives of minor students and, respectively, the possibility of adult students to request participation in religious classes (Constitutional Court Decision No 669/2014, published in the Official Gazette of Romania, Part I, No 59/23 January 2015).

\subsection{The right to learn and use one's mother tongue}

The right of persons belonging to minorities to learn and use their own language is closely related to the right to linguistic identity and cultural identity and is regulated in several constitutional provisions: Art 32 Para 3 (right to education), Art 120 (basic principles of local public administration) and Art 128 Para 2-3 (use of mother tongue and interpreter in court).

The organization and development of education must be done in the official language of the state, in the case of Romania the Romanian language, but the Constitution guarantees the right of persons belonging to national minorities to learn in their mother tongue and the right to be trained in this language. In order to guarantee the right to education in the mother tongue, a special body has been created within the Romanian Government - the Minorities Directorate, which "coordinates the implementation of the development and reform strategy in education for national minorities and aims at continuously aligning the quality of education for minorities. to the performance standards of the countries of the European Union". The Romanian state has also developed a Methodology on the study of the mother tongue and mother tongue and literature, of the Romanian language and literature, the study of the history and traditions of national minorities and of music education in the mother tongue, as a legal instrument guaranteeing the fundamental right. to education in the mother tongue. 
The 2003 constitutional revision granted, through Para 2 of Art 120, the possibility of using the languages of national minorities in relation to local public administration authorities, thus extending the use of these languages in public life. The quoted text stipulates that "in the administrative-territorial units in which the citizens belonging to a national minority have a significant share, the use of the language of the respective national minority is ensured in writing and orally in the relations with the local public administration authorities and with the deconcentrated public services under the conditions provided by the organic law". These constitutional provisions have been intensely criticized in the literature, considering that they violate the constitutional provisions of Art 4 which enshrines the unity of the people, prohibiting collective rights and the provisions of Art 13 which enshrines the Romanian language as an official language (Gîrleșteanu, 2010).

The special legislation (Law 215/2001 on local public administration, republished in the Official Gazette of Romania, Part I, No 123/20 February 2007) stipulates that public administration institutions can only use the Romanian language and official documents are written only in the official language, i.e. in Romanian, but also regulate the conditions and ways in which the languages of national minorities can be used. Thus, the use of mother tongues in relations with the public administration is allowed if the speakers of a minority language exceed the limit of $20 \%$ at the level of the administrative-territorial unit, the citizens being able to address and receive answers (both orally and in writing) in that language; this language may be used during meetings, hearings or other debates in the local Council, provided that the number of councilors belonging to a national minority represents at least one fifth of the total number of councilors, the decisions thus being taken being communicated in the minority language; local normative acts can be translated into the minority language and individual acts are communicated, upon request, in the mother tongue; the names of some institutions or localities, as well as the announcements of public interest are also inscribed in the mother tongue; certain public or private ceremonial events (for example, the marriage ceremony) may take place in the minority language (Prisacariu, 2010).

Also, the Romanian Constitution provides in Art 128 the possibility of using the mother tongue in court, while establishing limits to this right. The modalities for exercising the right to use the mother tongue, including through the use of interpreters or translations, shall be established in such a way as not to impede the proper administration of justice and not to involve additional costs for those concerned.

The doctrine considered the constitutional regulation analyzed to be excessive, showing that no fundamental law in European countries contains such a provision and, moreover, the European Convention on Human Rights and the International Covenant on Civil and Political Rights do not contain provisions on in the language used before the courts, but establishes only the obligation to provide a free interpreter, if necessary, especially in criminal matters.

\subsection{The specifics of electoral rights}

Regarding the electoral rights, Art 62 Para 2 of the Romanian Constitution provides that “citizens' organizations belonging to national minorities, which do not meet in elections the number of votes to be represented in Parliament, have the right to one seat each, under the 
conditions of the electoral law. Citizens of a national minority can only be represented by one organization". This regulates the way in which Romanian citizens belonging to national minorities participate in the exercise of state power through a representative body.

The Constitution does not limit the electoral rights of citizens belonging to national minorities in relation to those of majority citizens, but, on the contrary, provides a privilege if the organizations of citizens belonging to national minorities do not meet in the elections the number of votes to be represented in Parliament. Thus, acquiring a seat in the Chamber of Deputies, if they obtained, throughout the country, a number of votes equal to at least $5 \%$ of the average number of valid votes cast in the country for the election of a deputy.

The implementation of these constitutional provisions led to the establishment in the Chamber of Deputies of a parliamentary group consisting of 18 representatives of national minority organizations currently operating in Romania.

\section{CONCLUSIONS}

The citizens who have the distinctive features able to place the group they form in the category of national minority are a component part of the Romanian nation. The Constitution regulates and guarantees fundamental rights whose beneficiaries are all Romanian citizens, without offering privileges to Romanian ethnics. However, there is no denying that, although they do not have a dominant status, Romanians feel much more comfortable than minorities in a state that bears the name of the people of which they are part and whose official language is Romanian. Even if we take into account only these aspects, we can understand why it is necessary for persons belonging to national minorities to be granted additional rights, meant to guarantee their preservation of identity and assertion in public life, even if it leads to positive discrimination in relationship with the majority.

At the same time, the Constitution grants these additional rights to individuals, and not to certain communities. They benefit equally the people who live in compact groups, which may be the majority in some parts of Romania, and those who are dissipated in the large mass of the population. In order to avoid any confusion, it would be more appropriate to speak consistently about the rights of persons belonging to national minorities, and not about the rights of national minorities, although the latter expression is more concise.

The resurgence of the demands made by some groups of minority citizens in different states, which invoke the Kosovo precedent and claim either independence or ethnic autonomy, proves how difficult it is to maintain the balance between the unity and indivisibility of states, on the one hand, and the content and extent of the rights that can be granted to persons belonging to national minorities, on the other hand. Maintaining this balance is difficult especially when the current minorities were part of a dominant nation in a certain historical period, as is the case of Hungarians living in Romania and who show a tendency to enclave.

However, we appreciate that the provisions of the Romanian Constitution, developed through a well-articulated special legislation, are able to ensure this balance, if they are interpreted and applied in good faith, both by the authorities and by the beneficiaries. 


\section{REFERENCES}

Andreescu, M., Puran A., (2018). Drept constituţional. Teoria generală şi instituţii constituţionale. Jurisprudență constituţională, $3^{\text {rd }}$ Edition, Bucharest: C. H. Beck.

Bălan, M. (2018). Considerații în legătură cu drepturile minorităților în România Mare. Dreptul, 11.

Dănișor, D. C. (2010). Dreptul la identitate al persoanelor aparținând minorităților naționale. In: Dreptul la identitate, Bucharest: Universul Juridic.

Dănișor, D. C. (2009). Constituția României comentată. Titlul I. Principii generale, Bucharest: Universul Juridic.

Dănișor, D. C. (2003). Noțiunea de minoritate: de la definirea sociologică către definirea politică, Revista de Drept public 2.

Dănișor, Gh. (2010). Identitatea culturală. In: Dreptul la identitate, Bucharest: Universul Juridic.

Deleanu, I. (1998). Geneza Constituției României 1991, Bucharest: Official Gazette Press.

Duminică, R., Aleca C. (2010). Brief Considerations on Defining Concept of National Minority, Agora International Journal of Juridical Sciences, 1.

Gîrleșteanu, G., (2010). Limba oficială, limbile minoritare și administrația publică. In: Dreptul la identitate, Bucharest: Universul Juridic.

Iancu, Gh. (2014). Drept constituţional și instituţii politice, $3^{\text {rd }}$ Edition. Bucharest: C. H. Beck.

Ionescu, C. (2018). Desăvârșirea unității statale și naționale a României - un proces istoric obiectiv.

Dreptul 12.

Muraru, I., Tănăsescu, E. S. (2008). Constituţia României. Comentariu pe articole, Bucharest: C. H. Beck.

Prisacariu, M. R. (2010). Statutul juridic al minorităților naționale, Bucharest: C. H. Beck.

https://www.edu.ro/DirectiaMinorități

https://droitsculturels.org 


\title{
A DEMOCRATIC STATE GOVERNED BY THE RULE OF LAW - THE CONSTITUTIONAL IDENTITY OF THE CZECH REPUBLIC
}

\author{
Ondřej Preuss, \\ Charles University, Prague, \\ Faculty of Law, Senior Lecturer, Ph.D. \\ https://orcid.org/0000-0003-0779-8513, \\ The paper was prepared under the 'Progres 04' \\ programme of Charles University \\ preuss@prf.cuni.cz
}

\begin{abstract}
This article aspires to shed more light on the understanding of the notions of the constitutional identity, the material core of a constitution and unamendable elements of a constitution (eternity clauses) and on the concept of essential elements of a democratic state governed by the rule of law as reflected in the practice of the Czech Constitutional Court.

The Czech debate is not centred on the use of constitutional identity as a shield protecting local specifics. Quite the opposite. With a certain degree of generalization, we can conclude that the Czech notion of constitutional identity is, at least in the view of the Czech Constitutional Court, deeply grounded in such general concepts as democracy and the rule of law and connected with the material core of a constitution and unamendable elements of a constitution. However, this "legal“ concept of constitutional identity may easily conflict with a "popular" constitutional identity based primarily on traditional narratives about the formative events of Czech history as perceived by the Czech people and their elected representatives.
\end{abstract}

Keywords: the constitutional identity of the Czech Republic, the material core of a constitution, unamendable elements of a constitution, the eternity clause

\section{INTRODUCTION}

The Czech constitutional debate has long revolved around abstract terms such as the "material core" or „focal point" of the Constitution. Much discussion has taken place around which clauses in the Czech Constitution (if any) are unamendable or „eternal“ and constitute the essential elements of a democratic state governed by the rule of law. Such discussions can hardly avoid the concept of constitutional identity. As noted by Fabrini and Sajó, few concepts appear to be currently more à la mode among legal scholars than the notion of constitutional identity - a doctrine developed by apex state courts to generically shield areas of national legal systems from the influence of European law. Since 1992, Article 4 TEU has affirmed that the European Union shall respect member states' "national identities, inherent in their fundamental structures, political and constitutional, inclusive of regional and local self-government"(Fabbrini and Sajó, 2019, 457). 
Perhaps surprisingly, the Czech debate is not centred on the use of constitutional identity as a shield protecting local specifics. Quite the opposite. With a certain degree of generalization, we can conclude that the Czech notion of constitutional identity is, at least in the view of the Czech Constitutional Court, deeply grounded in such general concepts as democracy and the rule of law.

How have we arrived at this conclusion? The notion of constitutional identity is already well known to legal theory in a much broader sense (Ponthoreau, 2018), (Besselink, 2010), (Bogdandy and Sschill, 2011), (Mangoldt, 2002), (Sajó, 2019), (Faraguna, 2017). It has been analysed by Czech legal scholars, even though it has never stood in the centre of abovementioned debates (Grinc and Ondřejková, 2016). This article does not intend to address the question of whether or not the inclusion of the refined concept of respect for national identity in EU primary law via the Lisbon Treaty and its legal relevance significantly change the relationship between EU law and its national counterparts, although it is certainly possible to agree with Robert Zbíral that this relationship remains complicated and in many aspects, tense (Zbíral, 2014).

The purpose of this article is to demonstrate that, from the legal point of view, the Czech Constitutional Court identifies Czech constitutional identity with the ideals of the democratic rule of law, even though such a notion is conceptually inconsistent, and in fact somewhat self-contradictory. This is however the case, and despite its shortcomings, the approach also has undeniable positives in the current unstable post-pandemic world.

Czech constitutional identity in this legal sense of the term therefore really emerges from the belief that it is necessary to combine common historical experiences related to the past communist era and the necessity of building a democratic system after the collapse of the communist regime at the turn of the 1980s and 1990s.

It cannot however be concluded that the Czech constitutional identity is created merely by a specific mixture of solutions that are a legacy of the past, and solutions based on Western European patterns used as part of the political transformation, as President Havel's transnational ethos prevails over these influences.

However, as correctly pointed out by Kosař and Vyhnánek, this „legal“ concept of constitutional identity may easily conflict with a "popular" constitutional identity based primarily on traditional narratives about the formative events of Czech history as perceived by the Czech people and their elected representatives (Kosař and Vyhnánek, 2018). It is for a reason that we this year celebrate 100 year anniversary of the publication of Hašek's Švejk (Hašek, 1974), and that we last year did not celebrate 400 years from the defeat of the Bohemian Estates' army in the battle of Bílá Hora. The „Hungarian way“ therefore cannot be entirely ruled out and it may yet to prove that the constitutional identity might develop in a different direction than the one preferred by the Constitutional Court (Kosař and Vyhnánek, 2018, 868).

In order to understand what constitutes Czech constitutional identity in the legal sense of the term and in the rulings of the Constitutional Court, we must analyse other concepts; namely, the essential elements of a democratic state governed by the rule of law and the material core of the Constitution. 


\section{Material core of the Constitution and constitutional identity}

Lest a constitution be an empty shell, it must be filled with certain substance, which may be further divided into essential substance (which is crucial for the character of the constitution) and implementing substance (which elaborates on the basic principles). Just as a sales contract must include certain essential elements (essentialia negotii), such essential elements must also be present in the social contract, i.e., the constitution.

Formally, such essentialia negotii of the Czech Constitution are referred to as „essential elements of a democratic state governed by the rule of law“. They are however embedded in the Czech constitutional system only in Article 9(2) of the Constitution, which states that: Changes to the essential elements of a democratic state governed by the rule of law are not permissible. As Jan Filip reminds us, this express stipulation going beyond the original government-sponsored version of the Constitution was pushed through by President Havel. Jan Filip mentioned at the conference „20 years of the Czech Constitution“ that Václav Havel initially proposed to designate Articles 1 to 11 of the Constitution as essential elements of a democratic state governed by the rule of law. This was in the end rejected, partly due to fears of future interpretation problems foreshadowed by the German legal debate on a similar construction of the material core of German Basic Law embedded in Article 20 of the German Basic Law. It is however clear that any constitution contains certain essential elements or a material core without which it would no longer be the same constitution, even if no such provision is expressly stipulated in that constitution. Including such an express provision should however make the identification and delimitation of such unamendable elements easier.

However, since the concept is so broad and general and the Constitution does not offer any other normative guidelines for its interpretation, it is only natural that the interpretation of its true meaning evolves gradually through the body protecting constitutionality, the Czech Constitutional Court.

It is undisputed in legal theory that the above eternity clause on the essential elements of a democratic state governed by the rule of law is „inspired as to its ideological basis, wording and systemic placement in the constitutional system by Article 79(3) of the German Basic Law (1949), the „eternity clause“. (Ewigkeitsgarantie).“( Sládeček and Mikule and Syllová, 2007, 71).

The Constitutional Court uses the term „essential elements” interchangeably with the terms "material core" or "focal point" of the Constitution. It is beyond the scope of this article to closely analyse the differences between these two terms and they are therefore used herein as synonyms. According to the electronic databases of the decisions of the Constitutional Court (available at <http://nalus.usoud.cz/ $>$ ) the term „essential elements of the democratic state governed by the rule of law" appears in 175 judgments or resolutions of the Constitutional Court. The term „material core of the Constitution“ appears in scores of judgments and resolutions of the Constitutional Court. 21 judgments directly address the principle of the material rule of law. 10 judgments and 2 resolutions directly address the principle of eternity, while the principles of sovereignty of the people and the republican form of government were addressed by the Constitutional Court only in its „Lisbon judgments“. 
Decisions of the Constitutional Court however mostly refer to the material concept of the rule of law in a broader sense of the term, which is perceived by the Constitutional Court as a reflection of the notion of constitutional identity. According to the Constitutional Court, Czech constitutional identity does not refer to the glorious moments of Czech history, but rather to general guarantees of the democratic rule of law, or a constitutional democracy as such.

Acertain discrepancy can be identified here. According to the Constitutional Court, essential elements of a democratic state governed by the rule of law are identical to the material core of the Czech Constitution. Constitutional identity therefore equates to essential elements of the democratic rule of law.

Constitutional law theory however frequently understands the material core, hard core, or focal point of a constitution as a set of values which are characteristic for the given constitution (or constitutional system) (Holländer, 2005), which would be more consistent with the notion of constitutional identity than a general definition of essential elements of a democratic state governed by the rule of law further described below.

Pavel Molek writes that "the material core or focal point of the Constitution encompasses such rules which determine the very grounds of the constitutional system, i.e., they define the given constitution in such a sense that any change to them would result in an entirely different constitution and the existing constitution defined by them would no longer exist. Fusion of these two concepts into one, i.e., construction of the unamendable elements of a constitution in such a way that they are identical to its material core, is usually an unachievable ideal. (Molek, 2014, 138).

Every constitution should demark its territory, its people and how these people legitimize state power. This, according to Pavel Molek, constitutes the said „material focal point" of a constitution (Molek, 2014, 196).

It is therefore not possible to equate the material core of a constitution with essential elements of the democratic rule of law or unamendable constitutional provisions. A state may be a republic, monarchy, federation, or unitary state; it may be governed by a presidential or parliamentary system and such characteristics will be the defining elements of its constitutional system. They will however have no impact on whether the state is governed by the democratic rule of law, as these categories are entirely different.

Simply put, whether a state is a federation or a unitary state determines its very character (identity) but says nothing about its democratic fundaments. If we turn a monarchy into a republic, we will inevitably change the material core (focal point) of the state's constitution, while its democratic fundaments may remain completely unaffected.

The material core of the constitution therefore refers to constitutional identity, as understood by EU law, rather than the general principles of the rule of law, as illustrated by Judgement of the Court of Justice of the European Union (Second Chamber) of 22 December 2010. Ilonka Sayn-Wittgenstein v Landeshauptmann von Wien. C-208/09. In this case, Ms. Ilonka Sayn-Wittgenstein, an Austrian citizen residing in Germany was adopted by German citizen Lothar Fürst von Sayn-Wittgenstein and as a result acquired a name with the noble title of „Fürstin (countess) von Sayn-Wittgenstein“. This was initially registered in the Austrian register of civil status but following a decision by the Austrian constitutional 
court later replaced with a "civil“ surname of "Sayn-Wittgenstein“. With this ruling, the CJEU acknowledged that the EU does respect the national identity of its member states, which also includes the republican system of government. Gary Jacobsohn understands constitutional identity differently, as a sum of principles from which a given constitution should not deviate if it intends to retain stability in a society (Jacobsohn, 2010).

Constitutional identity may therefore be a slightly broader concept than the mere material core of the institution, which is a kind of extraction of only the most important features of a given constitutional identity. Should Austria permit the registration of a noble title into its register of civil status, that would represent an interference with its republican identity, but not necessarily with the material core of its constitution such as for example the restoration of the Austrian empire.

As stated above, the Constitutional Court of the Czech Republic makes a de facto equation not only between the material core of the constitution and constitutional identity, but also between these two concepts and the essential elements of a state governed by democratic rule of law, i.e., the Czech "eternity clause".

\section{Unamendable provisions and the „eternity clause“}

However, the unamendable or „eternal“ provisions in fact also belong to an entirely different category than the material core or focal point of a constitution. Their purpose is to rule out any changes to the principles, norms and values essential to the constitutional system of a given state. A typical example of such an eternity clause is Article 9(2) and (3) of the Czech Constitution.

The earliest known express eternity clause was embedded in the 1798 Constitution of the Swiss Helvetic Republic, which proclaims in the last sentence of Article 2: „Even if changed in the future, the form of government must forever remain representative democracy." Certain clauses in the constitution of post-colonial Delaware and New Jersey from 1776 could be considered even older predecessors of eternity clauses. However, since the Helvetic Republic emerged in the wake of a French invasion, it is not surprising that it ceased to exist after a mere four years along with its constitution. Besides representative democracy one of the main defining features of the Helvetic Constitution was strong central government both of which are in direct opposition to what has Switzerland been known for at least since the beginning of 19th century - strong federalism and an unusually wide use of direct democracy (in particular on the cantonal level). As Pavel Molek says, the example of the Helvetic constitution was not exactly encouraging for the fate of "eternity clauses“ in European constitutions (Molek, 2014, 35).

The oldest existing eternity clause is to be found in the 1814 Norwegian Constitution, which is the second oldest existing constitution in the world. The Norwegian eternity clause outlaws any changes to the basic spirit and principles of the Constitution (Article 112). As Eivind Smith writes, the Norwegian „eternity clause“ has ensured the smooth constitutional development of the Kingdom of Norway, but it has failed to ensure the survival of some of its original founding principles, which were deeply monarchist (Smith, 2011). That means that despite its declared objective having failed, another, just as noble, goal has been achieved. It is somewhat ironic, but herein perhaps lies the true power of "unamendable clauses". 
Many more examples of eternity clauses can be found around the world, some of them rather peculiar. The 1924 Mexican Constitution established that the only religion of the Mexican nation is and forever will be Apostolic Roman Catholicism. Quatar's 2004 constitution enacts the inviolable position of the emir. Several constitutions adopted in Niger enacted „eternal“ amnesties for perpetrators of certain crimes against humanity. The Constitution of the Fifth Republic of Niger from 8 July 1999 stated in Article 134 that no changes to the last article of the Constitution, i.e., Article 141, are permissible. Said Article stipulates: Amnesty is given to perpetrators of attempted coups d'état from 27 January 1996 and 9 April 1999. (Roznai, 2017).

Modern eternity clauses are however inspired mostly by a French constitutional amendment of 1884, which laid down the republican system of government as an eternal principle of the state, and in particular by German Basic Law, whose Article 79(3) prohibits any changes concerning the division of the federation into states, participation of the federal states in the legislative procedure or principles enumerated in Articles 1 and 20 of the Basic Law (republican form of government, principles of democratic, federative and welfare state, sovereignty of the people, separation of powers, constitutionality of the legislative process and legality of the executive and judicial powers). It is a frequently voiced opinion that the Basic Law was drafted with memory of the failure of the Weimar Republic (Lapčáková, 2009). Many famous decisions of the Indian Supreme Court and the entire Indian approach to this issue have been inspired by the German legal environment (Roznai, 2013).

What does then constitute the difference between the material core of a constitution and its unamendable provisions? Let Pavel Molek's metaphor help us understand: „...should we compare the constitution to a medieval castle, then the material core is the centre of the castle, the main tower, without which the rest of the castle will have no purpose and become a mere walled cluster of random buildings; on the other hand, the unamendable elements may be compared to fortification walls which we usually build at the place where the last attack came from. ...In contrast to the unamendable elements, the material core of a constitution does not need to aspire to eternity, quite the opposite. It may be fluid and its meaning may shift just as a people's perception of the defining features of a given constitution does." (Molek, 2014).

An eternity clause is therefore a practical instrument rather than the essence of a constitutional system. It plays a similar role to other tools protecting the rigidity of the constitution, such as a qualified majority, confirmatory referendums etc.

It is therefore up to us, or rather up to the constituent legislator, to decide which principles deserve stronger protection. It is mere coincidence, that in the Czech Republic such protection is designed very broadly and generally as it tries to "fortify“ all the essential elements of the democratic rule of law.

That brings us to the heart of the problem, which is a definition of what the Constitutional Court perceives as Czech constitutional identity - i.e., the concept of the essential elements of a democratic state governed by the rule of law.

\section{Essential elements of a democratic state governed by the rule of law}

The essential elements of a democratic state governed by the rule of law cannot be equated to unamendable constitutional provisions or the material core of the Czech Constitution, and, despite what the Constitutional Court asserts, not even to the constitutional identity of 
the Czech Republic. Constitutional Court Justice Kateřina Šimáčková uses the term explicitly in her dissenting opinion. She argues that the Czech constitutional identity also includes two specific constitutional provisions based on Czech historical experience which includes closed borders and shooting at refugees trying to cross the borders during the communist regime (Resolution of the Constitutional Court No. Pl. ÚS 13/20 from 5 May 2020).

The notion of essential elements of a democratic state governed by the rule of law is rather fluid and general defined by an ever-evolving set of characteristics.

The notion therefore differs from the other concepts explained above. In Czech discourse, it is however often incorrectly used interchangeably with both the material core of the Constitution and its unamendable elements.

Pavel Holländer defines the term very broadly when he sees the material essence of the system not in the Constitution or any parts thereof, but in values and principles which are in principal independent of the Constitution (Sládeček and Mikule and Syllová, 2007). A commentary written by the "fathers of the constitution“ Dušan Hendrych and Cyril Svoboda defines the essential elements of the rule of law more narrowly as the principles encompassed in Article 1(1), Article 5 and Article 6 of the Constitution (Hendrych and Svoboda, 1997). Václav Pavlíček and Jiří Hřebejk's commentary goes only slightly further and adds reference to the sovereignty of the people embodied in Article 2(1) of the Constitution (Pavlíček and Hřebejk, 1998). Other authors naturally attempt to define the essential elements of a Czech democratic state governed by the rule of law (Šimíček, 2009), (Wintr, 2006).

A number of constitutional lawyers have tried to define the democratic rule of law (or its essential elements) more precisely. These efforts have culminated in the monograph authored by Maxim Tomoszek, which deals not only with the essential elements of a democratic state governed by the rule of law, but also with the notion and the principles of the democratic rule of law as such (Tomoszek, 2016).

According to Tomoszek, the essential elements of the democratic rule of law are a subset of elements which define the concept of the democratic rule of law as such (Tomoszek, 2016). His understanding of the essential elements of the rule of law is value based rather than formal, which means that respect for the principles of democratic decision-making and for the formal aspects of the rule of law is not sufficient. It is also necessary to honour the material essence of the rule of law. Further, the ultimate definition of the democratic rule of law must encompass all of the following principles: legal certainty, separation of powers, protection of basic human rights and democracy (Tomoszek, 2016).

Attempts to closely define the essential elements of a democratic state governed by the rule of law are not limited to legal theory. The Constitutional Court has, quite understandably, repeatedly refused to provide an exhaustive catalogue or list of elements which it considers essential for the preservation of the democratic rule of law. Nonetheless, several of its past decisions offer certain clues. Decisions no. Pl. ÚS 19/93, III. ÚS 31/97, Pl. ÚS 36/01 and Pl.ÚS 19/08 revealed that the Constitutional Court understands the essential elements of the democratic rule of law materially rather than formally and that it gives utmost priority to specific legal principles, rights and democratic values. It appears that for the Constitutional Court, the guiding constitutional principle, i.e., the „essential element" is the priority of individual rights, such as the fundamental human and civil rights embodied in the natural 
law sections of the Charter of Fundamental Rights and Freedoms. Case law produced by the German Constitutional Court perceives human dignity as the highest value of the Basic Law (explicitly in a judgment of the Constitutional Court of the Federal Republic of Germany from 10 May 1957, no. BVerfGE 6 (1957)).

Already in Pl. ÚS 19/93 from 21 December 1993 which addressed Act No. 198/1993 Sb., on Illegality of the Communist Regime and on Resistance Against It, the Constitutional Court asserted that „... our new constitution is not based on value neutrality..., but encompasses regulative ideas which protect the basic untouchable values of democratic society..., it does not require only the formal legality of positive law, but ties the interpretation and application of legal rules to their material essence, i.e., requires that the law respects the basic constitutive values of democratic society and at all times measures the application of legal rules against these values. This means that even though there might be a formal continuity with the ,old law', there is a value discontinuity with the ,old regime."

In its decision no. I.ÚS 517/10 from 15 November 2010 on mandatory disclosure of membership of judges in the Czechoslovak Communist Party, the Constitutional Court repeated that major political and economic changes occurred in Czechoslovakia after the Velvet Revolution. As a result, a new system of values based on modern democracy has been introduced, through whose lens it was - and still is - necessary to interpret both existing and former legislation, where still applicable. The Constitutional Court has repeatedly ruled that the purpose and meaning of legislation cannot be sought only in the wording of an individual piece of legislation, but that the basic principles acknowledged by democratic states must always be respected.

This represents a sharp departure from the values and principles asserted by the previous regime. However, that is only a general proclamation and negation of the past. What are the specific positive material values honoured by the new regime?

In its decision no. I.ÚS 420/09 from 3 June 2009 on constitutional requirements for the publication of international treaties, the Constitutional Court ruled that since „..the main purpose of the state and state power is without doubt to ensure respect for the rights and freedoms of the individual, the concept of the democratic rule of law must be construed accordingly." This decision refers to an older decision of the Constitutional Court no. Pl. ÚS 43/93 from 12 April 1994 on the criminal offence of defamation of Parliament, Government and the Constitutional Court (interpretation of the legal terms of presidential decision and countersignature) and quotes the following section: "Principles of the democratic rule of law are based on the priority of the citizen before the state, and thereby on the priority of basic human and civil rights and freedoms".

It seems that, according to the Constitutional Court, the leading principle of Czech constitutionalism is the priority of the individual rights of natural persons and the protection of fundamental human rights embodied in the natural law provisions of the Charter of Fundamental Rights and Freedoms. However, this does not exhaust the concept of essential elements of the Constitution.

Other specific principles and constitutional provisions which reflect the essential elements of the democratic rule of law can be systematically divided into political rights, or democratic principles, and two rather broad cross-cutting areas, which are naturally the main focus of 
the Constitutional Court, i.e., the legislative process and application of law in general.

The legislative process overlaps with all the other categories. According to the Constitutional Court, the fundamental principles of the rule of law include the principle of predictability of the law, its clarity and non-contradictory nature. For example, in judgment no. Pl. ÚS 77/06 of the Constitutional Court from 15 February 2007 on legislative riders and their constitutionality.

The famous „Melčák“ decision (no. Pl.ÚS 27/09 from 10 September 2009), in which the Constitutional Court stood up to the constituent legislator itself, when it appealed to the Czech eternity clause and abolished a special constitutional law which prematurely ended the term of the then-current Chamber of Deputies, made a rather clear, albeit controversial, conclusion, that the essential elements of the democratic rule of law also include the law's general character and a ban on genuine retroactivity. This decision provoked strong reactions not only among legal theorists. A deeper reflection is beyond the scope of this article as it infers a pool of other constitutional questions.

Should we need a summary of the essential elements of the democratic rule of law, the best place to look would be the Constitutional Court's first "Lisbon judgement" (no. Pl.ÚS 19/08 from 26 November 2008), which says that „...Already in the preambles to the Charter of Fundamental Rights and Freedoms and the Constitution did the constituent legislator express an unconditional commitment to the values which stand as the fundaments of our constitutionalism; it, among other things, acknowledged the inviolability of the natural rights of individuals based on the universally shared values of humanity and expressed a determination to protect and develop the Czech Republic in the spirit of the inviolable values of human dignity and freedom, and the will to stand alongside states which honour these values as a member of the family of European and global democracies. With respect to the wording used in the Constitution and the Charter of Fundamental Rights and Freedoms, Article 1(1) of the Constitution and Article 1 of the Charter of Fundamental Rights and Freedoms are essential as they proclaim that the Czech Republic is a sovereign democratic state governed by the rule of law based on respect to inviolable and indefeasible rights and freedoms of people, free and equal in their rights and dignity. The rights and freedoms of minorities in general and from a national and ethnic perspective are provided for in Article 6 of the Constitution (which renders their protection mandatory) and in the third Chapter of the Charter of Fundamental Rights and Freedoms. The ban on discrimination is provided for in particular in the section on the economic and social rights of the Charter of Fundamental Rights and Freedoms; the political system itself is, according to Article 5 of the Constitution, based on free competition of political parties which reject violence as means of advancing their interests and which respect fundamental democratic principles."

In the famous case of "Slovak pensions" (sometimes also referred to as „Holubec"), the Constitutional Court upheld a complaint made by former train driver Karel Holubec despite the opposite opinion of the CJEU, which the Constitutional Court proclaimed to be „ultra vires". The Constitutional Court thus placed the material core of the Czech Constitution and the protection of individual rights beyond the international obligations of the Czech Republic (Judgment of the Constitutional Court No. Pl. ÚS 5/12). The irony of the case is that the claimant achieved no real satisfaction since his pension after the end of the dispute had 
already reached the demanded amount and he was therefore not entitled to any additional compensation. The dispute was therefore purely formal.

It is therefore clear that by including social rights, the Czech Constitutional Court understands the essential elements of a democratic state governed by the rule of law rather broadly. At the same time, it is possible to trace a clear pattern in the understanding of the term in the practice of the first two Constitutional Courts, which can be manifested in two postulates. The first is the priority given to the protection of individuals and their "natural“ rights. The second is the rule of law, which even the parliamentary majority must obey.

Nevertheless, such inspiration drawn from the "activist" German Constitutional Court is "drying up", which candidates for the European Parliament for the Pirate Party and the Green Party learnt the hard way when the Constitutional Court failed to defend them, contrary to its German counterpart, and did not abolish the electoral threshold (Judgment of the Constitutional Court No. Pl. 14/14).

It appears that particularly "Milos Zeman's Constitutional Court," now fully appointed by the re-elected President, will not be willing to continue in the direction set by the "Melčák" case. However, the Constitutional Court is still prepared to defend the values of liberal democracy, albeit not in such a spectacular manner.

Most importantly, the Constitutional Court continues to create the impression that the essential elements of the democratic rule of law are identical to the material core of the Constitution, its unamendable provisions and thereby the constitutional identity itself.

It is therefore necessary to reiterate that it is not a generally shared opinion that the essential elements of the democratic rule of law are identical to the eternity clauses enacted in constitutional legislation. Some constitutions identify as „unamendable“ a form of government (such as the republican system of government in France or Turkey), the state's territory (Ukraine) or certain specific values protected by the constitution (Germany or Romania).

Moreover, the Czech constitution works with one more as yet unclassified category, namely the "fundaments of a democratic state" referred to in Article 9(3) of the Constitution. Differences between "essential elements of a democratic state governed by the rule of law" and "fundaments of a democratic state", if any, are yet to have a significant impact on legal theory and practice. As Pavel Molek says, the idea of „rational legislator“ implies that identical concepts should not be referred to by different terms. Molek therefore does see a difference between these two concepts. In his opinion, Article 9(2) defines the unamendable elements of the Constitution, while the objective of Article 9(3) is to protect its material core (Molek, 2014).

Maxim Tomoszek asks whether the distinction is caused by mere omission or a lack of attention paid to the drafting process of the Constitution and concludes that the distinction is likely intentional and symbolizes a relationship between the principles of democracy and the rule of law (Tomoszek, 2016).

An intentional use of two different terms might also be a nod to the future interpreters of the Constitution (in particular to the Constitutional Court) reminding them to pay heed to the democratic character of the state. Whether this has any practical impact is not entirely clear and there is actually more ambiguity than clarity about the matter. 


\section{CONCLUSION}

This article aspires to shed more light on the understanding of the notions of the constitutional identity, the material core of a constitution and unamendable elements of a constitution (eternity clauses) and on the concept of essential elements of a democratic state governed by the rule of law as reflected in the practice of the Czech Constitutional Court.

The material core or the focal point of the constitution is one of the defining features of the constitutional system. Just as sparkling wine without bubbles would still be „wine“ but no longer "sparkling“, a concrete constitution without its core would remain a constitution, but of an entirely different kind.

This however does not mean that these „bubbles“ are necessarily identical to the essential elements of a democratic state governed by the rule of law. There are many kinds of wine and therefore, a democratic state governed by the rule of law may also have quite different character, such as a republic or a monarchy.

Application of the above concepts has very specific effects on the law-making process, decisions of the Constitutional Court, and legal practice in general. It is therefore necessary to define and make a clear distinction between them, even though they may overlap in specific cases.

Although it is desirable to "draw a clear line“ between the concepts of the essential elements of the democratic rule of law and the material core of the Constitution, we may conclude that from a legal point of view, the Constitutional Court subjects all these terms to the same standard, namely the priority of the individual and the protection of the fundamental rights of man and citizen as embodied in the natural law provisions of the Charter of Fundamental Rights and Freedoms. It is through this prism that the constitutional identity of the Czech Republic should be seen.

The Czech Constitutional Court actually goes as far as to equate the Czech constitutional identity with the above concepts, i.e., with material principles of the rule of law, despite the conceptual inconsistency and contradiction embedded in such an approach.

As mentioned in the introduction, despite its limitations, there are certain positive effects to such a view. An express commitment to the protection of the rights of the individual may not correspond to the „popular“ perception of the Czech constitutional identity, it may however serve as a useful argument in specific legal cases.

\section{REFERENCES}

Besselink, L. F. M. (2010). National and Constitutional Identity before and after Lisbon. Utrecht Law Review, vol. 6, no. 3 .

Bogdandy, A. von - Sschill, S. (2011). Overcoming Absolute Supremacy: Respect for National Identity under the Lisbon Treaty. Common Market Law Review, vol. 40, no. 5.

Fabbrini, F. Sajó, A. (2019). The Dangers of Constitutional Identity. European Law Journal, vol. 25, no. 4, 457-473. DOI 10.1111/eulj.12332

Faraguna, P. (2017). Constitutional Identity in the EU. A Shield or a Sword? Germal Law Journal. vol. 18, no. 7, DOI:10.1017/S207183220002246X 
Grinc, J., Ondřejková, J. (2016). Stát a nadnárodní integrace. Případ Evropské unie. [State and International Integration. Example of the European Union.] In: Kysela, J. - Ondřejek, P. Kolos na hliněných nohou? K proměnám státu a jeho rolí. [State as a Giant with Feet of Clay]. Praha. Leges.

Hašek, J. (1974). The Good Soldier Švejk and his Fortunes in the World War. London. Penguin Books.

Hendrych, D. and Svoboda, C. (1997). Ústava České republiky: komentář. [Constitution of the Czech Republic: Commentary]. $1^{\text {st }}$ ed. Praha. C. H. Beck.

Holländer, P. (2005). Materiální ohnisko ústavy a diskrece ústavodárce. [Material Core of the Constitution and Discretion of the Constituent Legislator]. Právník, vol. 144, no. 4.

Jacobsohn, G. J. (2010). Constitutional Identity. Cambridge, Massachusetts. Harvard University Press.

Kosař, D. Vyhnánek. L. (2018) Ústavní identita České republiky [Constitutional Identity of the Czech Republic], Právník, vol. 157, no. 10, 855.

Lapčáková, M. (2009). Materiálne jadro základného zákona Spolkovej republiky Nemecko z pohladu Spolkového ústavného súdu. [Maerial Core of the Basic Law of the Federal Republic of Germany in the View of the Federal Constitutional Court]. IN Ondrej Hamulák (ed.). Fenomén judikatury v právu. [The Phenomenon of Case Law]. Olomouc. Leges

Mangoldt, H. von. (2002). L'identité des Etats membres de l'Union européenne. In: Vitzthum, W. Peňa, M. (eds). L'identité de l'Europe. W. Marseille. PUAM.

Molek, P. (2014). Materiální ohnisko ústavy: věčný limit evropské integrace? [Material Core of the Constitution: An Eternal Obstacle to EU Integration?]. 1st ed. Brno. Masaryk University.

Pavlíček, V. and Hřebejk, J. (1998). Ústava a ústavní řád České republiky: komentář. [Constitution and Constitutional System of the Czech Republic: Commentary]. $2^{\text {nd }}$ exp. ed. Praha. Linde.

Ponthoreau, M.C. (2018). Interpretations of the National Identity Clause. In: Baroncelli, Stefano et al. Back to Maastricht: Obstacles to Constitutional reform within the EU Treaty (1991-2007). Newcastle. Cambridge Scholars Publishing.

Roznai, Y. (2013). Unconstitutional Constitutional Amendments - The Migration and Success of a Constitutional Idea. American Journal of Comparative Law, vol. 61.

Roznai, Y. (2017). Unconstitutional Constitutional Amendments - The Limits of Amendment Powers, $1^{\text {st }}$ ed., Oxford.

Sajó, A. (2019). On Constitutional Identity and the Loyalties of the Constitutional Judge. Cardozo Law Review, vol. 40, no. 6, 3253-3276.

Sládeček , V., Mikule, V. and Syllová, J. (2007). Ústava České republiky: komentář. [Constitution of the Czech Republic: Commentary]. $1^{\text {st }}$ ed. Praha. C.H. Beck

Smith, E. (2011). Old and Protected? On the „Supra-constitutional“ Clause in the Constitution of Norway. Israel Law Review. vol. 44, $3^{\text {rd }}$ ed.

Šimíček, V. (2009). Materiální ohnisko ústavního pořádku, jeho ochrana a nález Ústavního soudu ve věci M. Melčáka. [Material Core of the Constitutional System and its Protection and the Melcak Judgment of the Constitutional Court]. In Vladimír Klokočka - liber amicorum. $1^{\text {st }}$ ed. Praha. Linde,

Tomoszek, M. (2016). Podstatné náležitosti demokratického právního státu. [Essential Elements of a Democratic State Governed by the Rule of Law]. $1^{\text {st }}$ ed., Praha. Leges,

Wintr, J. (2006). Principy českého ústavního práva s dodatkem principů práva evropského a mezinárodního. [Principles of Czech Constitutional Law with Reflections on Principles of European and International Law]. $1^{\text {st }}$ ed. Praha. Eurolex Bohemia,

Zbíral, R. (2014). Koncept národní identity jako nový prvek ve vztahu vnitrostátního a unijního práva: poznatky z teorie a praxe. [The Concept of National Identity as a New Element in the Relationship between National and EU Law: Lessons from Theory and Practice]. Právník, vol. 153, no. 2, 133. 


\title{
VECTORS OF DEVELOPMENT OF EDUCATIONAL AND METHODOLOGICAL COMPETENCE OF THE MODERN TEACHER IN THE CONDITIONS OF MODERNIZATION OF VOCATIONAL EDUCATION OF UKRAINE
}

\author{
Svitlana Shevchuk, \\ SIHE “University of Education Management" \\ NAPS of Ukraine, Senior Lecturer, \\ Professional Education Methods, \\ Social and Humanitarian Disciplines Department Bila Tserkva \\ Institute of Continuous Professional Education, \\ Bila Tserkva, Kyiv region, Ukraine \\ https://orcid.org/0000-0001-6260-3323 \\ shevchukbinpo@ukr.net \\ Volodymyr Kulishov, \\ SIHE "University of Education Management" \\ NAPS of Ukraine, Associate Professor, \\ Professional Education Methods, \\ Social and Humanitarian Disciplines Department Bila Tserkva \\ Institute of Continuous Professional Education \\ Candidate of Pedagogical Sciences, \\ Bila Tserkva, Kyiv region, Ukraine \\ https://orcid.org/0000-0003-3262-796X \\ kulishov_04@ukr.net \\ Tetiana Shchypska, \\ SIHE "University of Education Management" \\ NAPS of Ukraine, Senior Lecturer, \\ Professional Education Methods, \\ Social and Humanitarian Disciplines Department Bila Tserkva \\ Institute of Continuous Professional Education \\ Bila Tserkva, Kyiv region, Ukraine \\ https://orcid.org/0000-0003-1649-3789 \\ shchypska@ukr.net
}

\begin{abstract}
The modern model of socio-economic development of Ukraine must meet an effective system of vocational and professional higher education, which can quickly adapt to market demands and provide training for skilled workers who are able to be competitive in the existing socio-economic space.. In recent years, a change in the educational paradigm is taking place in the state: from information-cognitive, inherent in industrial society, to personal-activity, based on a competency-based approach to the educational process, characteristic of the post-industrial, information society. Educational practice objectively needs to make a particular student the main figure in the educational process, thus focusing
\end{abstract}


the activities of teachers of vocational education on the personification of the process of professional training. Significant changes in society, social life, the productive sector of the economy and the sphere of state services necessitate the training of a pedagogical worker with a fundamentally new type of thinking. An employee who is ready to carry out innovative pedagogical and scientific-methodical activities, professionally competent, who is able to perform constructive actions in various situations of a professional nature and carry out educational and methodological activities at a high scientific level in accordance with modern educational requirements.

The article presents the main approaches to the development of professional competence of a teacher of the system of vocational and professional higher education. One of the leading components of professional development of a teacher is his ability to modern educational and methodological activities, which involves designing classes based on a competency approach, the use of innovative educational technologies, the introduction of integrated learning in the system of vocational education.

Keywords: integration in education, competence approach in education, educational technology, professional competence, educational and methodical competence, technological approach in education.

\section{INTRODUCTION}

Education, as one of the most important components of society, on the one hand, depends on the processes taking place in it, and therefore must respond quickly and meet the state of scientific and technological progress, trends in the economic sphere of the country. On the other hand, education certainly affects all processes and aspects of society, as it prepares professionals for various fields, develops the personality of students, and forms their certain social and life views. In this context, special attention is paid to the development of methodological competence of pedagogical workers of vocational education, their readiness for continuous professional development. As stated in the Concept of implementation of state policy in the field of vocational education "Modern vocational education" for the period up to 2027, one of the problems is the inconsistency of educational content and teaching methods to modern labor market and individual needs (Concept, 2019). The current state, prospects and problems of innovation in education in our country, the willingness of the teaching community to accept and implement them in their professional activities is an important point in the implementation of the tasks of reforming vocational education.

Modern education today is forced to be on the crest of innovative change, and at the same time remains a traditional institution of socialization, sanctioned by the state and designed to fulfill the public order. However, when the social order for vocational education and the content of this education change, it is difficult for teachers of vocational schools. They, for the most part, are accustomed to using traditional forms and methods of educational, organizational, and scientific-methodical activity in their practice, to lead their pedagogical activity in accordance with educational innovations. Modern education today is forced to be on the crest of innovative change, and at the same time remains a traditional institution 
of socialization, sanctioned by the state and designed to fulfill the public order. However, when the social order for vocational education and the content of this education change, it is difficult for teachers of vocational schools, who, for the most part, are accustomed to using traditional forms and methods of educational, organizational, and scientific-methodical activity in their practice, to lead their pedagogical activity in accordance with educational innovations.

The purpose of the article is to highlight the essence of educational and methodological competence of a modern teacher and vectors of its development in the planning, organization and implementation of the educational process in institutions of vocational and professional pre-higher education.

\section{THEORETICAL FOUNDATIONS}

The problem of development of educational and methodical component of professional competence of pedagogical workers of the system of professional-technical and professional higher education is in the center of attention of researchers. Because this component of the activity of a modern teacher plays a leading role in the process of modernization of national education.

V. Vvedensky, M. Zhaldak, I. Zyazyun, N. Nychkalo, M. Kornilova, O. Lokshina, L. Vashchenko, O. Ovcharuk, O. Pometun, O. Savchenko, S. Sysoeva O. Semenog, E. Azimov, N. Bibik, L. Karpova, M. Kademiya, A. Kolomiets and others systematically researched the development of professional competence of a teacher.

A number of modern scientists-educators (V. Sidorenko, V. Kovalchuk, L. Orshansky, A. Vitchenko, I. Clark, L. Liktey, V. Adolf, N. Tarasenkova, O. Nikolaev, S. Skvortsova, I. Malova, I. Zaichenko, I. Akulenko, O. Lebedeva, O. Zubkov, T. Gushchyna, T. Rudenko, L. Mitina, L. Sherstyuk, J. Gayevets, J. Tsymbalyuk, etc.) distinguish methodological competence as one of the main components of professional development of teachers.

Publications by S. Bolsun, R. Gurevych, L. Danylenko, N. Nychkalo, V. Oliynyk, L. Petrenko, V. Radkevych, L. Sergeeva, N. Chypylenko, L. Shevchuk and others are devoted to the problem of development of creative potential of a modern professional teacher. Education, creating a positive image and readiness to implement innovative educational and methodological activities

\section{RESULTS AND DISCUSSION}

Competence approach, which is becoming important, is recognized as one of the priority areas of modernization of education in Ukraine. Because it shifts, the emphasis from the process of accumulation of normatively defined knowledge, skills and abilities in the plane of formation and development of students' ability to act practically and creatively apply the acquired knowledge and experience in different situations. In view of this, the urgent tasks that need to be addressed urgently are the replacement of the educational paradigm from a system focused on the teacher as a "knowledge repeater" to a system focused on the learner, according to which the teacher acts as an organizer of educational activities. Student behavior (student, listener) varies from passive learning to research-active, 
independent and self-educational activities. Therefore, the competence approach can be considered an alternative to the educational process, built on the basis of the didactic triad "knowledge - skills - skills", in which there was a problem of separation of knowledge from the ability to apply them. The introduction of a competency approach to the vocational education system is accompanied by improved interaction with the labor market, increased competitiveness of professionals, updating the content, methodology and appropriate educational environment.

Competence approach is the focus of the educational process on achieving integrated learning outcomes, which are general (basic, key) and special (subject) competencies of students. General (basic, key) competencies ensure the continuity and consistency of learning throughout a person's life. They are gradually deepened and enriched depending on the level of education. In the system of vocational and professional pre-higher education there are general (basic, key), and professional (related to specialty and specialization) competencies (Vitchenko, 2019).

In pedagogy, the competency approach is defined as "a set of interrelated concepts, ideas and methods of pedagogical activity", "methodological tools for solving complex problems", conceptual, mutually agreed views on the target guidelines of teaching and education, ways and means of their implementation under certain conditions. Educational policy, educational environment, etc.). Therefore, the competence approach in vocational education should be understood as a unity of the following leading provisions:

- focus on achieving integrated training indicators for future professionals;

- systematic acquisition of the main groups of competencies - general (key), professional and professional;

- dependence of the system of competencies on the level and degree of professional education, its gradual complication, renewal and enrichment;

- focus on socialization and professionalization of the individual, the constant deepening (improvement) of competencies in continuing education.

The fundamental difference between the competence educational paradigm is the target orientation of professional education, the values of the subjects of study, the expected results of educational and professional training of future professionals. In accordance with the realities and needs of the information society, the competence-oriented vocational school abandons the outdated practice of transferring and reproducing ready-made knowledge, directs all participants in the educational process to achieve integrated indicators in personal and professional development, which means competencies (Clark, 2015).

Competence approach in education is aimed at the formation of competencies as manifestations of awareness of the teacher in certain issues, skills of practical application of knowledge, values to themselves, others and the environment.

Competence is a modern dimension of human education, when the first place is given not to the amount of material studied, but to the result, embodied in the ability to act in different conditions and circumstances.

A teacher who applies a competency-based approach does not act as a "repeater" of educational material. He acts as a mentor, organizer of educational activities with many opportunities. 
The role of the learner is transformed from passive perception and reproduction of knowledge into research and self-educational activities. He realizes that the key to success is the desire for self-development and positive motivation.

The term "competence" has also become widely used in defining such an integrated quality of a teacher as professionalism. In the International Quality Standard, adopted in Ukraine as a state (State Standard of Ukraine ISO 2000-2001), competence is defined as "the availability of appropriate education, training, qualifications and experience." The Standard of Higher Education of Ukraine defines competence as "knowledge and experience in a particular activity". Professional and pedagogical competence is seen as "the ability of teachers to" transform the learning process into a means of shaping the personality of students "and reflects the ability of a vocational school teacher to quickly, independently and effectively solve current pedagogical problems. Competence is a universal combination of skills, knowledge, abilities, and ways of thinking, valuesand ideological beliefs, which allow you to confidently and successfully get out of various life situations.

In accordance with the basic concepts and definitions of the updated National Qualifications Framework adopted by the Government of Ukraine (Resolution № 519 of 25.06.2020), the integral competence of a specialist is defined as a generalized description of the qualification level that expresses the main competence characteristics of the level for training and / or professional activity.

Its main indicators determine the professional competence of a teacher: readiness for educational and scientific-methodical activities, personal pedagogical skills, innovative thinking, and professional prognostic skills. The professional competence of a teacher consists of scientific-professional, methodological, socio-psychological, differentialpsychological, reflexive, superdisciplinary (key ",' basic) competencies.

The essence of educational and methodical activity is to master the knowledge available in science, the formation of skills, abilities and concepts, the study of the practice of teaching experienced colleagues and recognized in the world pedagogical science professionals.

Educational and methodical competence is a system of methodical knowledge, skills, abilities, competencies of a teacher, connected with the methods of teaching a specific academic discipline; sufficient level of mastery of specific techniques, methods, techniques and means of pedagogical activity, which depends on the inclusion of students in various types of cognitive activities and the development of the study group (Tolochko, 2019).

Educational and methodological competence is one of those competencies that are recommended by European conventions, as it provides for independence and responsibility. The stage of professional methodological development of pedagogical workers of vocational education institutions presupposes their ability to choose technologies and methods of conducting educational activities on the basis of their own experience. At the same time, modern methodology dictates pedagogical conditions, where the teacher acts as a facilitator (consultant), who is able to solve professional problems regulated by his own activities. At the same time, when choosing methods autonomously, it is important to keep in mind the professional requirements for teaching professional disciplines (Liktey, 2020).

The teacher's focus on creating his own methods, willingness to optimize methodological projects, experimental research, modern educational technologies and methods of teaching 
general and special disciplines, obtaining new results in educational, organizational, and methodological activities is based on the development of his teaching and methodological competence.

Any educational concept, including the concept of a competency-based approach to vocational training, is implemented through a complete system of actions. If this system is quite variable and flexible, it is called a teaching method. If there is a more or less clear algorithm and the final result is guaranteed with a reliably estimated probability, this educational system is called learning technology. In other words, the technological approach to learning is the introduction of a systematic way of thinking in pedagogy. This approach to educational and pedagogical processes allows: to provide accurate instrumental, methodological, communicative management of the educational process; significantly increase the probability of achieving the predicted result; scientifically substantiated to analyze and systematize the existing practical experience and its use; make optimal use of the real situation on available resources, reduce the impact of adverse circumstances on the participants of the educational process and create conditions for personal development; choose the most effective and develop new advanced technologies of training and production process to solve problems.

According to UNESCO, educational technology is, in general, a systematic method of creating, applying and defining the whole process of teaching and learning, which takes into account human and technical resources, their interaction and aims to optimize forms of education.

Optimization of the educational process is understood as the choice of such a technique, the application of which will lead to the best results with the minimum necessary time and effort. Optimization involves the most effective (optimal) course of the pedagogical process in terms of given criteria based on a comprehensive account of patterns, principles, modern forms and methods of teaching and education, existing conditions and characteristics of teachers and students (Kaplunovsky, 2005).

Educational technology can be considered as a pre-designed learning process with clearly defined functions of teachers and students at each stage of this process, which with a high level of probability leads to the achievement of a guaranteed result. The algorithm for managing this process can be a kind of scenario (project), which reflects the implementation of the content of technology through the use of a system of techniques, methods, forms of organization and learning tools to achieve the planned goals.

The technological approach in education contributes to the introduction of a systematic approach and covers a wide range of theoretical and practical issues of management, organization of the educational process, the introduction of innovative forms, methods, tools and technologies of teaching. This approach frees the teacher from arbitrariness in planning the learning process and allows you to purposefully achieve the predicted end result, provided a clear justification of each stage and components of the learning process. The technological approach in teaching the profession allows to comprehensively solve educational and upbringing goals, choose the most effective technologies and models of teaching to solve emerging pedagogical and methodological problems, analyze and systematize on a scientific basis the existing pedagogical experience of optimizing the educational process. 
Implementation of competence and technological approaches in education are the main vectors of development of educational and methodological competence of a modern teacher of a vocational school.

Competence lesson is a lesson of personality-oriented, activity, creative. Designing a competency lesson is a transformation of its content component into a means of achieving the main didactic goal and planned results.

The competency approach to such a lesson is focused on the organization of educational and cognitive activities of students by using of interactive educational technologies in the educational process. With this approach, preference is given to creative pursuits, the main task of which is to organize productive active activities of students.

The main characteristics of the competency lesson are (Pometun, 2018):

- lack of a strict algorithm for conducting classes, assuming situationality in its didactic structure;

- providing students with the opportunity to choose the path and trajectory of learning new knowledge, skills and abilities;

- effective use of interactive, exploratory and research teaching methods;

- the possibility of diversifying approaches and points of view to the coverage of educational material and its competent interpretation;

- use of reflection, self-presentation and protection of students' creative product instead of external control.

The specificity of the competency lesson is that students do not learn "ready knowledge" offered by the teacher, and trace the conditions of origin of this knowledge. It is implied that the pupil (student) forms the concepts necessary to solve a particular problem himself. In this approach, the educational activities of the learner, who periodically assumes the role of researcher or practice-converter, itself becomes the subject of assimilation. In such training, the student learns new types of experience: identifies and identifies problems, acquires research and design skills, cooperation, applies known and creates new technologies for acquiring knowledge.

The organization of a competence lesson focused on the result begins with a clear awareness of the teacher of the desired level of academic achievement of students. The teacher should strive to formulate clear, understandable, real, measurable results as a separate lesson, and the study of a topic, section or course. Therefore, instead of a vague goal setting at the initial stage of the teacher's lesson, it is necessary to determine the expected learning outcomes, which is a mandatory and important procedure, because without it, the effective application of a particular model of learning (forms, methods, technologies, tools, etc.). In addition, the expected learning outcome is always the level of educational knowledge and skills achieved by students, for the formation and development of which such conditions were created during the lesson. Reflection acts as a method of finding out how and how other participants in the educational process understand the teacher, his personal qualities, emotional reactions, professional abilities and capabilities.

Reflection is understood as a specific form of theoretical activity aimed at understanding and analyzing one's own actions. It is very important for the teacher to establish to what 
extent the obtained results (positive or negative) are a means of successful activity of students in the process of mastering the profession.

Reflective skills of students take place in the implementation of their control and evaluation activities aimed at themselves, and involve the use of such varieties as: control based on the correlation of the results with the given samples; control based on the expected results of actions performed only mentally; control based on the analysis of the finished results of the actions actually performed. Reflection is not just knowledge or understanding of the subject of pedagogical activity himself, but also finding out how and how other participants in the educational process know and understand his personal characteristics, emotional reactions and professional abilities and capabilities.

Teacher's ability to design a competency lesson (Shevchuk, 2021):

- analytical (reflection of each stage of the competence lesson, analysis of the results of educational activities of students);

- prognostic (goal setting, design, planning, modeling, etc.);

- psychological (mastering the basic pedagogical and psychological diagnostics);

- organizational (managerial).

Competencelessonininstitutions of professional (vocational) education is also characterized by the fact that it solves the problem of motivation of educational activities of students of vocational education. In such a lesson, a model of "learning with enthusiasm" is created. This is, first of all, a lesson in which the teacher skillfully uses all pedagogical opportunities for the development of the student's personality, his active intellectual growth, deep and meaningful acquisition of knowledge in order to form a competent personality. The didactic structure of the lesson is formed in accordance with the type of lesson. The methodical substructure of the lesson, which depends on the methods of its conduct, in contrast to the didactic is a variable and is characterized by greater variability, reflects the main stages of learning and the active nature of the educational activities of students in the classroom.

Based on the above, the competency lesson may contain certain dynamic fields that the teacher can effectively saturate according to their level of professional competence: content, motivation, field of goal setting, technological, reflective, and emotional.

Competencelesson is, firstofall, an interactivelesson. Interactivityis an enhanced pedagogical interaction, the mutual influence of participants in the pedagogical process through the prism of their own individuality, personal life experience. This interaction is characterized by a high degree of intensity of communication of its participants, their communication, exchange of activities, change and diversity of its types, forms and techniques, purposeful reflection by participants of their activities and interactions. The purpose of the interactive process (interaction between the subjects) - change and improvement (improvement) of models of behavior and activities of participants in the learning process.

Therefore, interactive learning is learning in the mode of enhanced pedagogical interaction of participants in the educational process in order to jointly solve educational problems and develop personal qualities of students (Shevchuk, 2021). Interactive learning is based on a new philosophy of constructivism and postmodernism, which becomes the methodological basis of modern educational policy. The main ideas of this philosophy in vocational training are reduced to the need to train responsible, creative, active workers who respect diversity, dialogue of 
cultures, creative interaction. Innovative learning technologies should be based on the active cooperation of teachers and students, their cooperation in the learning process.

Today we can say that in Ukrainian pedagogy a wide range of interactive methods and practices in the classroom are adapted, theoretically sound and involved in the practice of teachers of vocational schools. These are such techniques as situational modeling, interactive training, educational discussions, business and role-playing games, etc. Interactive techniques allow applicants for vocational education:

- thoroughly analyze educational information and creatively approach its assimilation, make the process of assimilation and application more accessible;

- learn to formulate their own opinion, to express it correctly, to prove their point of view, to argue and discuss;

- model and solve cognitive, professional, social and life situations, thus enriching their own cognitive and social experience;

- learn to build constructive relationships in the student group, determine their place in it, avoid conflicts, seek compromises, seek dialogue, find a common solution to the problem;

- to develop skills of project activity, independent work with various sources of information, performance of creative tasks, etc.

The ideas of competence education are inextricably linked to the problems of integration in education. Researchers of these problems argue that integrated learning is fundamentally important for the formation of professional competence of the future skilled worker, and for his future professional activity.

Integration in education is a process (bilateral, systemic and structural) of interpenetration, consolidation, unification of knowledge; establishing the integrity of the content of education; establishing connections between relatively independent things, processes, and phenomena. When these connections are significant, they determine the functioning of the phenomena to be integrated; combining elements that are accompanied by the complication and strengthening of ties between them, the interpenetration of elements of a holistic system, the transition from one form to another; historical movement of knowledge towards unity; interpenetration of information from one training course to another (Rudnytska, Tarnavska, 2018).

The essence of educational integration is to implement the processes of unification of all components of the pedagogical process (content, forms, and methods), which causes: the expansion of educational functions (integrative function); innovative learning (innovative function); modernization of education (integrated technologies); new learning outcomes (comprehensively developed personality).

Integration processes are aimed at the realization of new educational goals - the formation of a holistic system of knowledge and skills of the individual, the development of his creative abilities and potential.

Integrated classes are an interdisciplinary combination of classes aimed at comprehensive knowledge of the topic, laws, and ideas in order to provide students with a deeper understanding of a particular educational or problem situation.

The essence of integrated classes in vocational education institutions is that it is planned, organized and conducted by several teachers (teachers and masters of industrial training). A binary lesson is a type of integrated lesson taught by two teachers. 
The peculiarity of conducting an integrated lesson is in the combination of blocks of knowledge in different subjects, subordinated to one topic of the curriculum. Therefore, it is very important to clearly define the main purpose of the integrated lesson, how this lesson will contribute to the integrity of learning, the formation of students' knowledge at a qualitatively new level.

Integration technology is extremely effective in the training of skilled workers. Meaningful and purposeful integrated classes bring novelty, originality to the traditional structure of vocational education, contribute to the formation of a holistic system of professional knowledge and skills and integrated competence of students, creating favorable conditions for mastering the profession.

Methodologically correct planning, construction and conduct of integrated classes in institutions of vocational and professional higher education contribute to improving the educational and methodological competence of teachers of vocational schools. Because it requires a high level of professionalism, mastery of methods of implementing modern educational practices in the educational process.

The lesson was and remains the main form of professional training, but the extracurricular form of organization of educational and cognitive activities of students in vocational and professional higher education is no less important in their activities, because it allows all subjects of educational activities to expand the scope of interaction for the development of search, research and creative activities. A wide range of didactic and educational goals inherent in the classroom form, are characteristic of extracurricular. These are: implementation of the basic principles of didactics; compliance of the content of education with the current level of scientific achievements in the field; effective and efficient use of innovative educational technologies; ensuring high educational and cognitive activity of students in the process of solving specific and problematic problems of educational, industrial and social nature; rational alternation of different types of activities of students; providing prompt feedback; providing timely operational counseling by teachers and professionals; positive influence on the motivational sphere, stimulation and formation of positive attitude to lifelong learning in students, their independence and creative abilities; development of communicative qualities of students. All the above-described forms, methods and means of activity of the teacher are inherent in the innovative extracurricular educational and organizational work of the teacher of the vocational school. However, the main purpose of such activities is still to focus on the formation of future skilled workers' knowledge, skills and abilities of individualization and differentiation in their search, research and creative activities.

The expansion of the range of educational innovations has led to their penetration into all levels of educational activities, where they are successfully used to increase the efficiency of the educational process. In particular, they are used in extracurricular educational activities, which in vocational (technical) education is one of the main forms of organization of the educational and production process, used in classroom and independent activities of students, is part of the professional competence of teachers, forms and develops methodological competence.

Extracurricular educational activities are closely related to the additional education of future professionals, when it is combined with the development of their creative interests 
and their inclusion in other areas of activity. As you know, additional education of the future specialist is an organic part of the system of education and upbringing, which is focused on the free choice and use of additional educational programs by applicants for educational services. The main purpose of additional education in the process of extracurricular activities is to develop the motivation of subjects of educational activities to cognition and creativity, their personal and professional self-determination, and adaptation to life, society, involvement in a healthy lifestyle (Shevchuk, 2021).

\section{CONCLUSIONS}

One of the main tasks of reforming the system of vocational and professional higher education in Ukraine is the training and development of highly qualified pedagogical staff. Teachers for whom educational and methodological competence is an important aspect of professional and pedagogical development. This approach will solve the problem of inconsistency of teaching methods to the requirements of the modern labor market and the needs of the individual, as stated in the Concept of state policy in the field of vocational education "Modern vocational education" for the period before 2027.

Solving the problem of improving the quality and efficiency of the educational process in the domestic system of vocational and professional higher education is closely related to the above outlined vectors of development of the level of educational and methodological competence of modern teachers in the modernization of vocational and professional higher education in the educational process of institutions of professional education of competence, technological and integration approaches. It is the implementation of these areas will be the key to the deployment of innovative processes in the system of vocational education, which today is a priority area in the socio-economic, spiritual and cultural growth of Ukrainian statehood. It is through changes in the activities of teachers with a focus on educational innovation and its readiness to realize personal creative potential that we can achieve qualitative changes in the educational process of vocational and professional higher education, bring the results of their activities to the standards of the European educational space.

\section{REFERENCES}

Vitchenko, A. O., Vitchenko, A. Yu. (2019) Competence Approach in Modern Higher Education: Educational Innovation or Reformist Simulacrum of the Postmodern Era. Vyshcha Shkola. 4 (177). 52-66.

Kaplunovsky, R. (2005) Optimization of the Pedagogical Process. Education. Technical Schools. Colleges. 1 (11). 14-15.

Clak, I. E. (2015) Theoretical Principles of the Competence Approach in the System of Higher Professional Education. Bulletin of Chernihiv National Pedagogical University. Series: Pedagogical sciences. 124. 32-34.

The Concept of Implementation of state Policy in the Field of Vocational Education "Modern Vocational Education for the Period up to 2027": Order of the Cabinet of Ministers of Ukraine from 12.06.2019 № 419-r. Access mode: https://zakon.rada.gov.ua/laws/show/419-2019-\%D1\%80\#Text

Liktei, L. M. (2020) Current State of Development of Methodological Competence of Teachers of Humanities Disciplines of Pedagogical Colleges. Pedagogy of Formation of Creative Personality in Higher and Secondary School. 68, Vol. 1. 82-85. 
Pometun, O. I. (2018) Competence-Oriented Methods of Teaching History in Primary School: a Manual. Kyiv: LTD «KONVI PRINT», 208 p.

Rudnytska, N., Tarnavska, N. (2018) Didactic Essence of Integration and Ways of Its Realization in the Learning Process. Youth and the Market. 7 (162). 46-51.

Tolochko, S.V. (2019) Concept and Methods of Formation of Scientific and Methodological Competence of Teachers in the System of Postgraduate Pedagogical Education: Monograph. K.: National Pedagogical Dragomanov University, 376 p.

Shevchuk, S. S. (2021) Educational and Methodical Activity of a Teacher of Vocational Education Institutions on the Basis of the Competency Approach: a Textbook. Bila Tserkva: BICPE SIHE «University of Education Management» NAPS of Ukraine, 73 p. 


\title{
PEDAGOGICAL CONDITIONS FOR THE FORMATION OF LEADERSHIP QUALITIES OF FUTURE HEADS OF PRESCHOOL EDUCATION INSTITUTIONS
}

\author{
Yuliya Volynets, \\ Borys Grinchenko Kyiv University, \\ Candidate of Pedagogical Sciences, \\ Senior lecturer of Preschool education department, \\ Preschool Education Department of Pedagogical Institute, \\ Kyiv, Ukraine \\ https://orcid.org/0000-0002-3849-0821 \\ y.volynets@kubg.edu.ua \\ Nadiia Stadnik, \\ Municipal Institution of Kyiv Regional Council \\ «Bila Tserkva professional humanitarian and pedagogical College», \\ Candidate of Pedagogical Sciences, Senior lecturer of the Department of \\ Pedagogy and Psychology of Preschool and Primary Education, \\ Bila Tserkva, Ukraine \\ https://orcid.org/0000-0002-2619-4419 \\ n.stadnik72@ukr.net \\ Tetiana Panchenko, \\ Municipal Institution of Kyiv Regional Council \\ «Bila Tserkva professional humanitarian and pedagogical College», \\ Candidate of Ppsychological Sciences, Senior lecturer of the Department of \\ Pedagogy and Psychology of Preschool and Primary Education, \\ Bila Tserkva, Ukraine \\ https://orcid.org/0000-0002-5010-652X \\ panchtanya@ukr.net
}

\begin{abstract}
The urgency of the studied problem is because in conditions of significant socio-economic changes, the system of human resource management technologies becomes significant, especially relevant is the use of the potential of leadership influence. In this regard, this article is aimed at revealing the problem of developing leadership qualities of heads of preschool education institutions. The article highlights current issues of leadership development of future heads of preschool education. The leading method of the research of this problem is the analysis of the researched problem in pedagogical theory and practice and experimental check of pedagogical conditions of formation of leadership qualities of future heads of preschool educational institutions that allows to reveal and characterize features of formation of leading qualities of future heads of preschool educational institutions. The article identifies the components, criteria, indicators and describes the levels of leadership development of future leaders of preschool education. The basic
\end{abstract}


concepts of the problem are defined: leader, leadership, professional qualities of the leader, leadership qualities of future heads of preschool educational institutions, pedagogical conditions of formation of leadership qualities of future heads of preschool educational institutions. Relevant requirements to the personal and professional qualities of a leader are revealed. The structural components of leadership qualities of future heads of preschool education institutions are characterized, namely: motivational-value, integrative-activity, directional-activity, emotional-reflexive. The pedagogical conditions of the formation of leadership qualities of future heads of preschool education institutions are substantiated. The offered materials of the article represent practical value for heads of preschool education institutions, educators-methodologists, and future teachers of preschool education.

Keywords: leadership, leadership qualities, manager, pedagogical conditions of formation of leadership qualities of future heads of preschool education institutions.

\section{INTRODUCTION}

In the context of significant socio-economic changes, the system of human resource management technologies is becoming essential, especially the use of the potential of leadership influence. Since leadership is the highest form of professional leadership skills, to acquire professional competence, the head of a preschool institution must have developed leadership qualities. That is why specialists in administrative management need the development of leadership skills while studying in a higher education institution to further their development in professional activities. Leadership combines the processes of domination, subordination, influence, direction, consistency in the system of interpersonal relations in the group, ensuring the achievement of a group of specialists a certain goal and quality results. Important for our study is the conclusion formulated by N. Yakushko that «leadership is considered as a new management paradigm, the essence of which corresponds to modern realities and trends in society. The introduction of leadership principles in the system of professional training of future managers of preschool educational establishment should be based on the development of leadership potential of managers, which requires modernization of the defining parameters of the system of professional training of managers» (N. Yakushko, 2018).

\section{MATERIALS AND METHODS}

The following methods were used in the research process: theoretical: theoretical analysis of pedagogical literature; comparative analysis of facts, documents, views; empirical: pedagogical experiment (ascertaining, formative), diagnostic (questionnaire, conversation, testing, comparison, expert assessment); observational: (pedagogical observation, self-analysis), analysis of the obtained results.

The article presents the pedagogical conditions for the formation of leadership qualities of future heads of preschool education, which form the theoretical basis of the study are (systematic, personality-oriented, activity, dialogical, and competence approaches to the 
professional training of future heads of preschool education; provisions on the impossibility of cognition without motivation activities, the unity of consciousness and activity, the role of practice in the process of learning and the relationship of real-life and its cognitive activity, the concept of continuing education, personality-oriented approach to the educational process, theoretical foundations of the educational process in higher education, theoretical and practical provisions for professional activities and training of future heads of preschool education institutions; psychological and pedagogical foundations of the leadership development process).

The leading method of the research of this problem is the method of modeling, which allows considering this problem as a purposeful and organized process of improving professional, cultural, and managerial competencies of specialists in preschool education, they need for effective educational activities in preschool education.

\section{RESULTS AND DISCUSSION}

Leadership as a social phenomenon is studied in the activities of a certain group of people, including a small group. We agree with the researcher B. Goloveshko, who formulates the conclusion that the leader in a small group should direct informal interpersonal communication (B. Goloveshko, 2017), which is important for determining the leadership qualities of future heads of preschool education, one of the main tasks of which is to ensure the maintenance of coordinated teamwork. Based on the results of scientific research of V. Kremen, B. Goloveshko, the concept of «leader» is defined as the ability of the head of preschool education to play a central role in organizing joint activities and regulating relationships in the team, which delegates the right to make decisions in important situations; leads the team in achieving a certain goal, integrates and directs its activities (B. Goloveshko, 2017).

The scientist E. Ilyin defines the following features of a leader: he belongs to a group in which he occupies an influential and authoritative position; by his personal actions contributes to the achievement of goals and interests of the group; takes the initiative and responsibility; affects all members of the group who implement its decisions (E. Ilyin, 2000). According to J. Maxwell, «the leader is a person who knows the way, follows this path and shows it to others» (B. Goloveshko, 2017). This statement emphasizes the main characteristics of a leader, which are determined by scientists. Defining leadership as «position, personality and the process of involving followers in certain activities», researcher S. Kalashnikov notes that «the primary basis of leadership is the personality of the leader, his leadership qualities» (S. Kalashnikov, 2010).

Relevant for our study is the definition of the essence of the concept of «leadership qualities», proposed by A. Pilganchuk and V. Kuzmenko, who understand it as «personality qualities that provide effective leadership, individual and socio-psychological personality traits that affect the group and ensure the achievement of the goal (B. Goloveshko, 2017 and A. Pilhanchuk, V. Kuzmenko, 2012).

Formulating the goals of the article - theoretical substantiation and experimental verification of pedagogical conditions of formation of leadership qualities of future heads of preschool educational institutions. 
The experimental work was performed based on Kyiv University named after Borys Hrinchenko, Municipal Educational Institution of the Kyiv Regional Council «Kyiv Regional Institute of Postgraduate Education of Teachers».

Based on a study of the scientific literature on the nature of leadership, it has been found that leaders have the following qualities: a leader's lifestyle involves a combination of career and personal life; the leader does not stop in his development; the vocation of a leader is manifested in the use of abilities and acquired knowledge, skills, talent as a way of selfrealization in interaction with other people (N. Yakushko, 2018). A leader as a charismatic personality is characterized by the following personal qualities and skills: high level of mental abilities, broad public interests, maturity (N. Yakushko, 2018); organization, confidence in their actions and decisions, sense of dignity, energy, adequacy, balance, emotional and stress resistance, the ability to act quickly and thoughtfully in different situations and manage them, to succeed, to inspire others by their own example; has developed rhetorical abilities (can express his own opinion, convincing, has the skills of interpersonal communication); objectively assesses his abilities; ability to take care of one's appearance, mastery of pedagogical techniques (B. Goloveshko, 2017).

Based on the study of leadership concepts 0. Morgulets identified the following main approaches to leadership: an approach based on leadership qualities (the first, traditional approach, which assumes the presence of unique personality traits that he receives from birth, a high level of intelligence and education, expressive appearance, self-confidence, initiative, etc.; is the basis of other concepts); behavioral approach (assumes that leadership qualities can be successfully developed, not necessarily born a leader); situational approach (determines that the effectiveness of leadership directly depends on the specific situation, but the personal qualities and behavior of the leader are also important factors of leadership) (B. Goloveshko, 2017 and O. Morgulets, 2012).

Thus, the analysis of leadership qualities of the individual is based on the study of stable character traits of the individual, it is believed that the leader has certain innate traits that ensure the effectiveness of his activities. The basis of the behavioral approach is the classification of leadership styles and behavior, observation, and analysis of images of leadership behavior that are manifested in the specific actions of leaders. Determinant in the behavioral approach is the style of behavior of the leader with subordinates. The dynamics of behavior reflects what is the criterion for analyzing the activities of the leader: «statics, which involves the analysis of leadership qualities of the individual, or the dynamics based on the analysis of the leader's behavior» (N. Yakushko, 2018). The research results confirm the inexpediency of the advantage of a particular leadership style, confirm the need for flexible application of different leadership styles in specific situations (N. Yakushko, 2018).

In the context of the formation of leadership qualities in future heads of preschool education institutions, while studying in a higher education institution, it is necessary to consider the essence of the concept of "professional qualities of a leader». Scientists define the following basic provisions of the concept of «professional qualities»: «individual properties of the subject of activity, which are necessary and sufficient for its implementation at the normative level and which significantly and positively correlate with at least one or more of its main performance parameters - quality, productivity, reliability» (A. Karpov, 2003); 
«Personality qualities that determine productivity, quality, performance» (E. Zeyer, 2003); «Individual qualities of the subject of activity, influencing the efficiency of activity and the success of its development» (V. Shadrikov, 1982); «A set of professional qualities that serve the successful implementation of professional activities, effective solution of professional tasks, personal and professional growth and improvement» (M. Akhmetova, 2004 and B. Goloveshko, 2017).

Researchers M. Klishchevska and G. Solntseva in the context of defining professionally important qualities use the concept of «individual and personal characteristics», in particular - the necessary and sufficient qualities. The necessary qualities are manifested in such features of the leader, which allow to describe it in all its variety of manifestations, determine the effectiveness of the leader; sufficient qualities distinguish it from others (B. Goloveshko, 2017 and M. Klishchevskaya, G. Solntseva, 1999).

Z. Gaponyuk identifies the following groups of potential qualities of a leader: generalprofessional, creative, socio-psychological, social-communicative (Z. Gaponyuk, 2008). The general professional qualities include theoretical knowledge, practical experience, systematization of professional issues, ability to adapt to the situation, ability to prognostic activities, quality performance of professional duties, responsibility, ability to manage the team, highlight the main and secondary, properly manage their own sometimes and distribute responsibilities in the team. Creative qualities combine creativity, initiative, openness to change, integrativeness; ability to develop and implement innovative educational projects and programs, to train preschool education specialists for innovative educational activities, to use research activities in the management of the educational process, and methodological work. Socio-psychological qualities combine: creating a comfortable, safe, developmental, inclusive educational environment; humanism, flexibility, tolerance, positive thinking, the ability to be an example to follow, establish interpersonal contacts, have confidence and commitment to themselves, understand people, and influence their activities and behavior, implement an individual approach to each specialist, determine the optimal pace of work, justify their own opinion, persuade, form a positive attitude to the activities and behavior of the leader; emotional and stress resistance, the tendency to analysis and introspection, application of reflective practices. Socio-communicative qualities include the ability to communicate and establish professional contacts, assertiveness (the ability to defend their own opinions, justify their own opinions, show respect for the interests of the whole team and individuals, their personal space), to manage communication between team members, the ability to use channels and mechanisms of communication, technologies of communicative activity.

In the context of combining an approach based on leadership qualities of personality, behavioral and situational approaches, it is important to determine the components of the structure of leadership qualities proposed by V. Lokshin: general personal qualities of a leader that form his value system, attitude to people and the world; leader behavior that involves mutual understanding, perception, evaluation, etc.; a situation that determines the success of the leader (V. Lokshin, 2013).

The results of the research confirm the importance of the following leadership qualities of personality: sociability, activity, initiative, persistence, self-control, ability to work, 
observation, organization, independence, persuasiveness, determination, erudition, selfconfidence, emotional attractiveness, ability to persuade Goloveshko, 2017 and A. Zorina, 2009); intelligence, sociability, empathy, kindness (B. Goloveshko, 2017 and T. Vezhevych, 2001).

B. Goloveshko notes that «leadership qualities needed by a specialist to achieve a leadership position in specific conditions, the implementation of effective leadership influence and the realization of leadership potential, play a role in the activities of the leader» (B. Goloveshko, 2017). Analyzing the specifics of professional activity, we can identify qualities that should take into account the following factors in the formation of leadership qualities of future leaders of Preschool educational institution (next PEI): social and educational challenges; features of the social and educational environment; the purpose and objectives of management, professional roles performed by the leader, etc.

Based on the analysis of the scientific literature, we have identified the essence of the concept of «leadership qualities», which we understand as a combination of individual and socio-psychological personality traits that ensure the achievement of management goals in a particular situation, effective leadership, and leadership potential.

Researchers V. Stadnyk and M. Jochna note that «for the successful work of the team it is important not only the relationships formed in it but also how their activities are directed, what forms of influence are used to encourage people to work productively. These issues belong to the competence of the leader who leads the team and uses power to influence people's behavior (B. Goloveshko, 2017 and V. Stadnyk, M. Jochna, 2003). Giving the head formal power is insufficient to perform leadership functions, which necessitates the formation of leadership qualities of the future head of the preschool institution to achieve the goals of management and educational activities.

Researchers G. Hernes-Broome, R. Hughes noted that the approach that involves the formation of leadership qualities will remain relevant in the future, however, changing the set of such qualities will be accompanied by the transformation of the competitive environment, the factors of which are «global competition, information and communication, and digital technologies, the growing role of teams in achieving professional goals, the need to meet the needs of society, community, subjects of the educational process in the efficiency, flexibility, mobility, predictability of organizations» (B. Goloveshko, 2017 and G. Hernez-Broome, R Hughes L., 2004).

Important for our study is the analysis of the multifunctional concept of «management», which is considered by scientists as one that is used mainly to characterize the management processes of business organizations (enterprises). «Management» is an extremely broad and multidimensional concept. Etymologically, management comes from the Latin word «manus» - hand. Initially, this word meant the ability to carefully manage the household, skillfully own the means of labor, work skillfully. With the advent of many types of work, with the deepening of specialization, there was a need for activities that integrated the work of many individual performers. Accordingly, the meaning of the concept of «management» was transformed. This word has absorbed all the numerous requirements for management as a science, art of business, and style of work (Z. Pushkar, B. Pushkar, 2017).

Given the functional responsibilities of the head, appropriate requirements are formed for his 
personal and professional qualities. The head must have a set of knowledge, skills, and abilities to manage an educational institution or its structural unit, have a willingness to manage, critical thinking, experience, values, which will ensure the quality and efficiency of his professional activity.

Using the provisions of the competency approach, T. Batalova defines the following functional roles of a modern leader: «the ability to be a manager-leader, to intensify the activities of followers; ability to manage the team; the ability to be an example to follow, to influence people to achieve certain goals; ability to use modern methods and technologies in the process of managing an educational institution, including information and communication; ability to work in a team, ability to work effectively as a team member, its leader; ability to be a strategist», to transform their activities and the activities of preschool education; ability to innovative and creative thinking, the realization of creative potential in professional activity, management of innovative educational activity; ability to distinguish opinions and arguments, evaluate them, establish cause-and-effect relationships; ability to continuous professional development (B. Goloveshko, 2017 and T. Batalova, 2004).

Thus, the combination of the above positions involves the formation of a set of personal qualities of the head of the educational institution, which are the basis for the implementation of his leadership in professional activities, managerial influence on participants in the educational process.

In the process of developing curricula, it is important to analyze the current state of management of preschool education and forecast future challenges (O. Romanovsky, O. Ponomarev, O. Ignatiuk, etc., 2011).

The synergetic paradigm of higher school pedagogy presupposes that in numerous bifurcation points the student should be influenced to direct the process of professional training, formation of leadership qualities of personality, the realization of the individual trajectory of professional and personal development of future heads of preschool education institutions. In the context of the synergetic paradigm, higher education institutions involve practitioners in the educational process, the participation of future leaders of PEI in the preparation and implementation of methodological activities, the work of professional associations of PEI leaders (workshops, pedagogical studies, workshops, round tables). training, etc). The involvement of future leaders of PEI in the preparation and conduct of such activities will contribute to the formation of their leadership qualities.

Let's define and characterize the structural components of leadership qualities of future leaders of PEI, namely: motivational-value, integrative-activity, directional-activity, emotional-reflexive. In the process of scientific research, we used the provisions of a study conducted by B. Goloveshko (B. Goloveshko, 2017) on the structural components of leadership qualities of future leaders and their content.

Motivational and value component of leadership qualities of the future head of PEI combines the focus on new achievements and goals, the formation of the level of claims and values to the management of the leader, flexibility, positivity, and constructiveness of professional thinking; openness to change, innovation; the need for self-realization in professional activities, the focus on recognition, the desire to increase education and professional development and self-improvement. The integrative-activity component of 
leadership qualities of the future head of PEI combines initiative, energy; ability to attract, activate, organize and unite the team; systematic management; communicative competence. The directional and activity component of the leadership qualities of the future head of PEI is manifested in the ability to model the educational environment, the activities of the team, the professional development of staff, the expected results of educational activities. The emotional-reflexive component of leadership qualities of the future head of PEI is manifested in emotional and ethical competence, which combines the ability to understand their own emotions and their causes, the impact of a particular emotion on human behavior; attention to the manifestation of emotions of others; ability to objectively interpret the external manifestation of emotions; ability to activate, maintain or deactivate their own emotions; ability to activate a certain emotion, reduce the intensity of unwanted emotion of another person (B. Goloveshko, 2017).

Thus, the motivational and value component of leadership qualities of the future head of PEI characterizes a set of motives and values that determine the success and effectiveness of management activities of the leader of the educational institution; integrative-activity component of leadership qualities of the future head of PEI is characterized by a set of organizational and communicative abilities that provide the ability of the future head of PEI to integrate the activities of the group as a single team; the directional-activity component of leadership qualities of the future head of PEI is characterized by a complex of abilities on decision-making and establishment of the purposes providing purposeful educational activity, professional development of collective; emotional-reflexive component of leadership qualities of the future head of PEI is characterized by a set of abilities to recognize and manage their own emotions and the emotions of others, providing his emotional stability and stress resistance, the ability to express itself as a standard.

The study found that the general basis for the formation and development of the manager as a specialist, a competent leader is his intellectual qualities, which determine the success, quality, and effectiveness of his management in influencing the team to achieve certain goals and objectives. Solving the problem of forming the leadership qualities of future heads of preschool education institutions required clarification of the criteria, indicators, and levels of formation of leadership qualities of future leaders of preschool education. In our study, we proceed from the fact that the definition of criteria and indicators, levels of leadership qualities of future leaders of PEI combines the following structural components: motivational-value, integrative-activity, directional-activity, emotional-reflexive.

We have identified the criteria and indicators of the formation of leadership qualities of future leaders of PEI, presented in the study of B. Goloveshko, according to the above components (B. Goloveshko, 2017). Motivational and value component of leadership qualities of the future head of PEI characterizes a set of important motives and values that determine the success and effectiveness of the head of PEI as a leader of the organization's staff. The following indicators of motivational and value criterion of formation of leadership qualities of future leaders of PEI are determined: the need to achieve the goal, motivation to succeed, professional orientation (B. Goloveshko, 2017). The integrative-activity component of the leadership qualities of the future head of the PEI characterizes a set of organizational and communicative abilities that provide the ability of the future head of the PEI to integrate 
the activities of the group as a single team. Organizational and communicative abilities are determined by indicators of integrative-activity criterion (B. Goloveshko, 2017). The directional and activity component of the leadership qualities of the future head of the PEI is characterized by a set of decision-making and goal-setting abilities that ensure the purposefulness of the team as a whole. Indicators of goal-setting criterion determine the ability to set goals, plan, and make decisions (B. Goloveshko, 2017). The emotional-reflexive component of leadership qualities of the future head of PEI is characterized by a set of abilities to recognize and manage their own emotions, the ability to influence the emotions of others, the ability to show themselves as an example to follow. Indicators of emotionalreflexive criterion determine the ability to understand their own and others' emotions, manage their own emotions, to influence the emotions of others (B. Goloveshko, 2017).

The ascertaining stage of the research was carried out with the 5th year students of the specialty 012 «Preschool education» of the second (master's) level of higher education of the Pedagogical Institute of Kyiv University named after Borys Hrinchenko. The purpose of the ascertaining stage of the experiment was to determine the level of formation of leadership qualities of future leaders of PEI. Following the defined components, criteria, and indicators, we distinguish the following levels of formation of leadership qualities of future leaders of PEI: high, sufficient, initial. We characterize the levels of formation of leadership qualities of future leaders of PEI in accordance with certain criteria and indicators. Indicators of the motivational-value criterion are the need to achieve the goal, motivation to succeed, professional orientation. The high level of need to achieve the goal implies the desire for new achievements, a high degree of persistence in achieving goals, the presence of a developed spirit of rivalry and aspirations, the manifestation of positive emotions in the process of achieving the goal. A sufficient level of need to achieve the goal is manifested in the desire for new achievements, a sufficient degree of persistence in achieving goals, the desire to do the job well, the process of achieving the goal does not cause special emotions. The initial level of need to achieve the goal involves a sense of satisfaction with the achieved or lack of reasoning about it, the initial degree of persistence in achieving goals, lack of spirit of rivalry, the manifestation of negative emotions about actions aimed at achieving the goal.

A high level of motivation to succeed implies the need for self-realization in the process of professional activity, a clear focus on recognition in the public environment, the presence of a clearly articulated positive result. A sufficient level of motivation to succeed is manifested in the need for self-realization in the process of professional activity, a sufficient degree of focus on recognition in the social environment, an abstract idea of achieving a positive result. The initial level of motivation to succeed implies the initial degree of need for selfrealization in the process of professional activity, there is no focus on recognition in the public environment, focus on finding ways to solve or avoid problematic/negative situations in management.

A high level of professional orientation implies the presence of a high degree of significance of the professional activity, the desire to increase the level of education and professional skills, awareness of the future head of PEI leadership as a type of management interaction between leaders and followers. A sufficient level of professional orientation indicates the presence of high significance for the person of his professional activity or the desire to increase the 
level of education and professional skills, leadership is considered outside the professional competence of the future head of PEI. At the initial level, the importance of professional activity, the desire to increase the level of education, understanding the essence of the concept of «leadership», its role in the management of the future head of PEI is not traced.

Organizational and communicative abilities are determined by the indicators of integrativeactivity criterion.

The high level of organizational skills presupposes initiative and social activity, the ability to attract and activate members of the team as the future head of the PEI, a systematic approach to the analysis of their work and educational activities of the educational institution. A sufficient level of organizational skills is manifested in a sufficient degree of initiative and social activity, fragmentary ability to attract and activate team members, systematic analysis of the work of the future head of PEI, and educational activities of the educational institution. The initial level of organizational skills involves the initial degree of initiative and social activity, there is no trace of the ability to attract and activate team members, there is chaos in the analysis of work.

Indicators of goal-setting criterion determine the ability to set goals, plan, make decisions. A high level of goal-setting abilities implies a high degree of ability to define goals and present the modeled phenomenon, its structure, forecasting options for solving problems. A sufficient level of goal-setting abilities indicates a sufficient degree of ability to define goals and present the modeled phenomenon, its structure, forecasting options for solving problems. The initial level of goal-setting abilities presupposes the initial degree of ability to define goals and present the modeled phenomenon, its structure, forecasting options for solving problems.

A high level of planning skills implies a conscious tendency to plan management and educational activities, a high degree of ability to achieve goals, planning is characterized by realism and hierarchy. A sufficient level of planning skills implies readiness to plan managerial and educational activities, a sufficient degree of ability to achieve the goal, realistic and hierarchical planning can be traced. The initial level of planning skills is manifested in the immaturity of skills to plan management and educational activities, the activity is characterized by situationality and inconsistency.

A high level of decision-making skills requires determination and balance in their decisionmaking, change of decisions (if necessary), adequacy of assessment of the consequences of decisions, objective and impartial attitude to the results of management. A sufficient level of decision-making skills is characterized by the formation of readiness to make decisions, prudence, and at the same time - impulsiveness in decision-making, lack of flexibility in their adjustment, a sufficient degree of adequacy to assess the consequences of decisions, errors. The initial level of decision-making skills is characterized by fluctuations and impulsiveness in decision-making, decisions remain unchanged or canceled, the initial degree of adequacy of evaluation of the results of decisions, errors are not taken into account.

Indicators of the emotional-reflexive component determine the ability to understand their own and others' emotions, control their own emotions, the impact on the emotions of others.

A high level of understanding of one's own emotions presupposes a high degree of awareness of one's own emotions and their causes, the influence of a particular emotion 
on the behavior of the future head of PEI. A sufficient level of understanding of one's own emotions presupposes a sufficient degree of awareness of one's own emotions and their causes, the influence of a particular emotion on the behavior of the future head of PEI. The initial level of understanding of one's own emotions indicates the initial degree of attention to one's own emotions, the causes of emotions are mostly not interpreted, the influence of a particular emotion on the behavior of the future head of PEI is not realized.

A high level of understanding of other people's emotions implies a high degree of attention, sensitivity, tact to the emotions of others, the ability to objectively interpret the external manifestation of emotions, accompanied by a manifestation of communicative activity to understand other people's emotions. A sufficient level of understanding of other people's emotions implies a sufficient degree of attention, sensitivity, tact to the emotions of others, the ability to objectively interpret the external manifestation of emotions, accompanied by a manifestation of communicative activity to understand other people's emotions. The initial level of understanding of other people's emotions indicates that the emotions of others are fixed chaotically, the interpretation of the external manifestation of emotions is superficial.

A high level of management of one's own emotions implies the ability to control the external manifestation of one's own emotions, a high degree of ability to activate, maintain or deactivate one's own emotions. A sufficient level of management of one's own emotions is manifested in the ability to control the external manifestation of one's own emotions, a sufficient degree of ability to activate, maintain or deactivate one's own emotions. The initial level of control of one's own emotions is manifested in the initial stage of control of the external manifestation of one's own emotion, the ability to activate, maintain or deactivate one's own emotion.

A high level of influence on the emotions of others implies a high ability to activate the necessary emotions of another person and a high degree of ability to reduce the intensity of unwanted emotions of another person. A sufficient level of influence on the emotions of others implies a sufficient degree of activation of the necessary emotion of another person, reducing the intensity of his unwanted emotions. The initial level of influence on the emotions of others is manifested in the low ability to activate the necessary emotions of another person, reducing the intensity of his unwanted emotions.

Thus, the defined criteria, indicators, and levels of formation of leadership qualities of future leaders of PEI are the basis for the ascertaining stage of the experiment, which involves the use of a set of diagnostic techniques; further substantiation of pedagogical conditions on the research problem, which are presented in the following paragraphs.

Thus, the defined criteria, indicators and levels of formation of leadership qualities of future leaders of PEI are the basis for the ascertaining stage of the experiment, which involves the use of a set of diagnostic techniques; further substantiation of pedagogical conditions on the problem of research, which are presented in the following paragraphs.

Determining the criteria, indicators, and levels of leadership qualities of the respondents involved the use of the following research methods: interview, observation, testing.

The experimental study involved 56 respondents: 23 students of the experimental group (EG) and 23 leaders of PEI control group (CG). In the process of the ascertaining stage of the experiment the comparison of the formation of leadership qualities of future leaders of PEI 
(students of V course of specialty 012 «Preschool education» of the second (master's) level of higher education) and leaders of PEI who studied at advanced training courses in the specialty «Directors of preschool education institutions» was made. To determine the level of formation of leadership qualities, a set of diagnostic methods was used: the method «Need to achieve the goal» (Yu. Orlov) (O. Yeliseyev, 2003), «Methods for diagnosing motivation to succeed» (T. Ehlers) (V. Rozanova, 1999 ), «Questionnaire of terminal values (OTeC)» (I. Senin, 1991), the method of «Communicative and organizational tendencies (KOS-2)» (V. Sinyavsky, B. Fedorishin, and N. Fetiskin, 2002), the method of «Self-regulation style» behavior» (V. Morosanova, 1995), test for emotional intelligence «Emin» (D. Lusin, 2006).

The ascertaining stage of the pedagogical experiment involved assessing the level of formation of respondents' leadership qualities according to certain components. The level of formation of the motivational-value component was determined by the level of manifestation of the need to achieve the goal, motivation to succeed, and the definition of the hierarchy of the dominant sphere of life. To determine the level of manifestation of the need to achieve the goal, the method of «Need to achieve the goal» was used by Yu. Orlov. Determination of motivation to succeed was carried out using the «Methods of diagnosing motivation to succeed» by T. Ehlers. Psychodiagnostics of the hierarchy of the dominant sphere of life was carried out by ranking and further analysis of the products of activity (among the working managers of PEI - conversation) and the use of «Questionnaire of terminal values (OTEC)» by I. Senin.

Among the respondents, at the beginning of the study, there was a survey. So, for example, to the question «What motives motivate you to a managerial position in PEI?» we determined that professional - 44 respondents $(78,6 \%)$; cognitive - 41 respondents $(73,2 \%)$; moral -31 respondents (55,4\%); material -8 respondents $(14,3 \%)$; the rest 4 respondents $(7,1 \%)$. To the question «Would you be able to self-realize in the profession through management?» answered: «yes» - 35 people $(62,5 \%)$; «no» - 16 people $(28,6 \%)$; «didn't think about it - 5 (8,9 \%) (fig. 1).

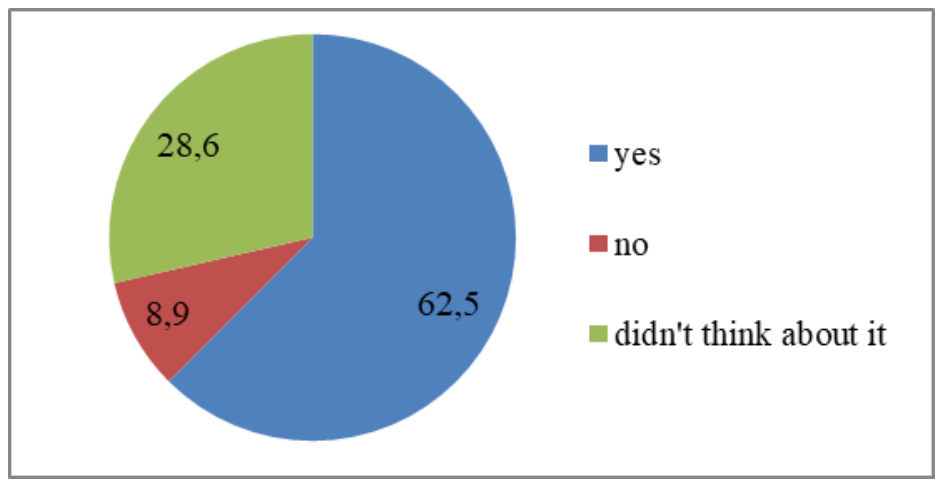

Fig. 1. Results of the survey «Would you be able to self-realize in the profession through management?»

Regarding the qualities that ensure the identification of organizational and managerial skills in the professional activities of the head of PEI, we want to note that the opponents were presented as follows: intellectual, business, specially professional, emotional, 
volitional, moral, and aesthetic, qualities that characterize the attitude to life and more. Thus, we found that 47 people $(83,9 \%)$ chose intellectual qualities; 39 people $(69,6 \%)-$ business, 38 people $(67,9 \%)$ - specially professional; 39 people $(69,6 \%)$ are emotional and volitional; 39 (69,9\%) - moral and ethical; 29 people (51,8 \%) - qualities that characterize the attitude to life and 1 person (1,8\%) chose other (fig. 2 ).

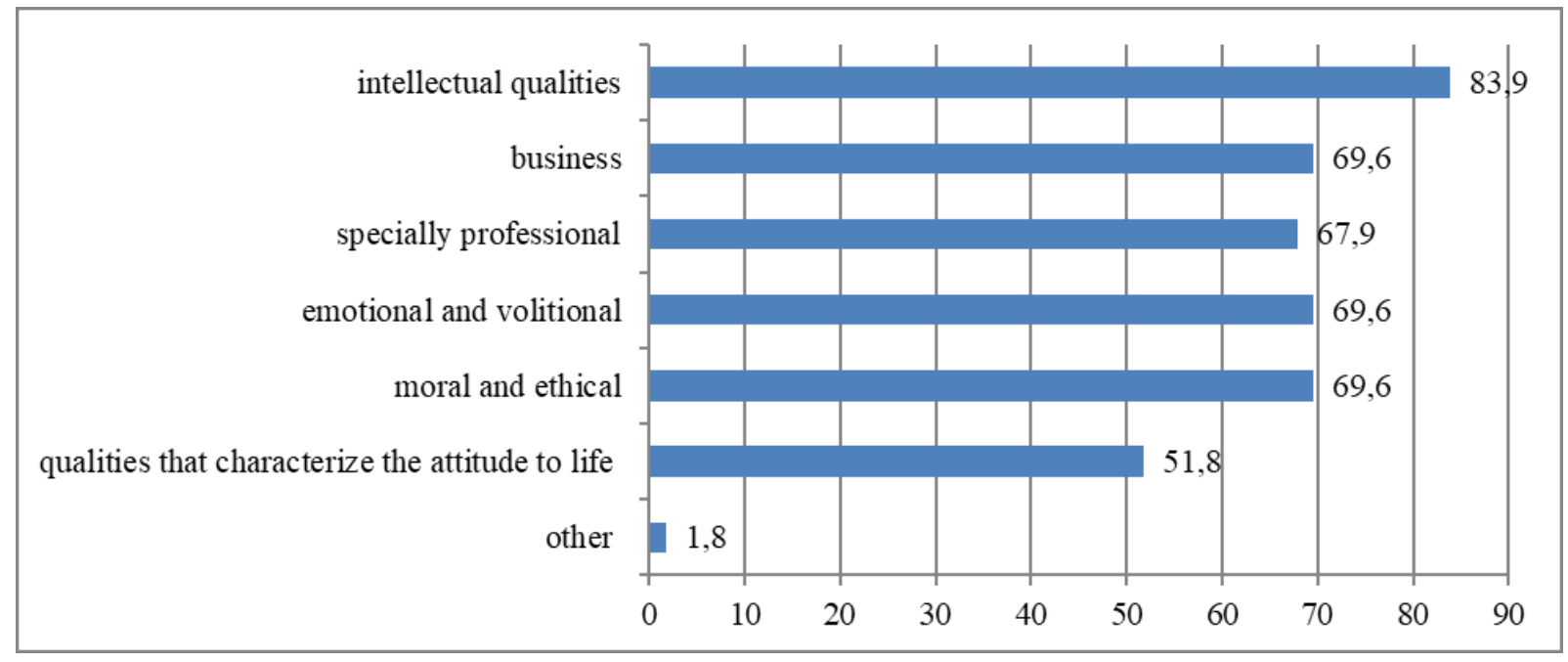

Fig. 2. The results of the survey «Choose the qualities that ensure the identification of organizational and managerial skills in the professional activities of the head of PEI»

In the course of carrying out the ascertaining stage of the experiment, it is found out that the summarized indicators of components of formation of leadership qualities of future leaders of PEI at the ascertaining stage of experiment make 20,54\% of high level, $55,7 \%$ of sufficient and $23,8 \%$ of initial levels that defines necessity of development and introduction of pedagogical conditions of their formation in the educational process of higher education institution. The results of the observational experiment prove that the future leaders of PEI have an insufficient level of leadership qualities. The current leaders of PEI show a higher level of development in all indicators of leadership development than students. The conducted analysis allows asserting about the necessity of definition and purposeful introduction of pedagogical conditions of formation of leadership qualities of the future heads of PEI in the educational process of establishments of higher education.

The implementation of the theoretical justification of the pedagogical conditions for the formation of leadership qualities of future leaders of PEI involves the disclosure of the essence of the concept of «pedagogical condition». Based on the analysis of scientific literature, the following basic provisions defining the essence of concept «pedagogical condition» are found out: «the forms, methods, material conditions, real situations which have objectively developed or subjectively created are necessary for the achievement of the concrete pedagogical purpose» (O. Infantry); «A set of objective possibilities of the content of education, methods, organizational forms and material possibilities of its implementation, which ensure the successful solution of the task» (O. Fedorova); a set of reasons, circumstances, any objects that affect the dynamics and final results of development, education, and training 
of the individual, can accelerate or inhibit these processes (N. Ippolitova, N. Sterkhova); a set of means, circumstances that contribute to the development or inhibition, effective implementation of the educational process (O. Brazhnych). Thus, based on the provisions of scientific works of O. Brazhnych, N. Ippolitova, O. Pekhota, N. Sterkhova, O. Fedorova, the basic concepts that define the content of the category «pedagogical conditions» are defined, namely: causes, circumstances, situations, factors; purpose, forms, methods, means, material conditions; efficiency of the educational process; results of development, education, training of the person; quality of preschool education.

In our study, the concept of «pedagogical conditions for the formation of leadership qualities of future leaders of preschool education» is understood as necessary to achieve specific educational goal forms, methods, tools, material conditions that combine a range of causes, circumstances, objects, situations, which objectively formed or subjectively created, and affect the dynamics and results of development, education, training of the individual, can accelerate or inhibit these processes, contribute to the effective implementation of the educational process or inhibit it, ensure the quality of preschool education.

Based on the provisions and results of the study conducted by B. Goloveshko, the pedagogical conditions for the formation of leadership qualities of future leaders of PEI are theoretically substantiated, in particular: motivational and value orientation of future leaders of PEI on successful management based on actualization of positive experience, creation of success situation; ensuring the mastery of the future leaders of PEI system of practically oriented, integrated knowledge about the phenomenon of leadership based on cognitive activation of students and their critical understanding of educational material; the use of personalityoriented technologies aimed at forming leadership skills in future leaders of PEI; formation of emotional and ethical competence of future leaders of PEI (M. Akhmetova, 2004).

We characterize the first pedagogical condition for the formation of leadership qualities of future leaders of PEI - motivational and value orientation of future leaders of PEI for successful management based on the actualization of positive experience, creating a situation of success.

According to the provisions formulated by A. Rean, the motive is considered as an internal motivation of the individual to activity, which is realized in the activity, communication, and behavior, associated with the satisfaction of a certain need. According to the scientist, motivation is an expression of personality orientation and combines stable motives in a certain hierarchy. M. Rokych notes that values are strong beliefs about appropriate ways of behaving and achieving the ultimate goal. The scientist defines terminal values, which are values-goals, which are manifested in the belief that the ultimate goal of an individual's existence is worth striving for it; instrumental values, ie values-tools that are based on the belief that the behavior and personal qualities of the individual corresponding to a particular situation. Based on the analysis of psychological and pedagogical literature, the following groups of motives are distinguished by the content of activities: social, cognitive, professional, material, and procedural. In the context of the study of the motivational and value orientation of future leaders of PEI on successful professional activity, we focus on the professional motives for the formation of their leadership qualities. B. Goloveshko understands professional motivation as a system of stable motives that motivate a person to 
master the knowledge, skills, and abilities of future managers, the formation of professional competence (M. Akhmetova, 2004).

Exploring professional motivation, H. Heckhausen identifies direct and indirect interests. The direct ones include specific professional interests that are manifested in the interest in the process and result of work, its objects, products, services; general professional interests, which include interest in the profession and its attractive features; romantic interest based on interest in the uniqueness of the profession; situational interest aimed at understanding the atypical properties of the profession (M. Akhmetova, 2004 and M. Didenko, 2013). Indirect interests related to the social and organizational characteristics of the profession combine cognitive interest, which is manifested in the desire to acquire new knowledge; prestigious interest in the pursuit of career growth and public recognition; interest in spiritual enrichment and intellectual development; uncertain interest, which is manifested in emotional satisfaction with the profession (M. Akhmetova, 2004 and M. Didenko, 2013).

$H$. Heckhausen considers the awareness of usefulness, the need of the individual in a particular field of activity as a motive of duty, combining several components, such as professional responsibility for their responsibilities and requirements of the profession, innovation, desire for self-realization, and self-improvement in the profession, altruistic aspirations (M. Akhmetova, 2004 and M. Didenko, 2013).

B. Goloveshko notes the relationship between cognitive and professional motives. The desire to succeed in professional activities leads to the emergence of an internal motive to acquire knowledge. Activation of cognitive motives contributes to the increase of professional motives, the formation of confidence of future leaders in their abilities, has a positive effect on their emotional attitude to future professional activities. According to the scientist, the combination of professional competence and leadership qualities are integral components of the management of the future head of PEI (B. Goloveshko, 2017). Important components of motivation of future leaders of PEI to successful professional activity are aspiration to constant personal and professional development, the realization of professional abilities, recognition of professionalism by other experts; focus on career development (B. Goloveshko, 2017).

The second pedagogical condition for the formation of leadership qualities of future leaders of PEI is to ensure the mastery of a system of practically oriented, integrated knowledge about the phenomenon of leadership based on cognitive activation of students and their critical understanding of educational material. The implementation of this pedagogical condition involves the definition of the theoretical foundations of the study of the phenomenon of leadership by future leaders of PEI. In the process of studying the material on leadership, it is advisable to use interactive forms and methods of learning, in particular: «brainstorming», thematic discussion, training, role play, and more.

The third pedagogical condition for the formation of leadership qualities of future leaders of PEI is the use of personality-oriented technologies aimed at the formation of future leaders of PEI leadership skills. The formation of individual-personal and sociopsychological qualities of future leaders of PEI is based on the following leadership skills: effective communication, time management, decision-making, managerial influence, team building, coaching, conflict management (M. Akhmetova, 2004). Implementation of effective 
communication is the basic professional competence of the head of PEI, which provides communication and feedback with the subjects of the educational process, the exchange of information vertically and horizontally, clear and logical presentation of their opinions and opinions orally and in writing; ability to formulate and justify their own position, informing employees about the tasks and expected results of activities; consulting and informing the public, readiness for public speeches, partnership with colleagues and heads of other institutions and organizations, the ability to listen, accept the ideas and positions of others, to find a compromise solution; discussion of different positions, views, and points of view; negotiation, ability (M. Akhmetova, 2004 and T. Batalova, 2004). The formation of effective communication skills contributes to the successful performance of the duties of the head of the PEI, the functions of the leader in terms of integration, purposefulness, and effective achievement of the goals of the PEI staff.

The specifics of the activity of the head of PEI presupposes the formation of time management skills, goal setting, and effective management of one's own time and the time of subordinates. L. Kucher notes that «the readiness of the manager to work effectively is determined by the practice of his daily activities, and the rational use of working time is crucial for the formation of leadership style. Clear establishment of planning periods contributes to a more accurate assessment of the situation as a whole, facilitates the selection of the main, increases the level of performance and helps the manager to make the right decision on how best to use working time» (T. Vezhevich, 2001).

Relevant for the formation of the above skills are defined by N. Alyushina provisions on individual or role-time management of leaders, such as awareness of their personal goals, their consistency with the overall goals of the organization; ability to plan own time based on fixing of the planned tasks, terms, resources; ability to set-top priorities; delegation of tasks to subordinates, the ability to rationally and efficiently use their time; ability to selfanalysis, self-development and creative activity, desire to improve own skills and abilities, to perform work as quickly and efficiently as possible; skills of «energy self-management», the ability to maintain a balance between work and rest, to make optimal use of self-motivation methods; ability to self-control, overcoming obstacles and solving unpredictable problems (I. Adizes, 2009).

Performing the function of a leader in targeting the activities of PEI staff involves the formation of his decision-making skills, which ensures the successful and effective performance of duties by PEI employees, creating a safe, comfortable, developmental, inclusive educational environment of PEI.

Implementation of managerial influence involves the purpose of the pedagogical staff of PEI to achieve certain educational goals, the formation of the ability to mobilize the efforts of each employee and the team as a whole to ensure the quality of preschool education, combining quality goal setting, quality of the educational process, quality of educational result quality of psychological and pedagogical conditions, quality of management of preschool education institution (S. Boyko, 2008).

The formation of coaching skills ensures the high-quality and effective performance of labor functions by the head of PEI, contributes to the achievement of specific personal and professional educational goals. Foreign researchers M. Atkinson, J. Whitmore, R. Chois note 
that «coaching reveals a person's potential and helps him to achieve maximum efficiency» (Z. Gaponyuk, 2008), «helps to acquire the skills needed to realize creative abilities, increase personal effectiveness in the process of achieving the goal, to learn individual values, teaches to support employees in unleashing their potential» (M. Akhmetova, 2004).

Execution of labor functions of the head of PEI presupposes the formation of conflict management skills, which combines the following components: understanding the essence of the conflict; objective attitude to all parties to the conflict, manage their own and their emotions; provide an opportunity to express their arguments; understand and take into account the interests and motives of the parties (B. Goloveshko, 2017); to search for different options for reconciling the interests of the parties; provide flexibility, positivity, show emotional stability, have the ability to solve problems of each party, find compromises, offer different ways of agreement between the parties on a positive solution; be able to direct the communication of the parties to the conflict to determine the essence of the problems, ways to solve them, express constructive suggestions, their analysis, and discussion, coordination.

To influence the individual-personal and socio-psychological qualities of the individual, allowing the manager of administrative activities to understand and manage their own and others' emotions.

The fourth pedagogical condition for the formation of leadership qualities of future leaders of PEI is the formation of their emotional and ethical competence, which is manifested in the ability to realize personal feelings and emotions, to manage their own emotional states; ability to conscious, constructive and environmental interaction with participants in the educational process and local communities; ability to understand and appreciate the interdependence of the subjects of the educational process (K. Voronina, 2009).

The formation of emotional and ethical competence of future leaders of PEI involves mastering knowledge about the types and intensity of emotions, the reasons for their occurrence; modern forms, methods, technologies and teaching aids that promote the development of selfattention, self-regulation, emotion management and understanding; methods of dialogue and polylogue, conscious and empathic listening, non-violent communication; developing skills to understand the diversity and uniqueness of different cultures in society, differences between people, methods of prevention, overcoming and transformation of conflicts; awareness and constructive response to the manifestations of emotions without condemnation; mastering the ways of self-preservation of mental health, awareness and management of one's own emotions; constructively respond to stress, conflict situations, promote understanding of the subjects of the educational process; apply the practices of concentration, conscious emotional response, choose and implement appropriate emotional response depending on the communicative situation; organize a dialogue and polylogue with participants in the educational process and community representatives, respect their rights and social values; apply in discussions of educational, social and life problems methods of conscious and empathic listening and nonviolent communication; apply in the educational process the practice of critical thinking, awareness and understanding of other people's emotions; to take into account in communication cultural and personal differences of interlocutors, their advantages and limitations, to show understanding and empathy, to promote reconciliation (K. Voronina, 2009). 
Thus, as a result of scientific research, the pedagogical conditions for the formation of leadership qualities of future heads of preschool education institutions have been identified and substantiated, which will contribute to the formation of their professional competence and require experimental verification of their effectiveness in the educational process. During the formative stage of the experimental study in the process of training future leaders of PEI in higher education institutions, four pedagogical conditions were implemented to positively influence the level of formation of motivational-value, integrativeactivity, directional-activity, and emotional-reflexive components of leadership qualities. . The implementation of pedagogical conditions was carried out in the form of problem and review lectures, seminars-discussions and practical training sessions within ten separate content modules, which were defined following the pedagogical goals.

Thus, the formative stage of the experiment involved the introduction of pedagogical conditions for the formation of leadership qualities of future leaders of PEI. To track the dynamics of the formation of leadership qualities of future leaders of PEI, a control phase of the experiment was conducted, which involved re-diagnosing certain components and tracking the dynamics of change.

After the formative stage of the experiment, the positive dynamics of all components of the levels of formation of leadership qualities of future leaders of PEI are traced. At a high level of growth of indicators of formation of leadership qualities of future leaders of PEI makes $11,66 \%$ (from $20,54 \%$ to $32,2 \%$ ). At a sufficient level, there is an increase in indicators by $7,75 \%$ (from $55,7 \%$ to $63,45 \%$ ); at the initial level, there was a decrease in indicators by $0,5 \%$ (from $23,8 \%$ to $23,3 \%$ ). The overall growth rate of leadership qualities of future leaders of PEI is $18,91 \%$, which confirms the effectiveness of the introduction of pedagogical conditions for the formation of leadership qualities in future leaders of preschool education.

The results of the pedagogical experiment confirm the expediency of introducing the developed pedagogical conditions for the formation of leadership qualities in the process of professional training of future heads of preschool education institutions in higher education institutions.

\section{DISCUSSIONS}

Based on the analysis of the scientific literature, it was found that scientists pay special attention to the study of leadership problems in management (J. Antonakis, L. Bolman, R. Birnbaum, B. Goloveshko, T. Deal, D. Goleman, J. Ilias, J. Kotter, K. Levin, S. Nestulya, X. Owen, R. Presiosi, R. Stenberg, O. Yatsenko, etc.), psychology (T. Bendas, K. Voronina, T. Gura, V. Zazykin, L. Karamushka, B. Parigin, L. Pochebut, I. Meizhis, N. Radina, S. Taylor, etc.), pedagogy (D. Alfimov, I. Drach, S. Kalashnikov, V. Karmanenko, V. Moroz, O Romanovsky, R. Sopivnyk, V. Yahodnikova, etc.). The pedagogical intelligence of V. Lokshin, T. Makhina, S. Novikova, O. Romanovsky, V. Salyakhov, N. Yurtaeva, O. Yatsenko is devoted to the topic of development of leadership qualities in future managers, and M. Hasanova, B. Goloveshka, I. Drach, S. Kalashnikova, G. Tymoshko.

Determination of pedagogical conditions of formation of leadership qualities of future leaders of PEI is carried out by us based on results of scientific researches on the essence of pedagogical conditions of professional training in $\mathrm{ZVO}$, the educational process of the 
educational institution (A. Aleksyuk, A. Ayurzanain, O. Brazhnych, Yu. G. Golubova, R. Gurova, A. Zubko, N. Ippolitova, V. Manko, P. Podkasisty, O. Pekhota, N. Stadnyk, N. Sterkhova, O. Fedorova, B. Chizhevsky, etc.).

Thus, despite the significant development of the issue of the formation of leadership qualities of specialists, the problem of the formation of leadership qualities in future heads of preschool education remains insufficiently studied.

\section{CONCLUSIONS}

The research of the problem was carried out in three stages: at the first stage the theoretical analysis of the existing methodological approaches in philosophical, psychological, and pedagogical scientific literature, dissertations on the problem, as well as the theory and methods of pedagogical research was carried out; the problem, the purpose and methods of research are outlined, the plan of experimental research is made. At the second stage, the pedagogical conditions for the formation of leadership qualities of future leaders of preschool education institutions are determined and substantiated, which will contribute to the formation of their professional competence and require experimental testing of their effectiveness in the educational process of higher education institutions; experimental research work was carried out, the conclusions received during experimental work were analyzed, checked and specified. At the third stage the experimental work was completed, theoretical and practical conclusions were specified, the received results of the research were general and systematized.

In our study, we proceed from the fact that the definition of criteria and indicators, levels of leadership qualities of future leaders of preschool education combines the following structural components: motivational and value, combining a set of motives and values that determine the success and effectiveness of the leader; integrative-activity, based on which a set of organizational and communicative abilities that provide the ability of the head of the preschool education institution to integrate the teamwork of the staff of preschool education institutions; directional activity, which combines a set of decision-making skills and defining goals that ensure the purpose of the team; emotional-reflexive, which is determined by a set of abilities to recognize and manage their own emotions and the emotions of others, ensuring the ability of the head of the preschool institution to express itself as a standard.

As part of the implementation of the first pedagogical condition, the issue of development and formation of a set of professional motives in students, which are the basis for both educational activities and future professional success. Thus, for the implementation of the first pedagogical condition for the formation of leadership qualities was developed methodological support of practical classes with meaningful exercises to gain students a positive emotional experience of achieving artificially activated goals, increase their selfesteem and personal motivation to achieve, value orientations. As part of the implementation of the second pedagogical condition, the question of effective assimilation of knowledge by students, which should serve as a basis for the formation of their own concept of self-leader and a basis for a theoretical understanding of the principles of management. To implement the third pedagogical condition, review and problem lectures, seminars-discussions, and 
practical training sessions were held, the content of which was determined by the need to form certain applied leadership skills. The content of tasks is summarized to ensure that future leaders of the PEI perform the integrative function of a leader (exercises for applying skills in team building, conflict management, effective communication) and purposeful function of a leader (exercises for applying skills in coaching, decision making, time management). influence skills). The workshop organized in this way was aimed at forming integrative-activity and direction-activity components of leadership qualities. By performing the exercises, students had the opportunity to develop organizational and communication skills and the ability to set goals, plan, and make decisions accordingly. The next stage in the formation of team-building skills was to conduct practical classes, training. The next step was to consolidate the acquired knowledge and develop skills in effective communication through seminars-discussions on the topic: «Styles of behavior and communication in management». Thus, the content of tasks was summarized to ensure that future leaders of the PEI perform the integrative function of a leader (exercises for the application of skills in team building, conflict management, effective communication) and purposeful function of the leader (exercises for applying skills in coaching, decision making, time). -management, skills of influence). The workshop organized in this way was aimed at forming integrative-activity and direction-activity components of leadership qualities. By performing the exercises, students had the opportunity to develop organizational and communication skills and the ability to set goals, plan, and make decisions accordingly. During the implementation of the fourth pedagogical condition, we took into account the results of research that indicate the possibility of a positive experience in the development of emotional intelligence (B. Goloveshko, 2017). Thus, to implement the fourth pedagogical condition, practical exercises were developed that allowed students to analyze their own and others' emotions, identify various emotions, form knowledge about the manifestation of emotions through observation, manage their own and others' emotions. The implementation of pedagogical conditions took place in the following organizational forms: within the framework of achieving a certain pedagogical goal, problematic and review lectures were held, consolidation of acquired knowledge and skills development through thematic discussions, final skills formation took place during practical classes, pieces of training. Therefore, after the formative stage of the experiment, there is a positive dynamics of indicators of the formation of leadership qualities according to the components and criteria defined in the study.

\section{REFERENCES}

The proposed materials of the article are of practical value for heads of preschool education institutions, educatorsmethodologists, and future teachers of preschool education.

Adizes, I. (2009). Management Styles - Effective and Ineffective. Moscow: Alpina Business Books, 199 p.

Alfimov, D. V. (2010). The Content of the Phenomenon of «Leadership Qualities of the Individual. Pedagogy of Creative Personality Formation in Higher and General Education Schools. Zaporizhia, 11 (64), 44-51.

Akhmetova, M. N. (2004). Project Culture of the Future Teacher. School Technologies, 4, 210-218.

Batalova, T. V. (2004). Personal Determinants of the Process of Professional Development of Managers in Higher Education. Abstract PhD Thesis. Moscow, 20 p. 
Blanchard, K. (2008). Leadership: to the Pinnacle of Success. Saint Petersburg: Peter, 2008. 368 p.

Boyko, S. S. (2008). Curriculum of the Discipline «Methodology, Methods and Tools of Administrative Management» (for Masters). Kyiv: MAUP, 2008. Retrieved from: https://cutt.ly/XhcIWXo.

Vezhevich, T. E. (2001). Pedagogical Conditions of Development of Leadership Qualities of Students. Abstract PhD Thesis. Ulan-Ude, $20 \mathrm{p}$.

Volynets, Yu. O. \& Stadnik, N. V. (2019). Pedagogical Conditions of Formation of Leadership Qualities of the Future Teacher in the Conditions of European Integration. Professional Development of the Teacher in the Light of European Integration Processes. Hameln: InterGING, 66-84.

Voronina, K. O. (2009). Features of Studying the Level of Leadership Skills. Problems of General and Pedagogical Psychology: Collection. Science. etc. Institute of Psychology. G. S. Kostyuk Academy of Pedagogical Sciences of Ukraine. Kyiv, 11, 3. 99-107.

Gaponyuk, Z. G. (2008). Pedagogical Conditions for the Formation of Leadership Qualities in Students of Humanities Universities. Abstract PhD Thesis. Moscow, 24 p.

Goloveshko, B. R. (2017). Pedagogical Conditions of Formation of Leadership Qualities in Future Specialists in Administrative Management in Higher Educational Institutions. Abstract PhD Thesis. Kharkiv, 294 p.

Eliseev, O. P. (2003). Workshop on Personality Psychology. Saint Petersburg: Peter, 512 p.

Zeer, E. F. (2003). Psychology of Professions: a Textbook for University Students. Moscow: Academic Project; Ekaterinburg: Delovaya kniga, $336 \mathrm{p}$

Zorina, A. V. (2009). Pedagogical Conditions for the Formation of Leadership Qualities in University Students. Abstract PhD Thesis. Nizhny Novgorod, 25 p.

Ilyin, E. P. (2000). Psychology of Will. Saint Petersburg: Piter, 288 p.

Kalashnikova, S. A. (2010). Educational Paradigm of Professionalization of Management Based on Leadership. Kyiv: Kyiv. Univ. B. Grinchenko, 390 p.

Karpov, A. V. (2003). Psychology of Labor: Textbook. for Students. Higher Textbook Routine. Moscow: VLADOS-PRESS, $352 \mathrm{p}$.

Klishchevskaya, M. V. \& Solntseva G. N. (1999). Professionally Important Qualities as Necessary and Sufficient Conditions for Predicting the Success of Activities. Bulletin of Moscow University, 14(4), 61-64.

Lokshin, V. S. (2013). Formation of Leadership Qualities of Future Managers of Socio-Cultural Activities in the Context of the Process of Modernization of Higher Education. Spirituality of Personality: Methodology, Theory and Practice. Lugansk, 1(54), 109-120.

Lucin, D. V. (2006). A New Method for Measuring Emotional Intelligence: EmIn Questionnaire. Psychological Diagnostics, 4, 3-22.

Morgulets, O. B. (2012). Management in the Field of Services: Textbook. Kyiv: Center for Educational Literature, $384 \mathrm{p}$.

Morosanova, V. I. (1995). Individual Style of Self-Regulation in Arbitrary Human Activity. Psychological Journal, 4. 26-35.

Pilganchuk, A. \& Kuzmenko, V. (2012). Development of Leadership Skills in Future Psychologists. Humanities. Bulletin of Pereyaslav-Khmelnytsky State Pedagogical University named after G. Skovorody, 25, 412-415.

Pushkar, Z. M. \& Pushkar, B. T. (2017). Personnel Management: Textbook. Ternopil: Osadtsa Yu.V., 210 p.

Rozanova, V. A. (1999). Psychology of Management. Moscow, CJSC «Business School» Intel-Synthesis, 352 p.

Senin, I. G. (1991). Questionnaire of Terminal Values. Yaroslavl: NPC «Psychodiagnostics». Assistance Civil Initiative Foundation, $19 \mathrm{p}$.

Stadnik, V. V. \& Johna, M. A. (2003). Management: a Guide. Kyiv: Akademvydav, 464 p.

Fetiskin, N. P., Kozlov, V. V. \& Manuilov, G. M. (2002). Socio-Psychological Diagnostics of Personality Development and Small Groups. Moscow: Publishing House of the Institute of Psychotherapy, $490 \mathrm{p}$. 
Romanovsky, O. G., Ponomarev O. S., Ignatiuk O. A. (2011). Formation of Psychological Readiness of Future Specialists for Professional Activity. Kharkiv: Publisher Savchuk O. O.; NTU «KhPI», 336 p.

Shadrikov, V. D. (1982). Problems of System Genesis of Professional Activity. Moscow: Nauka Publishing House, 185 p.

Yakushko N. O. (2018). Theoretical Principles of Leadership Research in Domestic and Foreign Management Science. Governance, 1 (61), 25-29. Retrieved from: http://pa.stateandregions.zp.ua/archive/1_2018/7.pdf.

Hernez-Broome, G. \& Hughes, R. L. (2004). Leadership Development: Past, Present, and Future. Human Resource Planning, 27(1), 24-32.

Krasikova, D. V., Green, S. G. \& LeBreton, J. M. (2013). Destructive Leadership a Theoretical Review, Integration, and Future Research Aagenda. Journal of Management, 39(5), 1308-1338.

Lawson, K. (2009). Leadership Development Basics (Training Basics). ASTD Press, 128 p.

Selznick, P. (2010). Leadership in Administration: A Sociological Interpretation. Auckland: University of California Press, $162 \mathrm{p}$

Stale, E., Aasland, M. \& Skogstad, A. (2007). Destructive Leadership Behaviour: A Definition and Conceptual Model. The Leadership Quarterly, 18, 207-216. 


\title{
METAPHOR IN LEGAL COMMUNICATION
}

\author{
Joanna Osiejewicz, \\ University of Warsaw, Poland, \\ Associate Professor \\ https://orcid.org/0000-0001-8812-8276 \\ *j.osiejewicz@uw.edu.pl
}

\begin{abstract}
Even though metaphors might seem inappropriate to legal logical reasoning, they are quite a part of it. Although metaphor is non-literal and non-linear, nevertheless it is the essence of the modality of human thought. The way we think about law depends largely on metaphorical constructions. This means that we understand both the legal system as such and many formative ideas that operate in this system in metaphorical terms. The starting point for considerations is the cognitive theory of metaphor and its assumption of a constitutive nature of metaphor within our analytical framework. The aim of the article is to present the practical implementation of the theory in the field of legal communication. The author focuses on metaphorical construction of legal concepts, visualization of legal information and metaphorical legal reasoning.
\end{abstract}

Keywords: legal reasoning, visualization of law, cognitive metaphor theory, legal communication, free marketplace of ideas.

\section{INTRODUCTION}

Linguist George Lakoff and philosopher Mark Johnson developed the theory of how metaphors work in analyzing the world and what it means to humans (Lakoff, Johnson, 1980). Over the years their work has been widely cited in fields as diverse as clinical psychology, cognitive science, linguistics, literary studies, philosophy, and politics. The cognitive theory of metaphor has also become the subject of interest among legal theorists. Proponents of cognitive metaphor theory argue that metaphors are fundamental to how we understand and experience the world. According to Lakoff and Johnson, our ordinary conceptual system is metaphorical (Lakoff, Johnson, 1980a). Our thinking basically depends on metaphors. Consequently, human cognition is largely determined by the ability to recognize, understand, and use metaphors. This in turn suggests that metaphors define who we are. As a result, we "live" according to metaphors. Metaphorical thinking is therefore not just a linguistic tool, but a metaphysical principle of the highest order (Derrida, 1974). Metaphors are ways of describing or illustrating one concept by comparing it to another (Donlan, 2019). The relationship between the first concept and the second concept is attribution. By assigning the characteristics of the source concept to the target concept, we convey the meaning to the target concept, based on our own understanding of the attributes of the source concept. It is this account that conveys the meaning, not the words used. As a result, when we are faced with understanding a new or difficult concept, we try to cognitively associate an unknown concept with something we already know to make the new or difficult concept more 
understandable. Very often, perhaps almost always, this ascriptive relationship takes place without consciously thinking about it (Davidson, 2001). Lakoff and Johnson suggest (1980) that this metaphorical aspect of reasoning is cognitive. This means that metaphors are deeply ingrained in the way our brains work. We are fundamentally beings who understand concepts in metaphorical terms. Therefore, we systematically use inference patterns from one conceptual domain to infer another conceptual domain. Our convincing use of metaphor in analyzing and describing phenomena is because our bodies connect to the world in a way that recognizes and uses metaphorical relationships. From this point of view, these relationships are neurological in nature.

While it has been argued in science that metaphors do not have such a cognitive structure, the explanatory language model proposed by Lakoff and Johnson sounds convincing. According to Steven Winter (2001), following Lakoff and Johnson, a thought is not primarily linguistic and propositional, but embodied and imaginative. Metaphor is thus a natural phenomenon. Conceptual metaphor is a natural part of human thought, and linguistic metaphor is a natural part or feature of human language. In other words, we cannot isolate the metaphor from our conceptual schemas. We are metaphorical beings and everything we do has metaphorical consequences.

\section{PURPOSE, MATERIALS AND METHODS}

For the purposes of this discussion, I accept the assertions of Lakoff and Johnson (1980), and Winter (2001) that metaphorical reasoning is a fundamental cognitive aspect of human analytical processes. An interesting part of their claims is the constitutive nature of metaphor within our analytical framework, regardless of its possible neurobiological, social, or phenomenological causes. The relationship between how we analyze and use concepts and metaphorical reasoning seems to be confirmed. It does not appear that the metaphor is simply a linguistic tool used to illustrate complex issues. The ways in which people understand the world and give it meaning are driven by their conceptual systems. In fact, we could not understand the world and the events occurring there without any reference field. This field of reference allows us to deal with the phenomena we confront, giving them meaning. We experience the world in terms of our conceptual frame of reference and literally create our reality by relating phenomena to that field of reference (Lakoff, Johnson, 1980).

The claim that people always understand and experience one kind of thing in terms of another may seem a bit trivial, but it has significant consequences for legal communication. For example, we often conceptualize arguments between people in terms of conflict. The argument is that the metaphor of war is ubiquitous in our culture and probably in every other culture as well. We say, for example, "Your claims are indefensible", "I demolished his argument", or "They attacked every point in my argument". According to Lakoff and Johnson (1987), these are not just convenient and ingenious ways of describing arguments, but conceptual schemas that shape the way we think about arguments. The source concept (war) shapes our understanding of the target concept (argumentation). The construction of human reasoning follows this pattern.

According to Lakoff and Johnson (1987), there are many common metaphors that help us understand the world. They identified structural, orientation, ontological metaphors, 
and a whole host of other common metaphorical concepts that relate to realms that can be read to understand the world and our place in it. The common thread between these kinds of metaphors is that they all have consequences that emphasize and make certain aspects of our experience consistent. Metaphors create reality for us, especially social reality. The metaphor can therefore be a guide for future actions. Such actions will, of course, fit the metaphor. This, in turn, will strengthen the metaphor's power to make the experience coherent. In other words, the use of metaphor allows us to understand, but often it also limits our understanding. These limitations often result from culturally shared meanings. The most fundamental values in culture will be consistent with the metaphorical structure of the most fundamental concepts of culture. Since we understand some concepts in terms of other concepts, we are conceptually limited in what we can understand by what we already know in epistemological and cultural terms. These conclusions have important implications. For example, in areas such as law and politics, our reasoning determines metaphors that penetrate very deeply into cultural, economic, historical, and ideological identity and divisions. From a legal point of view, the cognitive metaphor theory enables a more humane and flexible design of law (Osiejewicz, 2020), and a more intelligible legal communication (Gawłowicz, 2018; Duminică, 2012).

\section{RESULTS AND DISCUSSION}

\section{Free marketplace of ideas}

The functioning of the metaphor in law can be extensively explained on the example of the doctrine of free marketplace of ideas, which dates to 1644. To this day this doctrine specifies the concept of freedom of speech and shapes international standards of freedom of expression. John Milton, the author of the first comprehensive defense of the freedom of speech, is considered to be the precursor to the doctrine of the "free market of ideas". In the treatise published on November 3, 1644, entitled "Areopagitica” Milton made the postulates considered today as the foundations of this doctrine: "free marketplace of ideas" and "self-righting process". The first element means allowing different views to be confronted freely, while the second one expresses the assumption that in such conditions the truth can demonstrate its superiority over falsehood (Biłgorajski, 2011). The treaty was a response to an Order passed by the Long Parliament, which included the control of printing: "that no book, pamphlet or newspaper shall be henceforth printed, unless the same be first approved and licensed by such, or at least one of such, as shall be thereto appointed" (United States. Congress, 1917).

Milton, addressing the Parliament, argued (2012) that censorship would not fulfill its task, would not stop scandalous and iconoclastic publications, and could only lead to the cessation of scientific activities, and thus the pursuit of the truth. Milton defined "truth" from the point of view of the course of a discussion. In his opinion, true opinion will remain in the "free market of ideas." All opinions rejected after a full, free investigation are false, bad, and silly. All accepted opinions are true, good and wise. There is no better test of truth than a process in which views are either adopted or rejected. So we are dealing here with an analogy to economic assumptions. Under the concept of a "free market", the value of goods is determined by the market. The truth, then, is only determined by the value that it is given 
by ideas and opinions in the intellectual "free market". The free-market test is thus a fully credible test. The "invisible hand of the market" ensures that the best products as well as the best ideas will win the competition.

More than 200 years after "Aeropagitika" was published, John Stuart Mill produced an essay "On Liberty" (1999), in which he presented the concept of "free marketplace of ideas". Mill also referred to the "free market of ideas" as a mechanism for seeking truth. The issue of truth is an important reference to freedom of speech. According to Mill, the opinion we conceal - considering its possible falsehood - may turn out to be true, or vice versa - the concealed lie may be partially true. Eliminating concealment can consequently increase the likelihood of converting falsehood into truth. Thus, Mill combined freedom of expression with a gradual rise in knowledge (Biłgorajski, 2011).

The "free market of ideas" doctrine found expression in the speech of US Supreme Court judge Oliver Wendell Holmes in the Abrams v. USA case (250 U.S. 616, 1919). This case concerned the application of the Espionage Act (1917) to five foreigners who had been convicted of engaging in unlawful acts designed to undermine the US government during the war. These acts consisted of writing and printing works that were considered disloyal, indecent, and offensive to a form of US government, expressing contempt, and intended to incite, provoke, and encourage resistance against the United States. The defendants contested these allegations. They argued that the First Amendment to the US Constitution allowed them to express their views openly and that the Espionage Act was therefore unconstitutional. In the opinion of Judge Clarke, the majority of the panel rejected this argument, saying that the words of the defendants could harm the US government. Consequently, the panel found that the Espionage Act constituted a constitutional restriction on the freedom of expression. Opposing this opinion, Holmes suggested that the view was downright dangerous (250 U.S. 616, dissent, 1919). He stated that it may seem perfectly logical to prosecute for expressing views. Whoever has no doubts about his/her own righteousness and strength, and wholeheartedly wants to achieve some result, transforms his/her aspirations into a legal form and eliminates all resistance. However, when people realize that the course of events has defeated more than one militant faith, they may come to a belief even stronger than that of the very basis of their conduct, namely that the most valuable good is easier to achieve by free exchange of ideas, that the best criterion of truth is the ability of an idea to be accepted under the conditions of free market competition, and that truth is the only basis on which we can safely pursue our intentions (Frankowski, Goldman \& Łętowska, 1998). In this brief discourse, Holmes elaborated what has been called the critical metaphor of the twentieth century (idealized cognitive model) of the First Amendment: the "marketplace of ideas".

The concept of Holmes' "free marketplace of ideas" clearly refers to the reflections on this subject formulated by Milton and Mill. However, it is Holmes who should be considered a precursor of using the doctrine in the process of applying the law in cases concerning freedom of expression (Winter, 2001). In the 1920s, the doctrine of the "free market of ideas" and the test of "clear and present danger" had another spokesman among the judges of the US Supreme Court. It was Judge Louis Brandeis. For the first time, the doctrine of the "free market of ideas" found a groundbreaking application in the judgment of the US Supreme 
Court in the New York Times Co. v. Sullivan (1964). The doctrine of the "free market of ideas", formulated by Milton and Mill, and then introduced into the jurisprudence by Holmes and Brandeis, also had a significant influence on the shaping of the standards of freedom of expression in Europe. A principle formulated in the judgement New York Times Co. v. Sullivan became a model for the judges of the European Court of Human Rights (Sadurski, 1998).

\section{Visualization of law}

Visualizations can help us understand complex information more easily. Although visualization techniques offer great potential to facilitate the communication of complex issues, visualizations are rarely presented in the legal field. "Text-like" character is a hallmark of the law. When visualizing complex legal issues, lawyers sometimes use simple diagrams to illustrate the legal relationships between different legal entities using letters, arrows, circles, and simple symbols (Burkhardt, 2018). Manuals also contain schematic representations which, for example, graphically depict the structure or functioning of organs or the relationship between different legal norms. However, apart from road traffic law, it is difficult to find illustrations to solve legal problems. Verbal expression dominates in teaching and jurisprudence.

The visualization of texts requires a multi-stage process (Braunschwieg, 2001). In successive phases, it is necessary to grasp the subject of the text, research its content and meaning, and look for relevant material that can be associated with it. Especially in the case of abstract texts that dominate legal regulations, for example, it is necessary to clarify the content and meaning. Only when there is an idea of what the image of this text could look like, the actual implementation takes place. These preliminary stages are usually not necessary when it comes to visualizing metaphors that already represent a certain image that only has to be materialized, i.e. fixed on a suitable medium (Brunschwig, 2002). Only in the absence of figurative associations should we consider how a metaphor can be represented by an image, for example the expression "mild judgment".

Visualizing a legal context is often more difficult. Because examples such as "the law expires" or "pending legal transaction" show that a context such as "law" or "legal transaction" is mostly abstract and therefore does not represent a concrete picture. Although such elements are not treated as part of a metaphor (Kleinhietpaß, 2005), their appearance in a visualization is necessary for two reasons: on the one hand to establish the legal context, on the other hand we are dealing with a metaphor only because it is triggered by the existing context. Since the context mainly consists of abstract terms, the simplest representation option is to include the term itself as a text element in the visualization. Although it is no longer an image in the strict sense, it still falls under the accepted definition of visualization of a metaphor (Brunschwig, 2002).

\subsection{Logical picture}

Many of the visualizations of metaphors fall under the concept of the logical picture (Araszkiewicz, Płeszka, 2015). Such visualizations are very schematic and rather ignore secondary elements. Their function is to represent real structures and relationships, concepts, theories, and ideas in a simplified way. They are also called arbitrary pictures, as 
due to their highly schematic nature they represent in this form something that is not actually visible (Alesandrini, 1984). This distinguishes them from images, which, like photography, are objects of the physical world. An example of a logical picture in the legal field is the visualization of the lineage according to tribes, which illustrates the legal relationships between relatives and by-laws in detail.

An example of a logical picture in the field of law is the visualization of the line of inheritance by tribes, which illustrates in detail the legal relations between family and relatives: the principle of representation in relation to the descendants of the testator - in place of the deceased descendant who is closer to the deceased, his/her escendants inherit, regardless of whether they are the heirs of the descendants in their place. In this context, one can also mention the popular visualizations of the "pyramid of norms" (hierarchy of legal acts) and the visualization of the pillar structure of the European Union (the so-called model of the Greek temple), which was established by the Maastricht Treaty (OJ C 191, 29.7.1992), and which has been the EU's showpiece and attribute for fifteen years. As these examples show, logical images are used in the legal field mainly to visualize legal theories or organizational structures. The visualized metaphor usually forms only a part of the overall picture.

\subsection{Non-visual metaphors}

Non-visual metaphors are those that relate to other sense organs than the sense of sight, such as the German expression "stille Gesellschaft" (silent partnership) and "voice" in elections as acoustic metaphors or the Polish word "przybicie" (slam - meaning an adjudication to the highest offer) as a tactile metaphor. The visualization of such metaphors undoubtedly requires artistic competence. It can also be aided using text fragments. There are also metaphors that reflect elements that are not perceived by the sense organ, such as internal properties that are based on the evaluation of certain behavioral patterns. An example of this is the word "gross", which is used in legal parlance in connection with an infringement ("gross infringement"). One can think of a visualization in the form of a representation of the circumstances under which this property is expressed. It can therefore be assumed that with the use of certain exhibition skills, all metaphors of legal language, also non-visual, can be visualized (Kleinhietpaß, 2005). It is only necessary to consider how this word, which has been transferred to the field of law, can be visualized and how the meaning or background of a metaphorical expression can be captured in the form of an image.

As for the legal context, the use of text is often necessary. However, since non-visual metaphors, unlike visual metaphors, do not provide a specific image, their visualizations cannot translate metaphors literally, but only in a slightly descriptive way, which often leads to only "indirect" visualization. In such a case, it can be assumed that the visualization often does not clearly reflect the expression on which it is based but allows for a multitude of interpretations. Moreover, the visual implementations of these metaphors by different people can differ significantly because, in contrast to visual metaphors, there is no uniform image form here, but a much freer choice of representation. This diversity of interpretability of nonvisual metaphors, which is burdened with the risk of misinterpretation by the recipient, can be eliminated through appropriate application of knowledge in the field of the art of picture interpretation (picture hermeneutics). However, knowledge in this area is not yet required 
to deal with law and it should be developed. A much easier way to avoid misinterpreting the image is to use visualized metaphors in direct association with the appropriate legal text explaining them (Baker, 2007). This eliminates most misinterpretations. It is of course impossible to completely avoid misinterpretation of the image content. For example, a correctly reconstructed visualization of the "binding effect of a contract" can nevertheless mislead the recipient into the mistaken assumption that it is possible to break free from the bondage without great effort: a vigorous movement is enough to loosen or loosen the shackles. For this reason, the visualization should consider all properties of the metaphorical expression and the legal text next to it should be as comprehensive as possible.

\subsection{Similarity of pictures}

Sometimes different metaphors can be represented by similar images (PhilippopoulosMihalopoulos 2016). Such a visualization applies in particular to metaphors that have the same core but express different legal aspects. In the case of the German expressions "Anhörung " (legal hearing at the court) and "Anhörung" (hearing of a law in the Bundestag), for example, both can be reduced to "hören" (hear). A visualization of these two expressions without reference to the image of the "ear" is difficult to imagine. They translate into an image in the same way, even though they relate to different legal realities. Even with expressions with a similar meaning, such as Polish "małoletni" (minor) and "nieletni" (not of age), there is a risk of confusion about the visualized metaphor. Although the Polish Penal Code (1997) uses the term "nieletni" (minor), there is no clear indication of how this term is to be understood. The definition of "małoletni" (minor) is contained in the Polish Civil Code (1964): according to Art. 10: a minor is a person who has not yet reached the age of 18. The term "nieletni" as defined in the Polish Penal Code has a narrower meaning. According to Art. 10, a person who is "not of legal age" is a person who has not yet reached the age of 17 at the time of the commission of a prohibited act, i.e. in principle the age required for criminal liability according to the provisions of the Polish Penal Code. The responsibility of minors for the offenses contained in the Polish Penal Code is regulated in the Polish Juvenile Criminal Procedure Act (1982). Only the representation of the different legal contexts of these expressions can differ from one another and thus lead to a clearer definition of a metaphorical expression. Also, regarding synonymous root phrases such as "complaint" and "vote in elections", the overlap of the visualizations due to the same root element (mouth, voice) is obvious. Moreover, there are expressions with a complementary representation, for example "employer" and "employee" or its German version "Arbeitnehmer" and "Arbeitgeber". Their visual representation calls for complementary activity: the giving subject requires the existence of the receiving subject. The combination of the action of "taking" and "giving" is an essential element of both metaphors and their common representation and needs a differentiation in the visualizations, since two different metaphorical expressions are visualized with the same pictorial component.

The easiest way to visualize seems to be simply materializing the image. However, such visualization is not always possible and would not always lead to a proper reconstruction of information. In such cases, it is possible, for example, to present a metaphorical expression in the form of an analogous term, possibly also through the circumstances that justify the 
linguistic statement or through the representation of associations with a given metaphor. The visual-verbal rhetorical figure is a combination of two types of signs, the effectiveness of which in communication depends on the tension between their semantic features. The cumulative effect of these signs is not simply summing them up, but rather their determining the relationship to each other.

The doctrine indicates several features of the language of law (Matulewska, 2008) that may have, primarily, a significant impact on the quality of visualization of legal expressions in the international context: archaisms, euphemisms, polysemy and homonymy, vulgarisms, metaphors, faux amis, neologisms, synonyms and quasi-synonyms, vague terms, legal definitions modifying the meaning, differences between colloquial and legal language. In the context of metaphors, cases of apparent unambiguity of a text seem to be of particular importance, as well as evident examples of its ambiguity. At the same time, ambiguity may result from the deliberate action of the author of the text or the legislator. The deliberate and lawful introduction of ambiguities allows for a broader interpretation of a text, e.g. a normative act, usually extending its scope of application. However, ambiguity may also appear unintentionally, as a result of lack of care in the preparation of the text or low competence in the field of the rules of legislative technique. The communication gaps caused by linguistic and cultural diversity can be overcome through visual communication as our minds perceive and comprehend the image and its meaning almost immediately without any visible process. Visual communication crosses borders and fills gaps in verbal language, leading to a better understanding of the information by the audience. However, in international communication, one should bear in mind the difficulties arising from various types of deficits in terms of the communicative potential of individual languages (Grucza, 2010). All languages are defective in many ways and it is not easy to express oneself unambiguously in them, in many cases it is not possible at all. This will cause numerous difficulties in expressing the concepts in individual languages in such a way that they can be properly interpreted by a recipient using a different language.

\section{Visual rhetoric}

Rhetorical figures are performative. They constitute a paradigm of visual thinking, which in today's image culture appears to be the most common representation of mental content. Visual thinking allows us to achieve a useful result effectively, quickly and intuitively, such as convincing a reader or listener. This communicative power of speech acts is an essential part of the human mind that expands interactively and is certainly possible in law. This materializes not only when a lawyer creates norms by means of drawings or interprets legal provisions as nomograms, but also when a judge devises his/her ruling by presenting oral reasons for a judgment. Visual thinking is a part of legal design as an aspect of information and communication technologies used in law. By adopting argumentation maps and graphical analysis of texts, the project aims to propose digital images and normative representations of a legal text based on visualizations to make the law more understandable and attractive to the public. By extending this perspective of visual law to lawyers, the preparation of legal documents supported by digital images becomes an evident aspect of the lawyers' argumentative technique, such as when composing graphic contracts. 
The rhetorical figures that can indicate with the help of an image that cannot be called an appropriate term include: visual-verbal comparison (a comparison that begins with verbal signs and continues with visual signs); visual-verbal analogy (relatum expressed verbally corresponds to a similar relatum expressed visually); visual-verbal metonymy (the relatum indicated by verbal signs is presented visually by signs remaining in some real relationship with it; e.g. cause instead of effect, tool instead of action, producer instead of product; visual synecdoche (relatum expressed verbally and visually is presented by the symbolizing part whole or vice versa); visual replacement (one visual sign replaced by another because of its formal features); visual-verbal parallelism (visual signs and verbal signs represent the same relatum); indirect association (one verbal sign from a sequence is illustrated by a certain sequence of characters which, in turn, lead to a different relatum of given verbal signs (Bonsiepe, 1985). In each case, it is about finding analogies, i.e. similarities between objects (known experience and unknown phenomenon) that share a common meaning.

Visuality not only affects individual utterances, but also manifests itself on the narrative level. Images replace words that would otherwise be required to explain the background, plot or subject matter of the cases under consideration. The power of visual-rhetorical means in legal discourse requires special attention to the ethical and professional responsibility of the author in order not to mislead or overwhelm the recipient (Murray, 2012). Visual effects successfully represent abstract concepts (such as emotions, states of being or mind) with or without accompanying text. Effective communication is possible when images are used to convey information that goes beyond language and cultural experience. Tales of heroism, sacrifice, injustice or corruption can be represented in pictures and used in the communication process. By the way of example, one would consider paintings of Jan Matejko (1878) and of Edward Dwurnik (2010), both entitled "Battle of Grunwald". Both paintings illustrate the same major international legal event, the Battle of Grunwald (1410), but convey different factual information and different emotional content. Whereas Matejko pictures splendor, great victory, and military strength of a state, in Dwurnik's painting, the place of the great battle of the Polish and Lithuanian armies with the Teutonic Order is taken by an ordinary brawl, in which the participants hit each other not only with sticks and truncheons, but also with crosses. In the chaotic struggle, it is difficult to identify the sides of the conflict, everyone fights with everyone, there is no military formation at all. The key moment of Matejko's composition is clearly marked and built around the figure of the deceased Master of the Order and the triumphant Prince Witold. Dwurnik's painting lacks such a dominant point or even a few highlighted points. Everything is equally important or just as irrelevant. The entire surface of the canvas is evenly and tightly filled with small figures, with no heroes among them. Historical figures are replaced by an anonymous crowd, a chaotic mass. The depiction of the fighting characters, however, speaks through allusions readable through signs, for example the cross. The comparison of these interpretations enables fruitful reflection on the established vision of the Polish history and native myths.

However, not every visualization of legal situation conveys metaphorical reasoning. A well-known example of visual rhetoric in legal proceedings is the letter from Bob Kohn, an American attorney who filed an amicus-curie lawsuit in the case United States v. Apple, Inc. (U.S. Appeals Court for the Second District, 2012) in the form of a five-page comic. The comic 
short story presented in an ongoing narrative shows the author's resistance to government action on the matter. The author claimed he filed it in lieu of his 25-page amicus curiae letter, which had previously been rejected by the court because it exceeded the page limit imposed by the court rules. It is noteworthy that this writing is essentially a summary of the key elements of the reasoning presented through the cartoon medium, rather than reasoning conveyed through visual rhetorical means. The form of drawing was thus not chosen because it made it possible to represent the most important elements of the argument through symbolic images. The characters in the cartoon - presumably the author himself and the young woman accompanying him - were only speaking aids to express the content of what is written. The drawing appears to express the attorney's desire to grab the court's attention rather than convey the content of the argument more effectively. American doctrine judged the letter to be unconvincing in its execution and unprofessional in its wording, as the party was mocking the court's five-page deadline for commenting on the case (Johansen, Robbins, 2015; Murray, 2016).

\section{CONCLUSIONS}

The way we think about law depends largely on metaphorical constructions. This means that we understand both the legal system as such and the many formative ideas that work in this system metaphorically. Although metaphor is non-literal and non-linear, nevertheless it is the quintessence of the modality of human thought. The way we think about law depends largely on metaphorical constructions. This means that we understand both the legal system as such and the many formative ideas that operate in this system in metaphorical terms. For example, the common legal terms "in the light of the law", "fruits of the poisoned tree", "pending legal transaction" and even "citizen of the European Union" are metaphors that are firmly established in the legal system.

Because legal reasoning is based on basic human skills, the cognitive theory of metaphor makes it more "human" and easier to understand. Legal terms are neither "literal, contextfree principles" nor "arbitrary or radically subjective social constructs". Legal rules are determined by the history, culture, norms, institutions, and practices of the respective community. However, they are also flexible and therefore can evolve in response to changes in social conditions, and thus facilitate the perception of legal information.

\section{REFERENCES}

Alesandrini, K. (1984). Pictures and Adult Learning, Instructional Science, 13, 63-77.

Araszkiewicz, M. \& Płeszka, K. (2015). Logic in the Theory and Practice of Lawmaking, Zurich: Springer.

Baker, L. (2007). The Art of Visualisation: The Art of Visualisation: Understanding Metaphors, International Journal of Disability, Development and Education, 54(2), 257-262, DOI: 10.1080/10349120701330628

Biłgorajski, A. (2011). Doktryna "wolnego rynku idei”: geneza, ewolucja oraz praktyczne zastosowanie, Z Dziejów Prawa 4, 111-134.

Bonsiepe, G. (1985), Retoryka wizualno - werbalna, Pamiętnik Literacki: czasopismo kwartalne poświęcone historii i krytyce literatury polskiej 76(3), 303-309.

Brief of Bob Kohn, Amicus Curiae, United States v. Apple, Inc., 889 F. Supp. 2d 623 (S.D.N.Y. 2012) (No. $12-$ cv-2826 (DLC)), http://media.wix.com/ugd/c526cc_439cb9e2d97049c38c04d5b9b43bf361.pdf 
Brunschwig, C. (2002). Visualisierung von Rechtsnormen. Zurich: Legal Design, Schulthess Juristische Medien.

Burkhardt, D. \& Nazemi, K. (2018). Visualizing Law - A Norm-Graph Visualization Approach based on Semantic Legal Data. Conference: The 4th International Conference of the Virtual and Augmented Reality in Education. At: Budapest, Hungary, DOI: 10.5281/zenodo.2543729.

Consolidated version of the Treaty on European Union, OJ C 326, 26.10.2012, p. 13-390.

Davidson D. (2001). Inquiries into Truth and Interpretation, Oxford: Clarendon Press.

Derrida, J. (1974). White Mythology: Metaphor in the Text of Philosophy, New Literary History, 6(1), 5-74.

Donlan, S. \& Mair, J. (2019). Comparative Law: Mixes, Movements, and Metaphors, Routledge.

Duminică, R. (2012). Intelligibility of the Laws - a Desideratum Difficult to Achieve by the Romanian Legislator. In the volume International Scientific Conference: Logos, Universality, Mentality, Education, Novelty. Iaşi: Lumen, 169-187.

Dwurnik, E. (2010), "Battle of Grunwald”, https://culture.pl/pl/dzielo/edward-dwurnik-bitwa-podgrunwaldem

Espionage Act of 1917, June 15, 1917. Courtesy of Library of Congress, https://iowaculture.gov/history/ education/educator-resources/primary-source-sets/americas-involvement-world-war-i/espionage

Frankowski, S., Goldman, R. \& Łętowska, E., Sąd Najwyższy USA. Prawa i wolności obywatelskie. Warszawa : OSCE 1998.

Gawłowicz, I. (2018). The Notion "Interest of the Legal Nature" in the International Court of Justice's Jurisprudence, Applied Linguistics Papers 25(4), 183-193.

Grucza, S. (2010). Główne tezy antropocentrycznej teorii języków, Lingwistyka Stosowana / Applied Linguistics / Angewandte Linguistik, 2, 41-68.

Johansen, S. \& Robbins, R. (2015). Articulating the Analysis: Systemizing the Decision to Use Visuals as Legal Reasoning, Legal Writing 20(57), 86-93.

Kleinhietpaß, C. (2005). Metaphern der Rechtssprache und ihre Verwendung für Visualisierungen, Berlin: Tenea Verlag.

Lakoff, G. (1987). Women, Fire and Dangerous Things: What Categories Reveal about the Mind, Chicago: University of Chicago Press.

Lakoff, G. \& Johnson, M. (1980). Metaphors We Live By (1980), Chicago: The University of Chicago Press.

Lakoff, G. \& Johnson, M. (1980a), The Metaphorical Structure of the Human Conceptual System, Cognitive Science, 4, 195-208.

Lakoff, G. \& Johnson, M. (1980b). Conceptual Metaphor in Everyday Language, Journal Of Philosophy, 77, 453-486.

Matejko, J. (1878), “Battle of Grunwald”, https://culture.pl/pl/dzielo/jan-matejko-bitwa-pod-grunwaldem Matulewska, A. (2008). Jakość przekładu prawniczego a cechy języka prawa. In: P. Nowak \& P. Nowakowski (eds), Język, Komunikacja, Informacja 3 (53-63), Poznań: Sorus.

Mill, J. S. (1999). O wolności, Warszawa: AKME 1999.

Milton, J. (2012). Aeropagitica, Warszawa: PWN.

Murray, M. (2012). The Great Recession and the Rhetorical Canons of Law and Economics, Loyola of Los Angeles Law Review 58, 615-638.

Murray, M. (2016). The Ethics of Visual Legal Rhetoric, LEGAL COMMUNICATION \& RHETORIC: JALWD 13, 107-155.

Order of the Long Parliament for the Regulating of Printing, 14 June 1643.

Osiejewicz, J. (2020). Transnational Legal Communication: Towards Comprehensible and Consistent Law. Foundation of Science, 25, 441-475. https://doi.org/10.1007/s10699-020-09655-3 
Philippopoulos-Mihalopoulos, A. (2016). Flesh of the Law: Material Legal Metaphors, Journal of Law and Society, 43(1), 45-65. DOI: 10.1111/j.1467-6478.2016.00740.x

Sadurski, W. (1998). Wolność prasy w systemie praw człowieka (wybrane zagadnienia). In: B. OliwaRadzikowska (ed.), Obywatel - jego wolności i prawa. Zbiór studiów przygotowanych z okazji 10-lecia urzędu Rzecznika Praw Obywatelskich. Warszawa: Biuro Rzecznika Praw Obywatelskich 1998.

Treaty on European Union, signed at Maastricht on 7 February 1992, OJ C 191, 29.7.1992, p. 1-112.

Treaty on the European Union, as signed in Maastricht on 7 February 1992, https://europa.eu/europeanunion/sites/default/files/docs/body/treaty_on_european_union_en.pdf.

United States. Congress (1917), Congressional Record: Proceedings and Debates of the Congress, vol. 55, part 2., Washington : U.S. Government Printing Office.

US Supreme Court judgement (1964), New York Times Co. v. Sullivan, 376 U.S. 254.

US Supreme Court judgement (1991), Abrams v. USA, 250 U.S. 616.

Ustawa z dnia 23 kwietnia 1964 r. - Kodeks cywilny, Dz.U. 1964 nr 16 poz. 93.

Ustawa z dnia 26 października 1982 r. o postępowaniu w sprawach nieletnich, Dz.U. 1982 nr 35 poz. 228.

Ustawa z dnia 6 czerwca 1997 r. - Kodeks karny, Dz.U. 1997 nr 88 poz. 553.

Wacławczyk, W. (2006). Koncepcja „wolnego rynku idei” w świetle współczesnych standardów wolności wypowiedzi. In: A. Florczak \& B. Bolechów (eds.), Prawa i wolności I i II generacji, Toruń: Wydawnictwo Adam Marszałek (pp. 176-177).

Winter, S. (2001). A Clearing in the Forest : Law, Life, and Mind, Chicago: University of Chicago Press. 
YOUNG WRITERS' CORNER 


\title{
LINGUISTICS IN LEGAL COMMUNICATION: LANGUAGE, COMMUNICATION, TEXT, LAW
}

\author{
Julia Pisulińska, \\ University of Warsaw, Poland, \\ student of Applied Lingustics: German and English \\ j.pisulinska@student.uw.edu.pl \\ Mentor: Joanna Osiejewicz, \\ University of Warsaw, Poland \\ j.osiejewicz@uw.edu.pl
}

Abstract. The paper encompasses such fields as language, communication, text, law in terms of legal communication. According to language, I try to define the language itself as well as the linguistic focusing mainly on accomplishments of De Saussure. Secondly, it was introduced the subject of communication and its history while taking into consideration the purpose of the paper: legal communication. Legal communication is based on juridical language and legal language. I discussed them and emphasised distinctions between them. This part of the paper, which I can describe as an introduction part, ends with an indication of the research on the field of legal communication.

The second part deals in general with communication and problems concerning this matter. I paid attention to the problem of communicativeness, because this matter is not as easy to be provided in legal communication as it seems to be. I moved on to the text as a part of legal communication, its main assumptions which by scholars are perceived as unable to be fulfilled and levels of interpretation this kind of text. This topic is followed by the issue of terminology which is the key to understand the text relating to law. Then I come back to the language, however, this time I point out the command of Polish language, its culture and the language of law stressing aspects regarding correctness. I decided also to include the subject of legal translation which apart from the issues mentioned above needs the specialised knowledge. The final part presents the main thoughts and my conclusions noticing the mutual influence between presented areas as well as the general need of expanding knowledge specifically in relation to language and law.

Keywords: legal communication, language, law, text,

The term "linguistics" comes from the Latin word "lingua", meaning language. Franciszek Grucza, who is considered to be the father of applied linguistics, perceives linguistics as a science dealing with human languages and distinguishes its two types: theoretical linguistics and applied linguistics (Grucza, 2017). Ferdinand de Saussure can be regarded as the precursor of linguistics itself, giving lectures on the subject which were later collected by his colleagues in the book, Course in General Linguistics. However, in the context of this work, the focus is on what defines this field, that is language. According to de Saussure, 
language is defined as a system of signs containing a signified and a signifier, meaning a signified and a signifying party. Over the years, the direction in which language is defined has changed considerably. An achievement that occurred in the 1970s may be revealing. Since then, a linguistic paradigm called communicationism has dominated. It was due to the concepts contained in the Prague School and generative-transformative grammar. It exceeded what was proposed by structuralism initiated earlier by de Saussure. He focused only on the sign-to-sign relation, whereas communicationism presents other relations based on the pragmatic and semantic aspect. The former shows the relations: sign-users and the psychocultural context of the sign, while the latter: sign-thought and reality. Thus, it is not only a study of the system, but also of linguistic communication and the text as a means of this communication. This does not mean, however, that the concept established earlier, i.e. structuralism, does not have its place in research and common consciousness. Both thoughts exist simultaneously creating a kind of ambiguity in linguistic research. This concerns the very notion of language, which can be defined in many ways (Gajda, 2004).

The concept of communicationism is extremely important in relation to the second issue discussed, that is communication. This act is realised if the goal, which in this case is in most situations the transmission of a message, is successfully realised and comes into being by means of language, writing, printing or the mass media (Kulczycki, 2012). Through them, it is produced in spoken and written form. The way information is exchanged is considered to be "primarily auditory, while the written form is secondary" (Olejniczak, 2018). The reason for this is that speech was the first to emerge and only later did people make use of symbols by transferring them onto writing materials. However, the fact is that communication has been around since ancient times and had its function long before the appearance of symbols (Kulczycki, 2012). Consequently, communication existed before the emergence of law, and generally of customary norms, which were the source of the origin of legal norms in antiquity. It played its role, also in the context of the later Mesopotamian, Hebrew or Greek law (Sójka-Zielińska, 2015). Already at that time, language, nowadays called legal language, was inextricably linked with communication in this field.

It is worth emphasising the distinction between juridical and legal language because, contrary to the common assertion, these two terms describe separate phenomena. In the last century, Bronisław Wróblewski attempted to define these terms. Juridical language is perceived as the language of normative acts issued by organisations with law-making competences. It belongs to the group of specialised languages, as a distinct community gathers around this particular system of signs. This means that the sender and the receiver are representatives of a group that has the skills to understand this code. By contrast, legal language is the one used by legal practitioners (Olejniczak, 2018). It includes the language of judicial and non-judicial practice, and jurisprudence (Gajda, 2004). Adam W. Olejniczak states that it should be intended as a bridge between juridical and colloquial language, between the legislator and the recipient of the law - the citizen (Olejniczak, 2018). It can be seen that juridical language functions as the superior language, while legal language is its derivative. The division may, however, go further than the one proposed by Wróblewski and encompassing only one central language and the other being its derivative (Olejniczak, 2018). Others that are also inseparable from law sometimes include: the distinctive 
language of legal rules and norms, the language of practice, doctrine (dogmatics), colloquial legal language (Brodziak, 2004). To this already extensive group should also be added the statements of representatives of higher state bodies, citizens, journalists, legal scholars, lawyers applying the law, other entities applying the law, school headmasters, chairmen of company boards, entities adjudicating in judicial and administrative proceedings, mayors, governors, etc. (Zieliński, 2004). These senders of messages are undoubtedly a very diverse group. It is a fact, however, that, for example, a journalist and a lawyer, although they probably formulate their statements in different ways, both use the language of law for this purpose. Nevertheless, there are doubts about this initial distinction, as well as about the much more specific one. It has not been resolved whether these languages can be understood as (de Saussure's distinction) "langue”, i.e. in linguistic terms (Brodziak, 2004).

It can be concluded that some linguistic issues concerning law, legal communication or various related areas have still not been clarified. However, there have been attempts to study the problems which constitute interesting scientific material, have still not been resolved, or the analysis of a given topic seems to be unsatisfactory to the researcher. The process of research on the language of law in Poland was particularly slow in the last century, and a real breakthrough occurred only at the end of the century. Jurisprudence is eager to refer to the matters concerning language, not limiting itself to strictly legal phenomena. This research to a large extent requires reference to the heritage of linguistics, which legal scholars are more and more willing to do (Zieliński, 2004). Linguists in particular, however, have expressed their interest in this area through analyses and theoretical texts (Śliwicka, 2018). This has only been happening recently. Previously, the scholars shunned the scientific study of this sphere, and if they produced analyses on this subject, they were often superficial and critical. Nowadays the main focus is on the communicative-linguistic sphere (Gajda, 2004).

The key to success in research may be the collaboration of the two communities. The two disciplines belong to the humanities and social sciences, which already provides a nucleus of common similarities. Stanisław Gajda mentions that "it would be worthwhile (to concentrate these interests in juridical language) by creating a certain organisational framework" (Gajda, 2004). It would make even more sense for this research to translate into everyday interaction between law and linguistics. Law is always linguistic in nature it is difficult to imagine that it would exist without words. It is believed that this function concerning a set of signs can be described as equally important as the regulatory function. In German, there is even a special expression referring to this: Sprachlichkeit des Rechts. In Poland, the research and development of this field has not allowed the creation of its own term, and perhaps it would be worth considering its domestic equivalent (Nieciecka, 2014).

A real problem that lawyers have been facing for many years is communicativeness. It is worth asking how the concept of communicativeness is understood. The word can be defined as "the ability to reach the recipient in the process of communication, to communicate; clarity, expressiveness". The key element of this definition is understanding. It is the absolute goal of the process of mutual communication. This result is achieved when both parties demonstrate linguistic competence, which is how statements are formed in a certain language, and communicative competence, which is based on demonstrating the 
ability to send and receive content (Chodun, 2009). The principle of relaying the clearest possible legal message to the public has long been on the agenda, but has largely remained unfulfilled (Gizbert-Studnicki, 2009). The blame for the current state of affairs lies on both parties. One party are lawyers, who often do not have the sufficient communicative and linguistic competence. There is no denying that they sometimes use legal language knowing that the recipient will not understand them. Then they focus on themselves, on what they want to convey, forgetting that the person who is obliged to read the message has no chance of doing so because of the characteristic way in which the statement is constructed and saturated with specialist terminology. A legal background would be necessary for laymen to understand what such a statement means. There is, however, a lack of such training in our country, and this state of affairs is not likely to change. The only solution therefore would be to make the message more comprehensible from a linguistic and communication point of view (Gajda, 2004). Such a proposal seems feasible, provided that both parties are willing to do so. Certainly, the intervention of linguists, who are most familiar with the language that is the source of the misunderstandings in this situation, could assist in this matter.

One type of communication, previously named secondary mode of communication, is text. It is used to establish legal norms (Lizisowa, 2009). Its essence is therefore to impose or enable a given course of action. It is created by legislators who decide on all the elements relating to the content and style of these written expressions (Malinowski, 2020). The value of legislative texts is assessed by whether it is characterised by following: precision, conciseness and unambiguity (Choduń, 2009). In his book, however, Tomasz GizbertStudnicki argues that text comprehensibility stands in opposition to these three pillars. Conciseness may be crucial when it comes to the interpretation of a legal text. When it is not maintained, there is a chance that the recipient would arbitrarily read the content, deeming some passages redundant. When the aim is for non-legal readers to understand the text, according to many examples, it automatically becomes longer. Another contentious issue is unambiguity, which is essentially linked to precision. Both these characteristics refer to the language of the law. This is because it is characterised by specialised terminology, which avoids ambiguity. For a text to be understood by a wide audience, it would have to resort to natural language, which creates ambiguities in terms of meaning at the lexical and syntactic level (Gizbert-Studnicki, 1986). The appropriate interpretation of the information encoded in written juridical language by many participants in the communication process is related to universality. It is important that the text reaches as many recipients as possible. Only then can it be considered to have been adequately understood, in accordance with what the author intended to convey. Moreover, it is ultimately expected that the recipient will not need to consult specialised sources of knowledge (Nieciecka, 2014). This would only hinder the layman's aspiration to learn about legal norms and create a negative attitude towards further contact with this field. In addition, the person whose task it is to produce legislation often fails to make clear their intentions, what they want to convey through a given text to the reader (Gizbert-Studnicki, 1986). It can therefore be deduced that achieving the ideal consensus between unambiguity, precision, conciseness and comprehensibility is a challenge for lawyers. 
With legal texts, also as with oral utterances, there is a demand for communicative competence, which the senders and receivers should possess. An essential feature of a legal text as an utterance is unidirectionality - the lawyer communicates the content to the person. The recipient should be aware that their task is to correctly interpret the information read out. This is done on two levels: descriptive and normative (Choduń, 2009). The former focuses on the world in which the written creation functions. This world abounds in things, events, behaviour. The recipient becomes acquainted with it in the course of literal reading of the text (Sarkiewicz, 2004). However, it would be wrong to treat this level as equal to a literary text. The common element connecting these two types of written expression is certainly the description of the world, but in the case of legal writing it does not contain such elements as action, persons, place, time, reasons or goals. There are only fragments reminiscent of a literary work. These include, among others, a description of the course of a trial or content focusing on the sequence of action, the person of the protagonist (Sarkiewicz, 2004). The normative level, on the other hand, deals with legal norms and often poses many difficulties for the layman (Jabłoński, 2020). In order to read it, the ability to correctly interpret the content is undoubtedly required (Sarkiewicz, 2004). The average citizen has problems with the reconstruction of laws and with the legal system in general (Choduń, 2009). Both levels function together. It is difficult to separate them from each other and to focus, for example, only on the literal reading. It is not true that first the literal meaning of a text has to be acquainted in order to perceive its normative character. This belief is based on the thesis that the descriptive account of legal norms can be understood as more primary. This refers to the question of the independent functioning of description. In order to read a text literally, it is not necessary to look at its normative character. Norms or directives, however, are inherent in the description of a certain reality (Sarkiewicz, 2004). People live though in a world in which most of them do not have a satisfactory knowledge of how to interpret a text correctly in normative terms.

In the general characterisation of the problem, it is also worth including the issues of terminology. Each law-related text contains terms that do not appear in everyday spoken language. Interestingly, even for some lawyers these terms may seem foreign. This is because law is divided into many sub-fields which are usually characterised by their own specific terminology. The main difficulties related to lexis that may be encountered by the recipient relate to semantic differences and the introduction of new, specialised terms. There are many words in law which are used by laymen. However, their knowledge is not sufficient to interpret the text correctly. It should be remembered that these terms change their meaning and, in their new context, refer specifically to law. There are many reasons and purposes for such transformations within existing terms. However, it should not be forgotten that they must be clear to the recipient and their use rationally justified. Sometimes it happens that those new meanings are a form of disrespect or lack of knowledge that a given expression has already been used in another way (Sobczak, 2017). In this matter, as in many others, the general knowledge of law, mentioned many times before, is also significant. New concepts are most often created in order to name specific institutions, which do not function within the common language (Matulewska, 2009). These terms usually enter the language through legal definitions, are presented in case law practice or legal science, and occur naturally in the Polish language. 
Many text-related concerns are raised by legal scholars' problems with language. The competence is divided into exemplary and satisfactory. The former applies primarily to the specialists. The sender-legislator and the recipient-interpreter characterised as experts in this field should have sufficient knowledge of the principles of legislative and interpretative technique and have a very good command of language (Malinowska, 2004). This is by no means only about the command of Polish, but also about its culture. Professor Hanna Jadacka, a linguist, stresses that the errors appearing in legal texts do not relate solely to grammar, but largely focus precisely on the culture of the mother tongue (Sobczak, 2017). There are many definitions of this concept. In general, there are three commonly accepted elements to which the culture of the Polish language refers: the value of the means of communication, correctness and cultural-linguistic activity. Linguists concerned with the culture of language determine what is considered a proper form or not (Kubicka, 2014). Correctness in legal texts must be maintained on two levels. The first concerns general language, the second, the Polish juridical language (Malinowski, 2020). This correctness is of great importance in law, although it often cannot be achieved, because it conflicts with the previously mentioned postulates of unambiguity, precision and conciseness. It is therefore necessary to ensure that the text is consistent with the Polish language, at the same time realising that the Polish language used there will not always be perfect.

However, linguistics is not only about the Polish language. More and more people are choosing foreign languages for their future. Professionals who use a sign system other than their mother tongue often choose translation as their career path. It may be general or specialised translation, or simultaneous or consecutive interpretation, and above all it may concern many areas. Legal translation is considered to be a specific type of the art of translation. It essentially requires knowledge of many areas and is therefore interdisciplinary. The core of this is, of course, the mother tongue, the knowledge of which is expected to be at a proficient level. Secondly, a translator must have a perfect command of the target language. The quality of legal translation may be determined by the translator's knowledge. Such a person needs to demonstrate a wealth of information within legal systems and general legal reality. Additionally, it is worth noting that jurists usually have knowledge of a specific field of law. A translator, even a specialised one, usually deals with various legal texts. The knowledge of translation studies, translation techniques may become helpful in transforming work from the source language to the target language. The minimum areas of knowledge that a translator should have are therefore four areas of science (Matulewska and Gortych, 2009). Unfortunately, even the extensive competences of a translator are not always enough to achieve success. Significant obstacles may be created by differences in the language of law. The source and target languages are usually based on different legal systems, which makes it difficult to translate many terms correctly. Difficulties may include the equivalence of the names of law enforcement agencies, the names of the judiciary, the names of court procedures, the names of juridical and legal documents, the names of legal institutions or common expressions, which are very common in law. There is no simple solution to this situation. The translator is obliged to check exactly what the meaning of a particular term is in the legal system. It is then worth consulting parallel texts. Legal writings often have established conventions, which makes it possible to compare them with others 
already existing in the target language (Kubacki, 2019). This requires additional work on the part of the translator, but there is no denying that, overall, translation itself is a complex process. In this case, the saying 'practice makes perfect' certainly applies.

Law lives in language and through language (Nieciecka, 2014). In conclusion, the special role of linguistics, and more specifically of linguists in each of the aspects presented, is what concludes this paper. In this paper, the lawyer-layman relationship has been mentioned in relation to the communication process. Both parties need linguistic and communicative competence, in which experts in the medium of speech are specialised, in order to convey and read the message properly. The linguistic heritage can contribute much to a better understanding between them. In the matter of the text, which has been discussed at length, communication proceeds unilaterally-the lawyer conveys the information necessary to the citizen. It is the lawyer who is responsible for ensuring that the text is unambiguous, concise, precise, correct and, above all, comprehensible. As has been emphasised, the legal professional often finds this a largely impossible challenge to meet. However, nothing stands in the way of trying to achieve the goal of finally making the recipients look kindlier on the texts in this field. This seems particularly important in terms of correctness. Lawyers' linguistic prowess is generally based only on what they have mastered throughout their lives. They do not pay attention to improve their knowledge of the rules and standards of the given means of communication, focusing primarily on the substantive content. Professionalism requires appropriate use of language, especially since their task is very often to create writing. The written form of expression is expected to have better formulated thoughts, to be structured, to follow grammatical, syntactic and semantic rules. It is also necessary to remember about the appropriate terminology, which will allow for precise expression of the content. "Verba volant, scripta manent" - spoken words fly away, written words remain. Lawyers' texts demonstrate their knowledge and skills. A specific form of legal communication, largely relating to texts, is translation. It would seem that the art of translating content from the source language into the target language depends primarily on the knowledge of both sign systems. This common misconception devalues the work of translators. It omits extremely important parts, such as the knowledge of a given field, in this case the knowledge of a vast and sometimes complicated law. The complexities of terminology and of the legal system itself require work and effort that are not always noticed.

Because of the many links between linguistics and law, it is worth considering sound linguistic education. In particular, it is important for specialist training to include the language of law. The familiarisation with language, however, should apply not only to lawyers, but to all citizens, since each person has to manage communication. In fact, a person never knows when he or she will be confronted with a problem relating to law. General education in this area would therefore be appropriate. These two fields cannot be separated from each other. Communicative competence in the field of law always requires two factors: the knowledge covering this science and the efficient use of language (Malinowska, 2004). 


\section{REFERENCES}

Brodziak, K. (2004). 0 lingwistycznym statusie języka prawnego. In: E. Malinowska, Język- prawospołeczeństwo (pp. 61-75). Opole: Wydawnictwo Uniwersytetu Opolskiego.

Choduń, A. (2009). Uwagi o komunikatywności tekstów aktów prawnych. In: A. Mróz, A. Niewiadomski \& M. Pawelec (Eds.), Prawo i język (pp. 127-131). Warszawa.

Gajda, S. (2004). Język administracyjno-prawny w perspektywie językoznawczej i prawoznawczej. In:

E. Malinowska (Eds.), Język- prawo- społeczeństwo (pp. 19-31). Opole: Wydawnictwo Uniwersytetu Opolskiego. Gizbert-Studnicki, T. (2009). Postulat jasności i zrozumiałości tekstów prawnych a dostęp do prawa. In:

A. Mróz, A. Niewiadomski \& M. Pawelec (Eds.), Prawo i język (pp. 37-48). Warszawa.

Gizbert-Studnicki, T. (1986). Język prawny z perspektywy socjolingwistycznej, Warszawa-Kraków: Państwowe Wydawnictwo Naukowe.

Grucza, F. (2017). Lingwistyka stosowana. Historia-Zadania-Osiagnięcia, Warszawa: Wydawnictwo

Naukowe Instytutu Komunikacji Specjalistycznej i Interkulturowej Uniwersytetu Warszawskiego.

Jabłoński, P. (2020). O ideologicznym poziomie interpretacji tekstu prawnego. Przegląd prawa $i$ administracji CXXII, 122, 39-54.

Kubacki, A. D. (2019). Podstawowe trudności w przekładzie tekstów prawnych. Artykuły po konferencji: Prawo i język prawa- współczesne dylematy.

Kubicka, E. (2014). Kultura języka w praktyce prawniczej- co?, po co?, jak?. In: D. Kala \& E. Kubicka (Eds.), Kultura języka polskiego w praktyce prawniczej (pp. 34-52).

Kulczycki, E. (2012). Teoretyzowanie komunikacji, Poznań: Wydawnictwo Naukowe Instytutu Filozofii UAM.

Lizisowa, T. M. (2009). Performatywne wypowiedzi prawne w aspekcie lingwistyki tekstu. In: A. Mróz,

A. Niewiadomski \& M. Pawelec (Eds.), Prawo i język (pp. 19-36). Warszawa.

Malinowska, E. (2004). Wzorce wypowiedzi urzędowych a ich realizacja. In: E. Malinowska (Eds.), Językprawo-społeczeństwo (pp. 143-150). Opole: Wydawnictwo Uniwersytetu Opolskiego.

Malinowski, A. (2020). Błędy formalne w tekstach prawnych, Warszawa: Wolters Kluwer Polska.

Matulewska, A. (2009). Problemy przekładu terminologii wieloznacznej występującej w polskich tekstach. In: A. Mróz, A. Niewiadomski \& M. Pawelec (Eds.), Prawo i język (pp. 85-94). Warszawa.

Matulewska, A. \& Gortych, K. (2009). Translacyjne problemy wyrażania modalności deontycznej w tekstach aktów normatywnych w języku polskim, angielskim i greckim. In: A. Mróz, A. Niewiadomski \& M. Pawelec (Eds.), Prawo i język, (pp. 65-78). Warszawa.

Nieciecka, K. (2014). Kilka uwag o problematyce komunikatywności tekstów prawnych. Studenckie Prace Prawnicze, Administratywistyczne i Ekonomiczne, 16, 107-124.

Olejniczak, A. W. (2018). Język prawny w prawie polskim. Ustawodawca dla profesjonalistów czy obywateli? In: A. Jakuszewicz (Eds.), Język i prawo (pp. 27-45). Bydgoszcz: Wydawnictwo Uniwersytetu Kazimierza Wielkiego.

Sarkiewicz, R. (2004). Koherencja tekstu prawnego w świecie koncepcji poziomowej interpretacji. In: E. Malinowska (Eds.), Język- prawo- społeczeństwo (pp. 49-60). Opole: Wydawnictwo Uniwersytetu Opolskiego.

Sobczak, K. (2017, July 17). Język narzędziem komunikacji prawodawcy ze społeczeństwem. Prawo.pl. Retrieved from: https://www.prawo.pl/prawnicy-sady/jezyk-narzedziem-komunikacji-prawodawcy-zespoleczenstwem,71259.html

Sójka-Zielińska, K. (2015). Historia prawa, Warszawa: Wolters Kluwer Polska.

Śliwicka, A. (2018). Język prawny i język prawniczy jako przedmiot badań językoznawczych i prawoznawczych w latach 1935-1999. Prace Językoznawcze, 20(3), 151-164.

Zieliński, M. (2004). Język prawny, język administracyjny, język urzędowy. In: E. Malinowska (Eds.), Językprawo- społeczeństwo (pp. 9-18). Opole: Wydawnictwo Uniwersytetu Opolskiego. 
ACADEMIA 


\title{
$13^{\text {th }}$ INTERNATIONAL SYMPOSIUM ON BILINGUALISM (ISB13) 9-14 JULY 2021, WARSAW, POLAND
}

\author{
Magda Żelazowska-Sobczyk, \\ $\mathrm{PhD}$, Assistant Professor, \\ University of Warsaw, Poland \\ https://orcid.org/0000-0001-7024-1246 \\ magda.zelazowska@uw.edu.pl \\ Piotr Romanowski, \\ PhD, Assistant Professor, \\ University of Warsaw, Poland \\ https://orcid.org/0000-0003-0520-1250 \\ p.romanowski@uw.edu.pl
}

The 13th International Symposium on Bilingualism was held in the capital of Poland, in Warsaw, from 9th to 14 th July 2021. The Symposium was organised by the Faculty of Applied Linguistics of the University of Warsaw. It gathered active researchers from the fields of sociolinguistics, psycholinguistics, educational linguistics, to name only a few disciplines. This year's conference was titled: 'Bilingualism in Flux'. The organisers intended to shed light on bilingualism as a dynamic and multifaceted phenomenon existing on a continuum. The in flux part of the theme was a twofold concept. First, it related to non-linguistic circumstances that foster not only diverse, but also transient bilingual communities throughout the world as we are currently witnessing new waves of migration influencing the linguistic status quo and enriching existing environments. Second, it pertained to the very processes taking place in language. Languages are, by nature, dynamic entities and as such are prone to changes. The fluctuating circumstances entail linguistic consequences reflected in the development of the second and further languages, cross-linguistic influence, language attrition, incomplete acquisition, and maintenance of heritage languages.

Due to the outbreak of the coronavirus disease, it was the first time when the conference had been organised in the online format. Speakers, organisers, and attendees scattered across six continents and hundreds of locations were connected via a video-conferencing tool and social media. Despite the delocalisation, the meeting retained many characteristics of a traditional conference: invited and contributed talks with follow-up questions and discussions, and poster sessions. However, unlike the traditional conferences, all attendees avoided air travel, accommodation costs, visa issues and took advantage of lowered registration rates. The impact on families was minimised as well, although participants in different time zones had to wake up early or stay up late. The first online ISB13 or e-ISB13 seems to be a resounding success, with 579 attendees: 188 PhD students and 391 established scholars. The conference brought together representatives from all over the world. Overall, 47 countries have been represented from 6 continents. The highest numbers of participants have been noted for: Poland (102), the United States (98), Germany (57), the United Kingdom (42), and Canada (36). 
The meeting was opened by the Dean of the Faculty of Applied Linguistics of the University of Warsaw, Chair of the ISB13 and a member of the ISB Steering Committee, Prof. Magdalena Olpińska-Szkiełko, PhD. During the opening session, important words of welcome were also given by the Rector of the University of Warsaw, Prof. Alojzy Nowak, PhD, and the Vice-Rector Prof. Sambor Grucza, PhD. They underlined the importance of languages and linguistics, including the topic of bilingualism and multilingualism in the current world. Welcome speeches were also delivered by the Chair of the Steering Committee, Prof. Christos Pliatsikas, PhD from the University of Reading and Prof. Ad Backus, PhD from Tilburg University, the former Chair of the Steering Committee (2017-2019). The mission, principles, and history of ISB were also presented by Prof. Elizabeth Lanza, PhD from the University of Oslo who held ISB8 in Oslo in 2011, Prof. Li Wei, PhD from the University College London, the founder of ISB, and Prof. Mila Schwarz, PhD from Oranim Academic College of Education, the secretary of the Steering Committee between 2015 and 2017.

Duringtheconference, four keynotelectureswere delivered by Prof.Agnieszka OtwinowskaKasztelanic, PhD (the University of Warsaw), Prof. Stephen May, PhD (the University of Auckland, New Zealand), Prof. María Luisa Pérez Cañado, PhD (the University of Jaen, Spain) and Prof. Christa Van Der Walt, PhD (Stellenbosch University, South Africa). There was also an opportunity for early-career scholars to present their research: Kamil Długosz, $\mathrm{PhD}$, (Adam Mickiewicz University), Aleksandra Olszewska, PhD, (the University of Florida, USA), Vincent DeLuca, PhD, (UiT-The Arctic University of Norway), and Anne BeattyMartinez, PhD, (McGill University, Canada). All the keynote lectures contributed to the discussion on the possibilities of developing further directions in the study of bilingualism and multilingualism. In addition, during the Symposium, there were 26 thematic sections and 27 open sections, during which a variety of aspects related to bilingualism and multilingualism, e.g. early second language acquisition \& learning, language acquisition, learning, teaching and transfer, perspectives of heritage languages, bilingual grammar (syntax, lexicon, and phonology), L3 development, translation \& interpretation, linguistics landscapes and language contact, code-switching, cross-linguistics influence, the relationship between bilingualism and the brain, bilingual families, cognitive and language impairments, as well as some psycholinguistics, sociolinguistics and pedagogical aspects were discussed. It is also worth noting that a great number of presentations was delivered by young researchers - PhD students.

The participants had a chance to familiarise themselves with the latest offers from such publishing houses as Brill, John Benjamins, Multilingual Matters, and Equinox. On the last day of the Symposium the business meeting was held, during which new members of the Steering Committee were selected as well as the incoming organiser of ISB14 was introduced. ISB14 will be held in 2023 in Sydney, Australia.

The Symposium created a valuable platform for sharing knowledge, experience, thoughts, discussing own research, results, and further implications. Participants could also debate on future avenues of research in the field of bilingualism and multilingualism. The meeting helped to establish international cooperation between scholars from all over the world. This partnership might benefit with different scientific projects, publications, conference presentations, and promoting research of Polish researchers worldwide. 


\title{
INTERNATIONAL INTERDISCIPLINARY SYMPOSIUM ON ART, SCIENCE AND TECHNOLOGY MEDEA, 2011-2021
}

\author{
Andreas Guskos, \\ Ph.D. in Fine Arts, Associate Professor, \\ Academy of Art in Szczecin, Poland, \\ https://orcid.org/0000-0003-2667-767X \\ andreasguskos@akademiasztuki.eu
}

One of the most exciting factors in sciences is their reciprocal overlapping. The International Interdisciplinary Symposium on Art, Science and Technology MEDEA is kind of the platform of cooperation, where the representatives of many different sciences participate year by year, each time increasing their research methods, broadening their scientific horizons and strengthening their relations with other academics from all over the world. This particular Symposium shows, how fruitful is cooperation between artists, lawyers, economists and engineers and how the society could respond to it as well as could benefit from it.

Each edition of MEDEA Symposium is concentrated around some artistic and/or cultural phenomenon and explores its legal, economic, cultural and many other aspects. Each edition of MEDEA Symposium has also its role model - a person, who's achievements in the given field are valuable and worth to explore and to follow. This kind of "leadership" highlights the importance of the development of social relations in the research area through particular personal dimension. A special quest of the first MEDEA Symposium in 2011 was Prof. Marcos Novak from the University of California in Santa Barbara, who visited Poland for the first time on this occasion. Professor Novak is known as an artist, nomad, theorist and pioneer of virtual architecture and of critical consideration of virtual space as architectural and urban place. He teaches and exhibits worldwide and originated several widely recognized artistic concepts including such of them like "transvergence", "liquid architectures", "habitable cinema", "allogenesis". Next editions of Medea Symposium hosted inter alia: Professor Lex Drewiński from Academy of Arts in Szczecin, talented designer and one of the most famous faces in poster's art in Poland; Professor George J. Papadopoulos, the late professor of the Faculty of Physics, National and Kapodistrian University of Athens, theorist of physics and also great philosopher; to name just a few of the distinguished guests of the Medea Symposium.

Each edition of MEDEA Symposium starts with the artistic exhibition and this is the transcendental ground, on which the whole atmosphere, scientific consideration and academic discussion of the Symposium is held.

The International Interdisciplinary Symposium on Art, Science and Technology MEDEA has been organized since 2011. To date, nine editions of the Symposium have been held:

- International Art-Science-Technology Workshop MEDEA 2011, Exploring the unvisible spaces, Szczecin, Poland, 2011.

- Second Art-Science - Technology Workshop MEDEA 2014, Towards a new Renaissance, Szczecin, Poland, 2014. 
- Third International Symposium on Art, Science and Technology MEDEA 2015, Back to the Future, Zakynthos, Greece, 2015.

- Fourth International Interdisciplinary Symposium on Art, Science and Technology MEDEA 2016, Summa Technologiae, Zakynthos, Greece, 2016.

- Fifth International Interdisciplinary Symposium on Art, Science and Technology MEDEA 2017, Physis | Morphosis, Heraklion, Greece, 2017.

- Sixth International Interdisciplinary Symposium on Art, Science and Technology MEDEA 2018, Gene | Meme | Techne, Thessaloniki, Greece, 2018.

- Seventh International Interdisciplinary Symposium on Art, Science and Technology MEDEA 2019, Broken Symmetry, Athens, Greece, 2019.

- Eight International Interdisciplinary Symposium on Art, Science and Technology MEDEA 2020, Events Horizon, Syros, Greece, 2020.

- Ninth International Interdisciplinary Symposium on Art, Science and Technology MEDEA 2021, Mutations, Thessaloniki, Greece, 2021.

The idea of the Medea Symposium is to create a context that would support the formation of connections on the border of science, art and technology. The Symposium includes panels: artistic (main panel), on science (PTA, International Symposium on Physics, Technology and Art), on legal sciences (ISLICS, International Symposium on Legal Implications of Cyber Society), on economic sciences (ITM, International Symposium on Information Tools in Management). In the frames of the collaboration with partners the following accompanying exhibitions were held: International Exhibition of Self-edition Posters Roller Poster, International Exhibition of Architecture, Interior Design and Applied Design Arch Inside, Exhibition of Polish Graphic Art transPRINT, International Exhibition of Electronic Art Syntopia, International Exhibition on Interactive Art Ex Machina.

The main institutions organizing the Medea Symposium are the Academy of Art in Szczecin and the Association for the Support of Art, Science and Technology Development MEDEA. The Symposium is organized in collaboration with the Western Pomeranian University of Technology in Szczecin, University of Szczecin, Gdańsk University of Technology, University of the Arts in Poznań, Silesian University of Technology, University of Zielona Góra, Polish Academy of Sciences in Poznań, the Władysław Strzemiński Academy of Fine Arts in Łódź, Łódź University of Technology, Pomeranian - Greater Poland Nanotechnology Forum, Mediations Biennale in Poznań, University of Athens, Aristotle University in Thessaloniki, Technological Institute of Ionian Islands, Higher School of Fine Arts in Athens, University of the Aegean, Athens Digital Arts Festival.

The International Interdisciplinary Symposium on Art, Science and Technology MEDEA has also its publishing achievements including the two interdisciplinary monographs and the number of the scientific articles in international journals. 

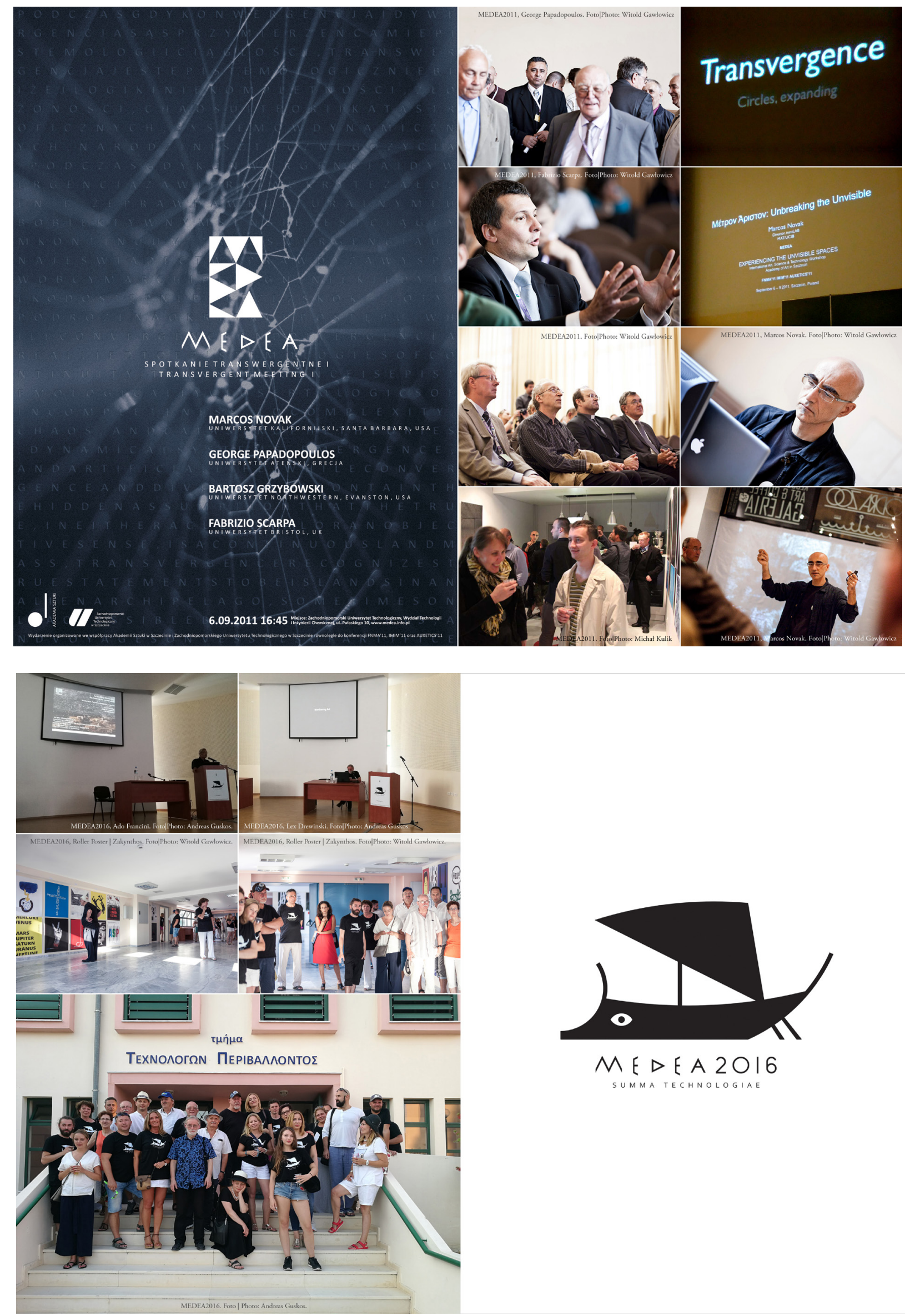